Florida International University

FIU Digital Commons

$11-9-2018$

\title{
A Mobile-Based Intervention for Obesity Prevention Among Female College Students in Saudi Arabia: A Randomized Controlled Trial
}

Abeer Hussain Alssafı

Florida International University, aalss001@fiu.edu

Follow this and additional works at: https://digitalcommons.fiu.edu/etd

Part of the Dietetics and Clinical Nutrition Commons, and the Nutrition Commons

\section{Recommended Citation}

Alssafi, Abeer Hussain, "A Mobile-Based Intervention for Obesity Prevention Among Female College Students in Saudi Arabia: A Randomized Controlled Trial" (2018). FIU Electronic Theses and Dissertations. 3877.

https://digitalcommons.fiu.edu/etd/3877

This work is brought to you for free and open access by the University Graduate School at FIU Digital Commons. It has been accepted for inclusion in FIU Electronic Theses and Dissertations by an authorized administrator of FIU Digital Commons. For more information, please contact dcc@fiu.edu. 


\section{FLORIDA INTERNATIONAL UNIVERSITY}

Miami, Florida

\section{A MOBILE-BASED INTERVENTION FOR OBESITY PREVENTION AMONG FEMALE COLLEGE STUDENTS IN SAUDI ARABIA: A RANDOMIZED CONTROLLED TRIAL}

A dissertation submitted in partial fulfillment

of the requirements for the degree of

DOCTOR OF PHILOSOPHY

in

DIETETICS \& NUTRITION

by

Abeer Hussain Alssafi

2018 
To: Dean Tomas R. Guilarte

Robert Stempel College of Public Health \& Social Work

This dissertation, written by Abeer Hussain Alssafi, and entitled A Mobile-Based Intervention for Obesity Prevention among Female College Students in Saudi Arabia: A Randomized Controlled Trial, having been approved in respect to style and intellectual content, is referred to you for judgment.

We have read this dissertation and recommend that it be approved.

Adriana Campa

Fatma Huffman

Changwon Yoo

Catherine Coccia, Major Professor

Date of Defense: November 9, 2018

The dissertation of Abeer Hussain Alssafi is approved.

Dean Tomas R. Guilarte Robert Stempel College of Public Health \& Social Work

Andrés G. Gil

Vice President for Research and Economic Development and Dean of the University Graduate School

Florida International University, 2018 
(C) Copyright 2018 by Abeer Hussain Alssafi

All rights reserved. 


\section{DEDICATION}

I dedicate this dissertation to my parents, who supported me reach the highest level of education. They have always supported me tremendously in my educational pursuits, no matter what my age or degree choice. This dissertation is also dedicated to

my amazing major professor Dr. Catherine Coccia, who never gives up on me. Without her patience, understanding, and support, the completion of this work would not have been possible. 


\section{ACKNOWLEDGMENTS}

I would never have been able to finish my project without the guidance, help, and support from many different people with their different ways. I would like to extend my appreciation especially to the following.

First, I would like to thank my major professor Dr. Catherine Coccia for all her support and encouragement. From the beginning, she had confidence in my abilities to not only complete a degree, but to complete it with excellence. After that, I would like to express my deepest appreciation to my dissertation committee members who have provided me extensive personal and professional guidance and taught me a great deal about both scientific research and life in general. Dr. Fatma Huffman since I met you in 2011 you have always encouraged and supported me. Dr. Adriana Campa, thank you for your amazing feedback and suggestions along with your willingness to serve on my committee. Dr. Changwon Yoo, thank you for your guidance and support throughout the research analysis.

I owe a lot to my parents, who encouraged and helped me at every stage of my personal and academic life, and longed to see this achievement come true. I thank my brothers and sisters for their support and good wishes. Also, I would like to thank my beloved fiancée, Mohammed Halawa. Though he came at the final stages of this journey, he has made it the best journey of my life. I love you all so much!

Above all, I owe it all to Almighty God for granting me the wisdom, health and strength to undertake this research task and enabling me to its completion. 


\section{ABSTRACT OF THE DISSERTATION \\ A MOBILE-BASED INTERVENTION FOR OBESITY PREVENTION AMONG FEMALE COLLEGE STUDENTS IN SAUDI ARABIA: A RANDOMIZED CONTROLLED TRIAL}

by

Abeer Hussain Alssafi

Florida International University, 2018

Miami, Florida

Professor Catherine Coccia, Major Professor

College students transitioning from adolescence into early adulthood may encounter new stresses, which may lead to unhealthy weight-related behaviors and weight gain. Students gain approximately 4-9 pounds during their first 2 years in college. Health behaviors in this population pose an increased risk because they tend to persist into adulthood. In Middle Eastern countries including Saudi Arabia, student obesity is on the rise. About $24 \%$ of female college students were overweight or obese in Saudi Arabia in 2015. This dissertation describes the development of a mobile intervention program using Instagram and a self-tracking app to minimize the risk of overweight/obesity in Saudi Arabian female college students by changing health behaviors, including increasing fruit and vegetable intake along with physical activity.

More than 100 students were randomly assigned to either the control or the mobile intervention group. Students in the intervention group were asked to participate in the study Instagram account by adding comments, likes, and sharing the post in an effort to 
increase social support for healthy eating and physical activity habits for 6 weeks. Each day was focused on 1 topic: general nutrition, fruits and vegetables intake, physical activity, social support, and self-efficacy. These topics were driven from social cognitive theory. Finally, students were asked to input their diet and daily activity into a selftracking app. Measures were taken three times during the study: pre and post intervention and at follow-up.

While the study was not long enough to detect the changes in body weight and physical activity, it did find that the intervention significantly increased fruit and vegetable intake. A small interaction effect was found between the two groups where the intervention group increased fruit and vegetable intake, while the control group decreased their intake of fruit and vegetables. Additionally, repeated measures ANOVA indicated significant differences between the groups in nutrition knowledge, family social support and exercise, and increase in eating and exercise self-efficacy. The promising results of this study provide support for further evaluation of the program. Future studies are needed to better understand the factors that serve as motivation and predict weight loss success among college students. 


\section{TABLE OF CONTENTS}

CHAPTER

PAGE

I. INTRODUCTION ............................................... 1

Obesity Rates in the Kingdom of Saudi Arabia.........................1

Obesity and Young Adults..........................................2

Significance of the Problem........................................... 3

Theoretical Perspectives..........................................4

Statement of the Problem...........................................5

Specific Aims and Hypotheses......................................6

II. LITERATURE REVIEW ........................................... 8

Obesogenic Behaviors in Young Adults................................8

Mobile-Based Intervention........................................ 8

Social Media in Young Adults......................................... 9

Instagram........................................................9

Social Media and Weight-Related Behaviors..........................10

mDiet app...................................................13

Mobile-Based Weight-Loss Apps/Self-Tracking Apps...................13

Summary and Conclusions.......................................16

III. METHODOLOGY .................................................. 17

Design.......................................................17

Sample.........................................................17

a) Recruitment......................................... 17

b) Sample Size........................................... 18

Randomization...................................................20

Intervention Development........................................20

Outcome Measures.............................................25

Statistical Analysis...............................................29

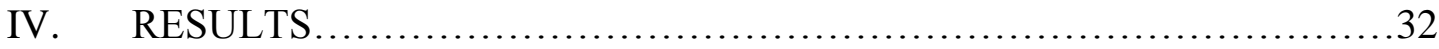

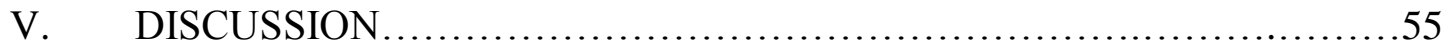

LIST OF REFERENCES ........................................66

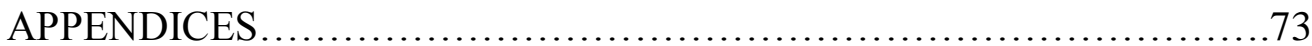

VITA............................................................. 


\section{LIST OF TABLES}

TABLE PAGE

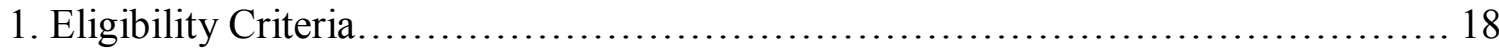

2. Key Constructs of Social Cognitive Theory.................................... 21

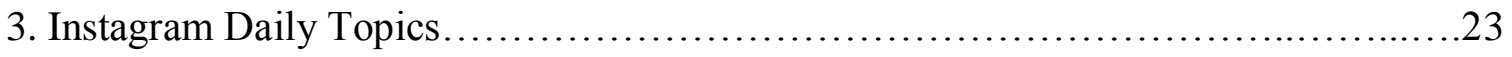

4. Incorporating mDiet into Social Cognitive Theory................................24

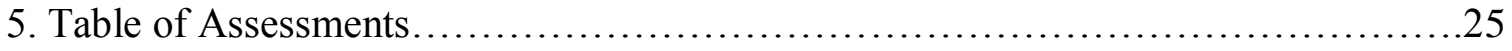

6. Statistical Analysis............................................................ 31

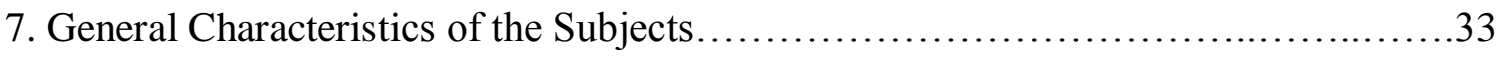

8. Related Characteristics of the Students at Baseline ....................................34

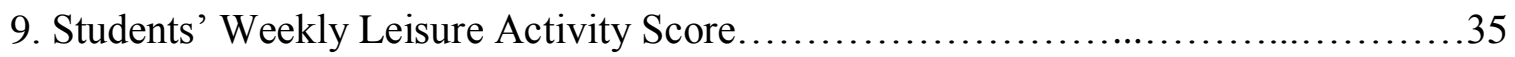

10. Descriptive Table by the Group Baseline "Mechanisms of Actions"...................35

11. Descriptive Table by the Group Baseline "Distal "Outcomes".............................36

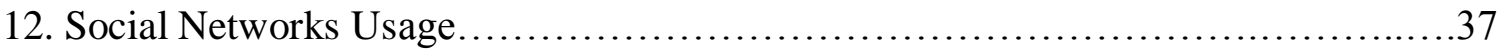

13. Completers VS Non-Completers in Demographics...............................38

14. Completers VS Non-Completers in Changes in Mediators based on SCT.............39

15. Completers VS Non-Completers in Changes in Outcomes...........................40

16. Student' Social Media Behaviors.............................................41

17. Correlation Matrix, Means, and Standard Deviations of Major Study Variable........42

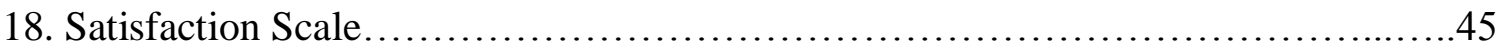

19. Repeated Measure ANOVA and Effect Sizes for Study Mediators.................50

20. Repeated Measure ANOVA and Effect Sizes for Study Outcomes (Pre-Post)........51 
21. Repeated Measure ANOVA and Effect Sizes for Study Outcomes (Post-Follow-

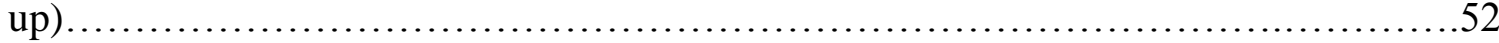

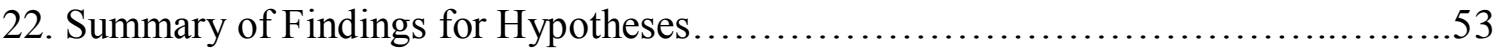




\section{LIST OF FIGURES}

FIGURE

PAGE

1. Integrating Social Cognitive Theory into the components $\ldots \ldots \ldots \ldots \ldots \ldots \ldots \ldots \ldots$

2. Flow-Chart of Study Participants........................................... 19

3. The Participants' Activity during the Study Period................................44 


\section{ABBREVIATIONS AND ACRONYMS}

$\begin{array}{ll}\text { APP } & \text { Application } \\ \text { BMI } & \text { Body Mass Index } \\ \text { BW } & \text { Body Weight } \\ \text { CVD } & \text { Cardiovascular Disease } \\ \text { CG } & \text { Control Group } \\ \text { FIU } & \text { Florida International University } \\ \text { IG } & \text { Intervention Group } \\ \text { KSA } & \text { Kingdom of Saudi Arabia } \\ \text { MMM } & \text { My Meal Mate } \\ \text { PA } & \text { Physical Activity } \\ \text { PNU } & \text { Princess Nourah bint Abdulrahman University } \\ \text { T2DM } & \text { Type 2 Diabetes Mellitus } \\ \text { RCT } & \text { Randomized Controlled Trial } \\ \text { SA } & \text { Waudi Arabia } \\ \text { SCT } & \text { Social Cognitive Theory } \\ \text { WH } & \text { Social Media } \\ \text { Whist Circumference }\end{array}$




\section{CHAPTER I \\ INTRODUCTION}

\section{Obesity Rates in the Kingdom of Saudi Arabia}

Obesity rates are increasing in the Kingdom of Saudi Arabia (KSA), and is one of the leading causes of lifestyle-related diseases such as cardiovascular diseases (CVDs), type 2 diabetes mellitus (T2DM), and some types of cancer. ${ }^{1}$ During the past 30 years, the number of overweight and obese individuals has tripled. ${ }^{2}$ In 2013, the Saudi Ministry of Health, in collaboration with the Institute for Health Metrics and Evaluation reported that obesity rates among adult women and men were $33.5 \%$ and $24.1 \%$, respectively, with a societal average of $28.7 \% .^{3}$

Adopting Western dietary habits involving overconsumption of high fat foods, sugar, salt, ${ }^{2,4}$ fast foods, sugar-dense beverages (e.g., sodas), and foods outside the home have increased the prevalence of overweight/obesity in KSA. ${ }^{5}$ Additional dietary changes such as decline in the intake of fruits, vegetables, whole grains, and legumes have increased the problem. ${ }^{2,4}$ In addition, people in KSA are not consuming enough fruits and vegetables, except for dates. ${ }^{6}$ It was reported that only $2.6 \%$ of Saudis aged 15 years or older met the United States Centers for Disease Control (CDC) guidelines. ${ }^{7}$ The CDC recommends 2 cups of fruits for adult men and women ages 19-30 years. It also recommends $2 \frac{1}{2}$ cups of vegetables for adult women and 3 cups for men ages 19-30 years. ${ }^{6}$ The World Health Organization (WHO) and the Food and Agriculture Organization (FAO) reported that consuming at least 21/2 cups of fruits and vegetables per day may prevent chronic diseases such as obesity and its comorbidities. ${ }^{8}$ 
In addition to the changes in dietary habits, a high prevalence (43.3-99.5\%) of sedentary behavior has been observed in KSA., ${ }^{9,11}$ Technological advances (cars, escalators, elevators) and an increase in screen time have contributed to more sedentary lifestyles. ${ }^{12}$ The World Health Organization (WHO) recommends that adults ages 18-64 years participate in > 150 minutes of moderate-intensity aerobic physical activities (PA) per week, > 75 minutes of vigorous-intensity aerobic PA per week, or an equivalent combination of moderate- and vigorous-intensity activity to reduce the risk of lifestyle diseases. ${ }^{13}$ However, many adults do not meet the WHO's PA guidelines. In 2013, an estimated 4.5 million (34.5\%) Saudi Arabian (SA) individuals > 15 years were physically inactive, while only 1.7 million (12.9\%) met the recommended levels of moderateintensity aerobic PA per week. ${ }^{14}$ An additional 3.4 million (25.8\%) practiced low levels of PA and only 3.5 million (26.8\%) Saudi Arabian adults met the recommended level of vigorous PA. ${ }^{14}$

\section{Obesity and Young Adults}

An important time for the development of health behaviors is during emerging adulthood, which is typically coupled with the transition to college..$^{15}$ Despite the importance of this time period for health behavior development, college is a time period full of new stresses, which often times lead to unhealthy weight-related behaviors and weight gain. ${ }^{16}$ In fact previous studies have reported that college students gain approximately 4-9 pounds during the first 2 years. ${ }^{17}$ In the Kingdom of Saudi Arabia (KSA), in 2015, Khalaf et al. reported that $23.8 \%$ of female college students were 
overweight or obese. ${ }^{18}$ Not consuming enough fruits and vegetables and insufficient physical activity are main leading reasons for the development of obesity among Saudi women. ${ }^{18}$ This is a critical health behavior, which requires interventions to prevent longterm obesity related health problems.

\section{Significance of the Problem}

Obesity is one of the leading causes of chronic diseases including diabetes and cardiovascular diseases. The Kingdom of Saudi Arabia has high rates of obesity in both the general population but also in young adults, females in particular. Despite the critical nature of health behavior development in emerging adulthood, coupled with high rates of obesity in KSA, cost-effective obesity prevention programs are lacking, especially for female college students. Therefore, there is an urgent need to develop a cost-effective lifestyle intervention for prevention and control of obesity that is targeted at female college students in KSA.

Mobile-based interventions have been suggested as a convenient and costeffective way to provide nutrition education for college students. ${ }^{19}$ Compared to face-toface methods, mobile-based interventions are potentially more convenient for both participants and providers, as mobile applications (apps) can be accessed at any point in time. Yet, there is insufficient evidence on whether social media (SM) or weight loss apps work for weight loss or obesity prevention. Thus, the purpose of the current study is to examine the acceptability and initial efficacy of a mobile-based intervention to increase fruit and vegetable intake and physical activity (PA) in female college students in KSA as an obesity prevention technique. 
The current study has several strengths. First, it focuses on an age and gender group, female college students, who has high obesity prevalence and are on their phones more than any other group. In 2016, it was reported that the average Saudi college student uses their phone $330 \mathrm{~min} / \mathrm{day}$, and duration was significantly higher in females. ${ }^{20}$ Second, this study utilized the social media (SM) Instagram, through which users may benefit from receiving health information, social support, and motivation. Instagram is one of the most popular social media apps in KSA. In 2016, it was reported that there were 3.1 million Instagram users in KSA and $90 \%$ of them were between the ages 18-44 years. ${ }^{21} \mathrm{~A}$ recent study reported that young adults use SM to seek health-related social support from people within their social network. ${ }^{22}$ Another study recognized that social interaction via SM could affect food choices and quantities among young adults. ${ }^{23}$ Third, the intervention developed and utilized in this study has a strong theoretical foundation based on Social Cognitive Theory (SCT). Finally, the current study is incorporating a self-tracking app, which has been shown to be beneficial in reducing body weight. ${ }^{24,25}$

\section{Theoretical Perspectives}

In order to guide behavioral change in the current study, Bandura's Social Cognitive Theory (SCT) was used as guide. This theory states that there is a reciprocal influence on behavior, which is influenced by intrapersonal factors (i.e., cognitive processes, affective processes, and biological events) and the physical and social environment. ${ }^{26}$ Self-efficacy, especially, is hypothesized to mediate the influence of intrapersonal factors that may influence learning and subsequent behavioral change. To increase self-efficacy, strategies should be aimed at improving goal achievement by 
increasing awareness, social support and self-efficacy. New technologies such as SM and self-tracking apps, as reviewed previously, may be capable of increasing self-efficacy to generate positive health behaviors in young adults (Figure 1).

Figure 1.

Integrating Social Cognitive Theory into the components

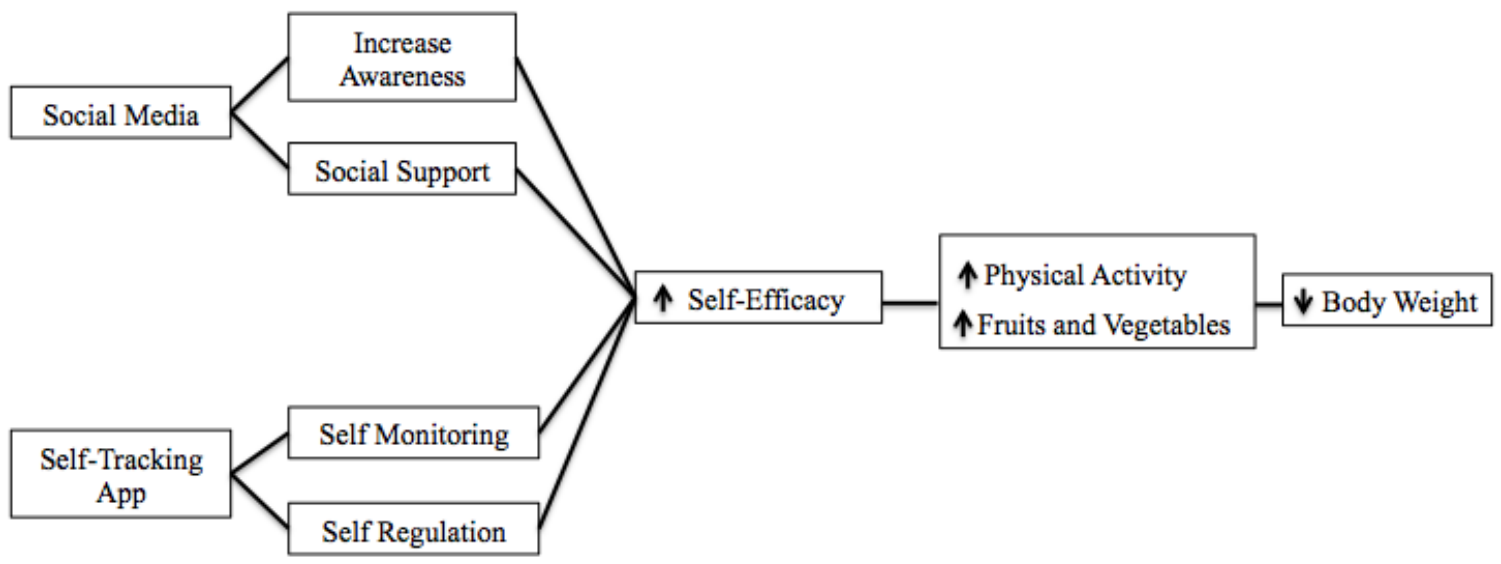

\section{Statement of the Problem}

Few researchers have looked at the effects of mobile-based interventions on preventing weight gain. Research needs to provide evidence-based endorsement for such interventions in changing behaviors among female college students. Thus, the overall purpose of this six-week randomized clinical trial (RCT) was to develop and examine the feasibility of an obesity-prevention program delivered by SM (Instagram) and a mobile self-monitoring app (mDiet) among female college students in KSA. The key behavior change theory that supports the study is Bandura's social cognitive theory, which has been previously used to improved diet and physical activity behaviors and resulted in a substantial body weight reduction. ${ }^{27}$ 


\section{Specific Aims and Hypotheses:}

1. Develop a SM+Tracking intervention based on social cognitive theory.

2. Examine the role of SM on college students eating behaviors.

3. Examine the implementation feasibility and promise of a SM+Tracking intervention to change college students obesogenic health behaviors (increase fruit and vegetable intake \& PA).

\section{- Feasibility}

○ Feasibility 1: Feasibility of the research design will be demonstrated by baseline recruitment of 100 students, assuming $60 \%$ retention (with complete data) at post-test and $50 \%$ retention (with complete data) at follow-up.

○ Feasibility 2: Feasibility of the intervention will be demonstrated through the number of likes, comments, and share in Instagram and strong satisfaction with intervention goals, content and format.

\section{- Hypotheses}

\section{The following hypotheses were tested:}

○ypothesis 1: There will be a difference between the control and the intervention group in terms of change mediators based on social cognitive theory. The intervention group will report higher nutrition knowledge, family and friend social support for eating and exercise, self-efficacy for eating and self-efficacy for exercise than the control group post intervention.

○ypothesis 2: A combination of social media and self-monitoring app will significantly increase fruits and vegetables intake among Saudi Arabian female college students. 
○ Hypothesis 3: A combination of social media and self-monitoring app will significantly increase physical activity among Saudi Arabian female college students.

○ Hypothesis 4: A combination of social media and self-monitoring app will significantly prevent weight gain among Saudi Arabian female college students. 


\section{CHAPTER II}

\section{LITERATURE REVIEW}

\section{Obesogenic Behaviors in Young Adults}

The transition to college usually happens between ages of 18 to 24 years. It has been recognized as a critical time for substantial and rapid weight gain as a result of poor

dietary habits. ${ }^{15,28}$ Many college students engage in unhealthy dieting, meal skipping, and fast food intake as a result of their hectic schedules and the newly gained freedom from parental influence. ${ }^{29}$ Studies have found that college students gain weight at an alarming rate,${ }^{30,31}$ equaling roughly 2 pounds per year. ${ }^{17}$ Another study reported that college students are likely to gain 4-9 pounds in the first 2 years of college. ${ }^{17}$ These years play an essential role in the development of health habits that continue into adulthood. ${ }^{32}$ As such, overweight/obese college students are at higher risk to become overweight adults ${ }^{33}$ and are at a higher risk for lifestyle-related diseases such as CVDs, T2DM, some cancers, and hypertension. ${ }^{34}$ Because of this, it is important to develop programs to encourage healthy weight-related behaviors for at-risk college students.

\section{Mobile-Based Intervention}

Compared to face-to-face methods, mobile-based interventions are considered cost-effective for weight-loss. Using mobile platforms to deliver health information may also be convenient for students because they can receive the intervention at any time using technology that has been integrated into their daily lives. Although limited, current studies have used SM and self-monitoring apps to improve weight-related behavior and have found positive results. For example, SM was shown to be effective in reducing body 
weight (BW) among college students ${ }^{19}$ and seemed to be a promising way to increase PA in other studies. ${ }^{35,36}$ Furthermore, several studies found that using self-monitoring apps led to BW reduction ${ }^{24,25,37-39}$, PA improvements, ${ }^{25,39}$ and increased fruits and vegetable intake. ${ }^{40}$ Despite these positive results, to date studies have not used SM and selfmonitoring apps together that are driven by nutrition educational theory to prevent obesity in a KSA population.

\section{Social Media in Young Adults}

Social media such as Instagram, Facebook and Twitter has become a popular communication platform especially among young adults ages $18-25$ years in KSA. ${ }^{41}$ This age group has been found to spend more time on SM than any other activity. ${ }^{42}$ It has been reported that they spend between 11 to 12 hours each day using technology and SM. ${ }^{43,44}$ In 2014, 89\% reported utilizing SM, 67\% accessed SM on their smartphones, ${ }^{45}$ and $79 \%$ were active SM users. ${ }^{46}$

\section{Instagram}

When examining social media Instagram (a popular SM app), it was reported that there were approximately 3.1 million users in KSA and 90\% of them were ages 18-44 years old in $2016 .{ }^{21}$ Instagram was launched in 2010 by Kevin Systrom and Mike Krieger. This is a free online mobile app that enables its users to take pictures and videos, then share them either publicly or privately..$^{50}$ Instagram has become popular in KSA with an estimated 8.8 million users in $2015 .{ }^{47}$ It was estimated that $90 \%$ of the users were between the ages 18-29 years. ${ }^{45}$ It has also been estimated that Saudis post an average of 12 photos on Instagram each week. ${ }^{47}$ It is clear that SM has become a normative aspect of 
young adult life. ${ }^{33}$ Interestingly, SM has become a crucial source of health information ${ }^{40}$ and young adults believe that SM could be used to improve behaviors. ${ }^{41} \mathrm{SM}$ interventions have been shown in some studies to be effective in reducing BW among college students ${ }^{19,36}$ and could be a promising method for increasing PA among female college students. ${ }^{35}$

\section{Social Media and Weight-Related Behaviors}

Recently, SM has become a crucial source of health information. ${ }^{48}$ Vaterlaus et al. ${ }^{41}$ found that SM could be a motivator to change weight related behaviors among young adults. These authors emphasize the importance of finding ways to use SM as a tool to distribute exercise and nutrition advice, along with inspirational quotes to motivate people to improve their lifestyles. ${ }^{41}$ Several studies have used SM to change health behaviors specifically related to weight loss.

In 2013, Napolitano and colleagues ${ }^{19}$ performed a randomized clinical trial (RCT) among 52 college students ages 18-29 years, most of whom were Caucasian ( $58 \%)$, and $32.7 \%$ of were sophomores. They assigned the students into the following groups:

Facebook, Facebook plus text messaging and personalized feedback, and control group (CG). The Facebook group received weekly handouts and podcasts via a private Facebook page along with access to healthy activities. In addition to the private Facebook page, the group that used Facebook, text messaging and personalized feedback received additional theoretically driven intervention targets through text messages; these were focused on goal setting, self-monitoring, and social support communications. The second group received a pedometer, Calorie King book, measuring utensils, a digital scale, daily 
text messages, and personalized feedback. At 4 and 8 weeks, the Facebook plus group experienced the greatest weight loss at $\sim 1.7 \mathrm{~kg}$ and $\sim-2.5 \mathrm{~kg}$, respectively. The changes in BW among the groups were statistically significant. Although the study was conducted with a small number of participants and only for a relatively short time period, it showed that Facebook, when combined with additional components such as self-monitoring, social support, and personalized goals was more effective in reducing BW than Facebook alone.

Another study examined the social networking website Twitter. In this study, however, Twitter was not effective in reducing BW in 96 overweight and obese adults ages 18-60 years. ${ }^{49}$ Subjects were randomly assigned to either a Podcast or Podcast+Mobile group. All study participants had access to a group-specific Podcast site. During the first 3 months, both groups received two Podcasts weekly (15 minutes each). During the second half, the two groups received 2 minipodcasts weekly ( 5 minutes each). Additionally, the intervention group was asked to download a FatSecret's Calorie Counter app and Twitter to their mobile device and encouraged to post at least daily to Twitter. The control group received a book with the calorie and fat contents of food to help in monitoring dietary intake. After 6 months, the researchers observed minimal weight changes in both groups $(\sim 0.25 \mathrm{~kg})$ without a difference between the groups.

In 2013, Valle et al. randomly assigned 66 young adult cancer survivors into two groups. ${ }^{36}$ They found that adding personalized goals to Facebook was more effective in reducing BW in young adult cancer survivors ages 21-39 years compared with just adding Facebook messages related to changing behaviors and social interaction. ${ }^{36}$ The majority of the participants were college graduates and non-Hispanic. The Facebook plus 
personalized goals group lost about $2.7 \%$ of their BW and had lost an estimated $2.1 \mathrm{~kg}$ compared to no significant weight loss in the Facebook without adding the other components $(-0.1 \mathrm{~kg})$. Differences in weight changes between groups approached significance $(\mathrm{p}=0.083)$. Moreover, The CG received Facebook messages related to PA every week, a Digi-Walker SW-200 pedometer, and had access to a private Facebook group page to socially interact. In addition to what the $\mathrm{CG}$ received, the $\mathrm{IG}$ received the same Facebook component, with additional access to a website offering tips on setting short-term and achievable physical activity goals; their Facebook page also had a moderator. After three months, increase in light PA was 135 min/week significantly greater in the IG relative to the CG. Interestingly, both groups in the study used Facebook and they both experienced significant increased in moderate-to-vigorous PA. This might be because the study was done among cancer survivors who were probably more motivated than healthy people.

Lastly, Cavallo and colleagues examined the efficacy of Facebook in conjunction with PA and a self-monitoring website in 134 undergraduate female students. ${ }^{35}$ In this study, $92 \%$ of participants were non-Hispanic, with $73 \%$ identifying as white, and $79 \%$ reported having parents who had attained college or higher levels of education. Subjects were randomly assigned to a control group (only received access to a PA-focused website) or an intervention group (received access to the same website with the addition to PA self-monitoring and Facebook group invitation using existing accounts). After 12 weeks, an increase in PA was found in the intervention group. Yet, no PA differences between groups were observed. The use of a self-report PA measure and short duration time could have affected the results. 


\section{mDiet app}

Thought there are a variety of self-tracking apps that target diet and PA, mDiet is the only self-monitoring app that targets Arab population. mDiet provides a database of thousands of Mediterranean foods. It lets users enter their current BW, goal BW, and goal rate of BW loss. It shows the users a daily and weekly report of their daily dietary intake.

\section{Mobile Based Weight-Loss Apps / Self Monitoring Apps:}

It has been reported that self-monitoring, regardless of the methods, can lead to weight loss success ${ }^{19,36,38}$ and improved PA. ${ }^{36}$ Today with the expansion of mobile health tracking apps, studies have been conducted to investigate whether these self-monitoring platforms have a role in improving health behaviors. Several studies have found positive results when self-tracking apps were part of a BW reduction program.

For instance, in 2015, Fukuoka et al. ${ }^{25}$ conducted a RCT in 61 overweight adults (>35 years of age) at high risk for diabetes. Participants were mostly female (77\%) and more than half of them were white non-Hispanics (52.5\%). The CG received pedometers and a National Institute of Diabetes and Digestive and Kidney Diseases brochure about pre diabetes. The IG used a mobile app modified from the original Diabetes Prevention Program, received a pedometer and were required to attend 6 in-person sessions. After 5 months, significant differences between the groups were observed. The IG had a greater reduction in $\mathrm{BW}(\sim-6.2 \mathrm{~kg})$, hip circumference, blood pressure, and intake of saturated fat. McCarroll et al. ${ }^{24}$ also indicated that a self-monitoring app could be beneficial in reducing BW. They included 50 overweight/obese cancer survivor non-Hispanic women ages 18-75 years and asked them to log in their food choices, exercise type and duration, 
and BW daily. After a month of using the "Lose It" app, significant loss were found in anthropometrics between pre- and post-intervention body weight (105.0 kg vs $98.6 \mathrm{~kg}$ ), body mass index (BMI) $\left(34.9 \mathrm{~kg} / \mathrm{m}^{2}\right.$ vs $\left.33.9 \mathrm{~kg} / \mathrm{m}^{2}\right)$, and waist circumference (WC) (108.1 cm vs $103.7 \mathrm{~cm})$.

Carter et al. ${ }^{37}$ and Hebden et al. ${ }^{39}$ were able to detect the efficacy of selfmonitoring apps in reducing BW. Carter and colleagues ${ }^{37}$ included 128 overweight adults ages 18-65 years and assigned them into three groups using the following resources, respectively: My Meal Mate (MMM) app, Weight Loss Resources website, and paper diary groups. Participants were mostly white (91\%) and female (77\%). All participants were provided access to an Internet forum for social support. The MMM group showed the greatest significant weight reduction after 6 months $(-4.6 \mathrm{~kg})$, when compared to the website group $(-3.3 \mathrm{~kg})$, but not when compared to the diary group. Similar findings were observed in a 12-week RCT pilot study among 51 female and male university students, ages $18-35$ years. ${ }^{39}$ In the Hebden et al. ${ }^{39}$ study, all participants received printed diet booklets. The IG received additional components: four text messages per week, four emails per week, and had access to smartphone apps and Internet forums. A significant reduction of $-1.6 \mathrm{~kg}$ was found in the IG. Though the 2 studies did not find significant differences in BW between the comparison groups, they found that using self-monitoring apps significantly improved BW. ${ }^{37,39}$

Another study by Laing and colleagues ${ }^{50}$ found significant weight loss resulting from the use of the MyFitnessPal app for 6 months among 212 overweight adults although they did report a minimal weight change. Participants were 18 years or older and were mostly white females. Participants in the IG were asked to use the app and they 
received a phone call from the researchers once a week to assist with any technical issues they may have experienced using the app. The participants in the CG were asked to choose any activity they liked to reduce their BW and were informed that they were participating in a weight loss app study, but were not given the name of the app being studied. After the intervention, the investigators asked the CG if they used the examined app anytime during the intervention. They found that the CG used the app during the study and that may have impacted the results.

Three studies looked at PA specifically as a result of the self-tracking intervention. ${ }^{24,25,39}$ Two found significant increases in PA, ${ }^{25,39}$ while one could detect the difference between the groups in the first week only. ${ }^{24}$ The studies' own self-reported apps found a significant increase in light intensity activity (34 min/day), ${ }^{39}$ increase in daily steps by $2551,{ }^{25}$ and time spent doing PA (182.3 min/day). ${ }^{24}$ All studies were of short duration, and included a small sample size.

In terms of fruits and vegetables intake, a pilot prospective study examined the efficacy of using the MyPlate app among 150 college students. ${ }^{40}$ The participants were full-time undergraduate students and mostly white (90\%). The intervention group received messages from the MyPlate app twice weekly. The control group received the exact same information in a mailed brochure at the beginning of the study. After 7 weeks, the intervention group experienced a significant increase in fruits and vegetables intake. Despite the positive results with the MyPlate app, dietary intakes were self-reported and the researchers did not validate food consumption. ${ }^{40}$ This could lead to under and/or overestimating the food intake. 


\section{Summary and Conclusions}

Based on our review of the literature to our knowledge this is the first study to examine the use of a mobile-based intervention in KSA, where the number of smartphone users is increasing. ${ }^{51,52}$ Without intervention or monitoring strategies, this population is experiencing a more sedentary lifestyle. The results from the literature reviewed indicate that SM and weight-loss apps are feasible options by which to promote positive weightrelated behaviors. In summary, all SM reviewed studies were done in the USA between 2011 and 2012. Of the included SM-based RCTs, two reported comparisons of BW,49, one reported comparisons of PA, ${ }^{35}$ and one reported comparisons of $\mathrm{BW}$ and $\mathrm{PA} .{ }^{36}$ While Twitter was not effective in reducing BW, Facebook was found to be effective among college students ${ }^{19}$ and approached significance among young adult cancer survivors. ${ }^{36}$ When comparing a Facebook group with non Facebook group, Facebook group increased PA. ${ }^{35}$ Yet, when comparing two Facebook groups with additional components, results showed increases in PA in both groups ${ }^{36}$ Future research is needed to learn more about the potential benefits and challenges associated with SM on young adult health behaviors. On the other hand, 7 articles were examined that used different self-monitoring apps. Changes in BW were observed with the use of MMM,,${ }^{37}$ Lose It, ${ }^{24,38}$ and studies' own self-monitoring apps..$^{25,39}$ Three studies looked at the efficacy of such apps in improving PA. ${ }^{24,25,39}$ The common study limitations included small or insufficient sample size and short duration (1-6 months). Thus, future studies with larger sample size are needed to test the potential use of such apps in changing individual's health behaviors. 


\section{CHAPTER III \\ METHODOLOGY}

The purpose of this study was to develop and examine the feasibility of an obesity-prevention program delivered by SM (Instagram) and a mobile self-monitoring app (mDiet) among female college students in KSA.

\section{Design}

Several reviewed mobile-based studies have used a RCT design and found positive results on improving BW and PA. ${ }^{4-6}$ Thus, the current study was a RCT with a 6week intervention period and 4-week follow-up. Based on a previous study that used SMbased intervention for 4-8 weeks gave significant BW reduction among college students. ${ }^{19}$ Additional studies used self-tracking apps found significant improvements in anthropometrics (BW, BMI, WC) ${ }^{24}$ in four weeks and increased fruit and vegetable intake in seven weeks. ${ }^{40}$

\section{Sample}

\section{a) Recruitment:}

Participants were screened and recruited from Princess Nourah bint Abdulrahman University (PNU), Riyadh, KSA. They were recruited for two weeks in February 2018. The university emailed the professors to facilitate the recruitment. This allowed the primary investigator to ask faculty members for permission to recruit within targeted classrooms. Recruitment was also done in the student center where students from different departments gather. Interested students provided their contact information to the primary investigator and were given a recruitment flyer (Appendix1). 
Prior to the intervention, the primary investigator emailed interested students to come to an information session for the study. At the information session students were provided with a more detailed description of the study, eligibility was assessed through a quick questionnaire, eligible students were asked to sign consent forms (Appendix 2\&3), and anthropometric measurements were recorded. This study approved at Florida International University (Appendix 4) and PNU Institutional Review Board (Appendix $5)$.

\section{b) Sample Size}

Students were included if they met the eligibility criteria. Inclusion and exclusion criteria are shown in Table 1. A total of 135 female college students who were eligible, of whom $103(72.3 \%)$ enrolled in the study and were randomized into two groups. Figure 2 presents flow chart of study participants through recruitment, intervention, and follow-up.

Table 1.

Eligibility Criteria

\begin{tabular}{ll}
\multicolumn{1}{c}{ Inclusion Criteria } & \multicolumn{1}{c}{ Exclusion Criteria } \\
\hline College students & Not meeting the inclusion criteria \\
$\begin{array}{l}\text { Have been weight stable (+/- } 5 \mathrm{Ibs}) \text { for the } \\
\text { past } 6 \text { months }\end{array}$ & $\begin{array}{l}\text { Lack of interest in improving } \\
\text { lifestyle behaviors }\end{array}$ \\
$\begin{array}{l}\text { Own a smart phone and are not using a } \\
\text { weight loss app on the phone }\end{array}$ & $\begin{array}{l}\text { Pregnancy or intention to become } \\
\text { pregnant within the next } 3 \text { months }\end{array}$ \\
Having access to the Internet & \\
\hline
\end{tabular}


Figure 2.

\section{Flow-Chart of Study Participants}

Recruitment

Randomization

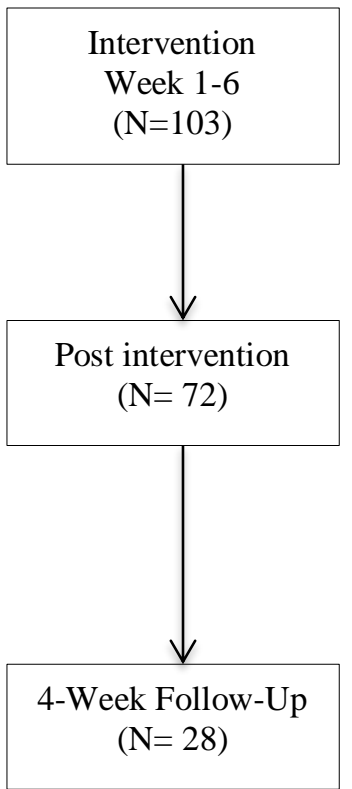

Female college students from Princess Nourah bint Abdulrahman University, Riyadh, KSA

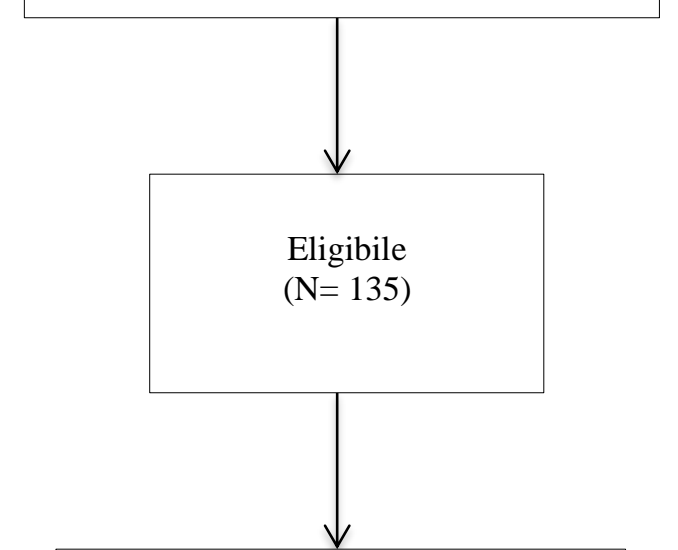

Returned the baseline questionnaire

$$
(\mathrm{N}=103)
$$

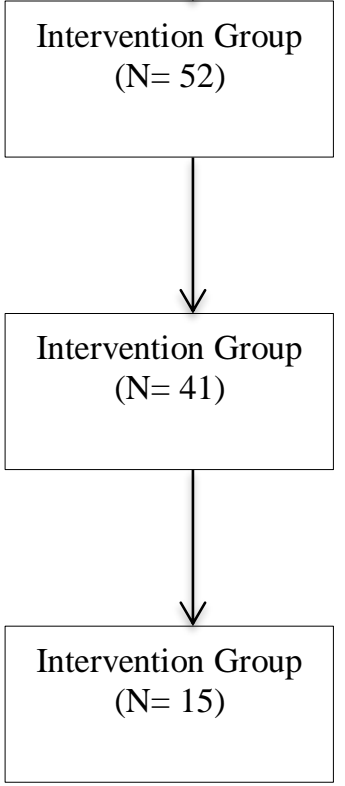

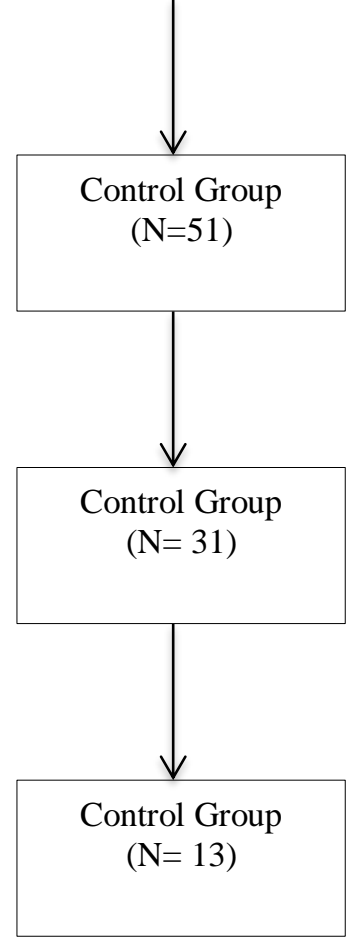




\section{Randomization}

Subjects who met the eligibility criteria and completed the baseline survey were randomly assigned to either a control group (CG) or intervention group (IG). A computer program was used to randomize the participants. The intervention started at the beginning of February 2018 and ended in the middle of March 2018. The intervention was 6 weeks long and followed by a 10-week follow-up. Participants met with the primary investigators at baseline and post-intervention to obtain anthropometric measurements. Follow-up data were collected via an online survey since the University was closed for summer vacation.

- Control Group:

The control group students provided consent to be in the study prior to randomization. Participants met the investigator twice during the study to measure their anthropometrics and to receive the survey link via email. The control group participants received fitbits (Appendix 6) when they came for the second session.

- Intervention Group:

Participants in this group received a direct message to inform them they were in the intervention group along with instructions for how to participate in the intervention. They also received fitbits when they came for the second session.

\section{Intervention Development}

\section{a) Program Theory}

Strategies based on social cognitive theory have been embedded into the study design aimed at increasing awareness, social support, self-monitoring, and self-regulation 
(Table 2). Goal setting, which is a SCT component was used in the study as a proxy for self-regulation.

Table 2.

Key Constructs of Social Cognitive Theory

\begin{tabular}{|c|c|c|c|c|}
\hline $\begin{array}{c}\text { SCT } \\
\text { Construct }\end{array}$ & Definition & $\begin{array}{l}\text { Intervention } \\
\text { Component }\end{array}$ & SM & $\begin{array}{c}\text { Self- } \\
\text { Tracking } \\
\text { App } \\
\end{array}$ \\
\hline $\begin{array}{c}\text { Increase } \\
\text { Awareness }\end{array}$ & $\begin{array}{l}\text { Emphasizes } \\
\text { awareness of the } \\
\text { different aspect of } \\
\text { the self, including } \\
\text { traits, behaviors, } \\
\text { and feelings }\end{array}$ & $\begin{array}{c}\text { Nutrition and PA } \\
\text { information } \\
\text { posted }\end{array}$ & $X$ & \\
\hline $\begin{array}{c}\text { Social } \\
\text { Support }\end{array}$ & $\begin{array}{l}\text { The perception that } \\
\text { others care and are } \\
\text { willing to assist an } \\
\text { individual; } \\
\text { involves being a } \\
\text { member of a } \\
\text { supportive social } \\
\text { network }\end{array}$ & $\begin{array}{l}\text { Provide social } \\
\text { support through } \\
\text { interaction with } \\
\text { friends and } \\
\text { participants }\end{array}$ & $X$ & \\
\hline $\begin{array}{c}\text { Self } \\
\text { Monitoring }\end{array}$ & $\begin{array}{l}\text { The ability to } \\
\text { regulate behavior } \\
\text { to accommodate } \\
\text { social situations. }\end{array}$ & $\begin{array}{l}\text { Promote data } \\
\text { input and } \\
\text { tracking }\end{array}$ & $X$ & $X$ \\
\hline $\begin{array}{c}\text { Self } \\
\text { Regulation }\end{array}$ & $\begin{array}{l}\text { Regulating and } \\
\text { monitoring } \\
\text { individual } \\
\text { behavior. }\end{array}$ & $\begin{array}{l}\text { App notifications } \\
\text { at specific times } \\
\text { to remind } \\
\text { students to track } \\
\text { their intake of } \\
\text { fruit and } \\
\text { vegetable }\end{array}$ & $X$ & $X$ \\
\hline $\begin{array}{c}\text { Self } \\
\text { Efficacy }\end{array}$ & $\begin{array}{l}\text { Confidence a given } \\
\text { individual feels } \\
\text { when engaging in } \\
\text { a particular } \\
\text { behavior. }\end{array}$ & $\begin{array}{c}\text { Help with } \\
\text { encouragement } \\
\text { and social } \\
\text { modeling } \\
\text { Help set realistic } \\
\text { goals }\end{array}$ & $X$ & $X$ \\
\hline
\end{tabular}




\section{Social Media: Instagram}

Instagram is the social networking tool that was utilized in this study due to its ease of use and popularity. Social support is thought to be a key component in behavioral weight-loss programs. ${ }^{53}$ Instagram can be used as a venue to deliver prompts from the program and allow subjects to support each other during their weight-loss efforts. In the current study, Instagram was used to deliver nutrition and PA information via posting pictures and/or videos.

Before the intervention started, a logo was created based on the purposes of the study "Challengeyourhealth42" (Appendix $7 \& 8$ ). In addition consistent with the social media formatting, the hashtag \#Challengeyourhealth42 was created to be used in the study in order for the group to study content and design. Instagram posts were developed and created explicitly utilizing Social Cognitive Theory constructs in order to promote behavior change in participants. The goals of the social media posts were to increase participant fruit and vegetable consumption and physical activity. Each day of the week the study focused on 1 topic from Sunday through Thursday. For a full list of topics and prompts please see Appendix 9. Sunday is the first day of the week in KSA. A day before the intervention, the primary investigator posted in the study Instagram account a welcome message, a reminder about respectful Instagram communications and the importance of maintaining confidentiality.

During the Intervention, the project account posted 1-2 pictures per day that participants were able to interact with by adding comments, liking, and sharing the post in an effort to increase social support for healthy eating and PA habits. Table 3 presents Instagram weekly topics. Every post was translated to Arabic. Students were asked to log 
on through their mobile device at least once daily to read messages posted and encouraged to "like," "share," or "comment." There was a challenge every week during 6 weeks. Whoever won the challenge received a \$25 gift card from Amazon. In addition, the investigators used "stories" feature within the Instagram app to remind the students to use the mDiet (self-tracking app), to provide additional social modeling of some investigator and students' health behaviors, to allow students to vote for the challenge winner and to post the challenge winner's picture.

Table 3.

Instagram Daily Topics

\begin{tabular}{ll}
\hline & Topic \\
\hline Sunday & General nutrition \\
Monday & Physical activity \\
Tuesday & Fruits and vegetables \\
Wednesday & Social support \\
Thursday & Self-regulation \\
\hline
\end{tabular}

\section{Self-Tracking App:}

In addition to Instagram, the IG received instructions by phone regarding how to access and download the mDiet. In the current study, participants were asked to set realistic weight maintenance or weight loss goals such as 0.5 to $2 \mathrm{lbs}$ per week. These goals allowed participants to enhance their self-regulation and set goals on a standard measure of the mDiet app. ${ }^{54}$ The self-monitoring feature of the app, consisting of recording dietary intake, PA and weight, has shown a strong correlation with weight loss. ${ }^{55}$ Moreover, a recent pilot study demonstrated that adherence to diet self- monitoring 
is higher among subjects using a smartphone app compared to subjects utilizing a paper diary. ${ }^{37}$ Table 4 explains how mDiet incorporates SCT components.

Table 4

How mDiet incorporates SCT components

\begin{tabular}{ll}
\hline Theory Component Targeted & \multicolumn{1}{c}{ mDiet } \\
\hline Self Efficacy & Provides feedback on daily walking \\
Self Monitoring & $\begin{array}{l}\text { Allows participants to monitor their fruits and } \\
\text { vegetables intake }\end{array}$ \\
Self Regulation & Allows setting weekly health behavior change goals \\
\hline
\end{tabular}

Using mDiet participants set a weight loss goal and self-monitored their daily fruit and vegetable intake. The intervention goals for consumption of fruit and vegetable were based on the $\mathrm{WHO} / \mathrm{FAO}^{8}$ or $\mathrm{CDC}^{6}$ recommendations. For the prevention of obesity, WHO/FAO recommends intake of a minimum of $2 \frac{1}{2}$ cups of fruit and vegetable per day. ${ }^{8}$ The CDC recommends 2 cups of fruits and $2 \frac{1}{2}$ cups of vegetables for adult women ages $19-30$ years. ${ }^{6}$ No other restrictions in fat or calories were emphasized by the intervention. Participants selected the fruit and vegetables they consumed from a database and logged items in an electronic food diary. Furthermore, they received motivational reminders via Instagram direct message or the story feature. Students were asked to take a screenshot from the mDiet app of their daily intake and send it via Instagram direct message to the study account. Those who did not send their daily report for three days received a phone call from the researcher to remind them. 


\section{Outcome Measures:}

In addition to the demographic variables (age, marital status, number of children, major, university level, and GPA) that were measured at baseline, several other measures were used in the current study. Table 5 represents the assessments used to evaluate intervention components.

Table 5.

Table of Assessments

\section{Intervention Weeks}

\begin{tabular}{|c|c|c|c|c|c|c|c|c|c|c|c|c|c|}
\hline \multirow{2}{*}{ Assessments } & \multirow[b]{2}{*}{ Screen } & \multirow[b]{2}{*}{ Baseline } & \multirow[b]{2}{*}{1} & \multirow[b]{2}{*}{2} & \multirow[b]{2}{*}{3} & \multirow[b]{2}{*}{4} & \multirow[b]{2}{*}{5} & \multirow[b]{2}{*}{6} & \multirow[b]{2}{*}{7} & \multirow{3}{*}{8} & \multirow[b]{2}{*}{$9 \quad 10$} & \multirow[b]{2}{*}{11} & \multirow[b]{2}{*}{ Assessment Tool } \\
\hline & & & & & & & & & & & & & \\
\hline $\begin{array}{l}\text { Informed } \\
\text { consent }\end{array}$ & & $\mathrm{X}$ & & & & & & & & & & & \\
\hline $\begin{array}{l}\text { Anthropometric } \\
\text { measurements } \\
\text { (Height, weight, } \\
\text { BMI, WC) }\end{array}$ & & $\mathrm{X}$ & & & & & & $\mathrm{X}$ & & & & $\mathrm{X}$ & $\begin{array}{l}\text { Height: stadiometer } \\
\text { Weight: digital scale } \\
\text { WC: standard tape }\end{array}$ \\
\hline Dietary Intake & & $\mathrm{X}$ & & & & & & $\mathrm{X}$ & & & & $\mathrm{X}$ & $\begin{array}{l}\text { Food Frequency } \\
\text { Questionnaire }\end{array}$ \\
\hline PA & & $X$ & & & & & & $X$ & & & & $\mathrm{X}$ & $\begin{array}{c}\text { Godin Leisure-Time } \\
\text { Exercise Questionnaire }\end{array}$ \\
\hline Satisfaction & & & & & & & & $\mathrm{X}$ & & & & & Likert scale \\
\hline Awareness & & $\mathrm{X}$ & & & & & & $\mathrm{X}$ & & & & & $\begin{array}{l}\text { General Nutrition } \\
\text { Knowledge Questionnaire }\end{array}$ \\
\hline Self-Monitoring & & & $\mathrm{X}$ & $\mathrm{X}$ & $X$ & $\mathrm{X}$ & $X$ & $\mathrm{X}$ & & & & & Screen shot \\
\hline Self-Regulation & & & $\mathrm{X}$ & $\mathrm{X}$ & $\mathrm{X}$ & $\mathrm{X}$ & $X$ & $\mathrm{X}$ & & & & & $\begin{array}{c}\text { Checking of participants' } \\
\text { progress and goals }\end{array}$ \\
\hline Social Support & & & $\mathrm{X}$ & & & & & $\mathrm{X}$ & & & & $\mathrm{X}$ & $\begin{array}{l}\text { The Sallis Social Support } \\
\text { Scale }^{56,57}\end{array}$ \\
\hline Self-Efficacy & & & $X$ & & & & & $\mathrm{X}$ & & & & $\mathrm{X}$ & $\begin{array}{c}\text {-Weight Self-Efficacy } \\
\text { Questionnair }{ }^{57} \\
\text {-PA Self-Efficacy } \\
\text { Questionnaire }^{58}\end{array}$ \\
\hline
\end{tabular}


Feasibility: At post intervention.

- Instagram: Feasibility was measured by the number of study-related likes on Instagram by participants similar to a previous study done among college students. ${ }^{19}$

- Satisfaction with Research Design: Participants were asked to rate their satisfaction with the intervention content, design and format using Likert scale responses $(1=$ complete disagree to $7=$ complete agree $)$. The Likert scale was developed by the investigators (Appendix 10).

Mechanisms of Action: Surveys were collected at the baseline, post intervention, and follow-up.

- Awareness (knowledge):

Nutrition knowledge was measured using General Nutrition Knowledge Questionnaire. ${ }^{55}$ The questionnaire was modified based on the topics that used in the study and reliability was $\alpha=0.8$ (Appendix 11). Moreover, nutrition knowledge was also measured using a questionnaire that was created by the investigator based on the study components with the reliability of $\alpha=0.8$ (Appendix 12). This questionnaire was given to both groups post intervention.

\section{- Social Support:}

Social support was measured using The Sallis Social Support Scale, which measure social support for $\operatorname{diet}^{56}$ and $\mathrm{PA}^{57}$ behaviors. The scale consists of 2 parts, in which 20-items assess the degree to which family (10 items) (Appendix 13) and friends (10 items) (Appendix 14) are sources of support 
specific to dietary behaviors. Part 2, consists of 26 items assess that degree to which family (13 items) (Appendix 15) or friends (13 items) (Appendix 16) are sources of support specific to physical activity .The scale scores ranged from 1 (never/not applicable) to 5 (very often). In the current study, the reliability of family and friends social support and dietary behaviors surveys are 0.6 (after deleting 1 item) and 0.6 (after deleting 1 item), respectively. While the reliability of family and friends social support and PA surveys are 0.8 .

\section{- Self-monitoring:}

Was measured by collecting screen shots taken by the participants of daily mDiet app reports, which represents their daily intake.

\section{- Self-regulation:}

Was measured by weekly checking of participants' progress and goals. The investigator posted in the Instagram story feature several times during the week to remind participants to continue entering their dietary intake in $\mathrm{mDiet}$ app.

\section{- Self-efficacy:}

- Weight self-efficacy questionnaire (Appendix 17): The questionnaire measures perceived control over food-related behaviors, and includes 20 different food-related situations such as (social events). ${ }^{57}$ Reliability in the current study were as follow: $\alpha=0.94$ at baseline; and $\alpha=0.9$ post follow-up.

○ PA self-efficacy questionnaire (Appendix 18): It assesses student's confidence to be active when facing with 5 common barriers (e.g., bad weather 
and lack of time). ${ }^{58}$ Reliability in the current study were as follow: $\alpha=0.9$ at baseline; and $\alpha=0.9$ post follow-up.

Distal Outcomes: Were collected from all participants at baseline, post intervention, and follow-up.

- Anthropometrics:

All measurements included (height in $\mathrm{cm}$, weight in $\mathrm{kg}$, and waist circumference (WC) in $\mathrm{cm}$, and $\mathrm{BMI}$ in $\mathrm{kg} / \mathrm{m}^{2}$ ) taken using standard techniques. Height was measured barefoot using a portable stadiometer to the closest $0.5 \mathrm{~cm}$, weight was measured without heavy clothes by a digital scale to the nearest $0.1 \mathrm{~kg}$, and $\mathrm{WC}$ was measured using the standard none stretchable tape taking the average of three readings.

\section{- Fruit and Vegetable Intake:}

Fruit and vegetable intake was evaluated with a Food Frequency Questionnaire (Appendix 19). Items related to fruits and vegetables were only used, which showed good reliability $\alpha=0.8$ at baseline in the current study.

\section{- Physical Activity:}

It was measured using the Godin Leisure-Time Exercise Questionnaire (GLTEQ), which evaluates the number of days and the average minutes per day over a period of 7 days that a participant engaged in strenuous, moderate, or mild PA (Appendix 20). ${ }^{60}$ This validated survey is applicable for measuring leisure time activity in a community setting and has been utilized in numerous studies. ${ }^{61-63}$. Reliability in the current study $\alpha=0.6$ at baseline. 


\section{Follow-Up (at week 10):}

All students received a link by email to complete the follow-up questionnaire and were asked to self-report their BW and WC. Students who came for post intervention measurements were given a measuring tape to self-measure their WC.

\section{Statistical Analysis}

\section{Primary outcome is change in BW}

The primary aim of this study was to determine the effect of Instagram and mDiet on improving BW, fruit and vegetable intake and PA. BMI was not used because this is a 6-week trial and reductions in BMI are not expected to be significant. Moreover, only one of the reviewed studies in the literature reported changes in BMI because most of the studies were of short duration.

\section{Power}

Based on a previous study used social media among college students, a reduction of $-1.7 \mathrm{~kg} \pm 1.6$ was considered statistically significant at a 4 -week intervention. ${ }^{4}$ After utilizing the G-Power program, the study needed a minimum sample size of 38 students (19 per arm). However, the current study enrolled 100 students (50 per arm) to account for $40 \%$ drop out rates at 6 -weeks and additional $10 \%$ drop out rates at 10-week follow up.

\section{Missing Data:}

In the current study, subjects who had completed data at post and follow-up were used in the analysis. The goal of the current study design was to determine the efficacy of 
the intervention treatment. Using intent-to-treat practices may not have provided much information about the effects of the program since participants who did not receive treatment would have been included in the analysis. To further examine participant dropout rates, a comparison between completers and non-completers will be conducted to examine differences in baseline characteristics.

\section{Statistical Analysis (Table 6)}

Subjects who had complete data at post and follow-up were utilized in the analysis. Data were described by means and standard deviations for continuous variables and percent for categorical variables. Demographic information that contained multiple categories such as marital status was dichotomized and the chi-square test of independence was used to assess differences between groups at baseline. A repeatedmeasures analysis of variance was used to assess changes over time among the continuous variables. Correlation Matrix was used to examine the correlation between multiple social media platforms and the main outcome. A $P$-value of 0.05 was used to indicate statistically significant differences. 
Table 6.

Statistical Analysis

AIM: To develop and examine the feasibility of a weight-loss intervention delivered by SM (Instagram) and the additive benefit of mobile self-monitoring app (mDiet) among female college students.

\section{Hypothesis}

H1: The intervention group will report higher nutrition knowledge, family and friend social support for eating and exercise, self-efficacy for eating and self-efficacy for exercise than the control group post intervention.

H2: A combination of the SM "Instagram" and the selfmonitoring app "mDiet" will significantly increase fruits and vegetables intake among SA female college students.

H3: A combination of the SM "Instagram" and the selfmonitoring app "mDiet" will significantly increase PA among SA female college students.

H4: A combination of the SM "Instagram" and the selfmonitoring app "mDiet" will significantly prevent weight gain among SA female college students.

\section{Independent and Dependent Variables}

Independent: Introducing Instagram and $\mathrm{mDiet}$

\section{Dependent:}

Nutrition knowledge, family and friend social support for eating and exercise, self-efficacy for eating and self-efficacy

Independent: Introducing Instagram and $\mathrm{mDiet}$

Dependent: Fruits and vegetables intake

Independent: Introducing Instagram and $\mathrm{mDiet}$

Dependent: PA score

Independent: Introducing Instagram and mDiet

Dependent: BW
Increasing physical activity compared with control group

Statistical Analyses

Increasing nutrition knowledge, family and friend social support for eating and exercise, selfefficacy for eating and self-efficacy

Increasing fruits and vegetables intake compared with control group

Primary analysis:

Repeated measures ANOVA.

Primary analysis: Repeated measures ANOVA.

Gaining fewer weights compared with control group

Primary analysis: Repeated measures ANOVA. 


\section{CHAPTER IV}

\section{RESULTS}

The purpose of this study was to develop and examine the feasibility of an obesity-prevention program delivered by SM (Instagram) and a mobile self-monitoring app (mDiet) among female college students as well as the effect of these apps on various outcomes including physical activity, fruits and vegetables intake, and body weight. The first section includes characteristics of the study sample. The second section includes the results of the six research hypotheses.

\section{Study Sample Characteristics}

Participants provided demographic information through self-report. Their demographic information is provided in Table 7. Hundred students ( $97 \%)$ were between the ages of 18-24 years old and 95 ( 92\%) had never been married, $7(\sim 7 \%)$ were married, and $1(1 \%)$ was separated. With regard to total number of children, only $3(\sim 3 \%)$ participants reported having one child and the rest $(n=100, \sim 97 \%)$ reported having no children. Participants were mainly studying science $(n=73, \sim 63 \%)$ and the majority were in level $4(n=42, \sim 41 \%)$. Moreover, $34(\sim 34 \%)$ of students had a GPA 3.5-3.99/5. Lastly, about half of the participants had normal BMI (about 47\%). 
Table 7.

General Characteristics of the Subjects

\begin{tabular}{|c|c|c|c|}
\hline & & $N=103$ & $\%$ \\
\hline \multirow[t]{2}{*}{ Age } & $18-24$ & 100 & 97.1 \\
\hline & $25-34$ & 3 & 2.9 \\
\hline \multirow{3}{*}{ Marital Status } & Single & 95 & 92.2 \\
\hline & Married & 7 & 6.8 \\
\hline & Separated & 1 & 1.0 \\
\hline \multirow[t]{2}{*}{ \#of children } & No children & 100 & 97.1 \\
\hline & 1 & 3 & 2.9 \\
\hline \multirow[t]{10}{*}{ Major } & $\begin{array}{c}\text { Business } \\
\text { Administration }\end{array}$ & 12 & 11.7 \\
\hline & Nursing & 5 & 4.9 \\
\hline & Community & 1 & 1.0 \\
\hline & Languages & 4 & 3.9 \\
\hline & Sciences & 37 & 35.9 \\
\hline & Social Services & 18 & 17.5 \\
\hline & Arts & 5 & 4.9 \\
\hline & $\begin{array}{c}\text { Computer and } \\
\text { Information Sciences }\end{array}$ & 14 & 13.6 \\
\hline & Art and Design & 4 & 3.9 \\
\hline & Education & 3 & 2.9 \\
\hline \multirow[t]{8}{*}{ University Level } & Level 1 & 6 & 5.8 \\
\hline & Level 2 & 18 & 17.5 \\
\hline & Level 3 & 7 & 6.8 \\
\hline & Level 4 & 42 & 40.8 \\
\hline & Level 5 & 4 & 3.9 \\
\hline & Level 6 & 8 & 7.8 \\
\hline & Level 7 & 6 & 5.8 \\
\hline & Level 8 & 12 & 11.7 \\
\hline \multirow[t]{7}{*}{ *GPA } & 5 & 2 & 2.0 \\
\hline & $4.75-4.99$ & 13 & 12.9 \\
\hline & $4.5-4.74$ & 17 & 16.8 \\
\hline & $4.0-4.49$ & 22 & 21.8 \\
\hline & $3.5-3.99$ & 34 & 33.7 \\
\hline & $3.0-3.49$ & 11 & 10.9 \\
\hline & Lower & 2 & 2.0 \\
\hline \multirow[t]{4}{*}{ BMI } & Underweight & 13 & 12.6 \\
\hline & Normal Weight & 49 & 47.6 \\
\hline & Overweight & 25 & 24.3 \\
\hline & Obese & 16 & 15.5 \\
\hline
\end{tabular}

${ }^{*} \mathrm{~N}=101$ 
Table 8.

Related characteristics of the Students at Baseline

\begin{tabular}{lcc}
\hline & N & Mean \pm SD \\
\hline Modified Nutrition Knowledge & 83 & $16.5 \pm 6.1$ \\
Social Support \& Eating: Family & 50 & $24.2 \pm 6.9$ \\
Social Support \& Eating: Friends & 49 & $25.7 \pm 6.4$ \\
Social Support \& Exercise: Family & 31 & $30.2 \pm 9.6$ \\
Social Support \& Exercise: Friends & 19 & $34.9 \pm 9.9$ \\
Self-Efficacy: Eating Habits & 41 & $72.0 \pm 20.2$ \\
Self-Efficacy: Exercise & 79 & $42.3 \pm 19.1$ \\
Fruits and Vegetables & 83 & $2.7 \pm 2.1$ \\
Only Fruits & 83 & $1.8 \pm 2.2$ \\
Only Vegetables & 84 & $.9 \pm 1.0$ \\
Physical Activity & 90 & $35.2 \pm 23.9$ \\
\hline
\end{tabular}

In Table 8 , the mean nutrition knowledge was $16.5 \pm 6.1$. The mean of the family and friends social support and eating habits score was $42.2 \pm 6.9$ and $25.7 \pm 6.4$, respectively. While the mean of the family and friends social support and exercise score

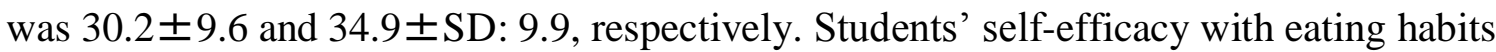
mean was $70.0 \pm 20.2$, while their self-efficacy with exercise mean was $42.3 \pm 19.1$. In terms of the main outcomes, students consumed an average of 2.7 servings of fruits and vegetables per day. They reported consumption an average of $1.8 \pm 2.23$ fruits and $.94 \pm 1.03$ vegetables per day. Moreover, according to GLTE Questionnaire, a scale of 24 units or more is considered active, 14-23 units is considered moderate active, and less than 14 units is considered insufficiently active/sedentary. In the current study, the mean PA level was $35.20 \pm 23.86$. This means that $67 \%$ of the students were getting the 
recommended amount of physical activity/week. Students' weekly activity scores are shown in Table 9.

Table 9.

Students' Weekly Leisure Activity Score

\begin{tabular}{lccc}
\hline & GLTE Score & N & \% \\
\hline Insufficiently Active/Sedentary & $<14$ & 22 & 22.4 \\
Moderately Active & $14-23$ & 12 & 11.7 \\
Active & $>24$ & 69 & 67.0 \\
\hline
\end{tabular}

Table 10.

Descriptive Table by Group at Baseline "Mechanisms of Actions"

\begin{tabular}{|c|c|c|c|c|c|c|}
\hline & \multicolumn{2}{|c|}{ Intervention Group } & \multicolumn{2}{|c|}{ Control Group } & \multirow[b]{2}{*}{$\mathbf{F}$} & \multirow[b]{2}{*}{ Sig. } \\
\hline & $\mathbf{N}$ & Mean \pm SD & $\mathbf{N}$ & Mean \pm SD & & \\
\hline $\begin{array}{l}\text { Modified Nutrition } \\
\text { Knowledge }\end{array}$ & 44 & $15.36 \pm 6.97$ & 39 & $18.15 \pm 4.56$ & 4.53 & .08 \\
\hline $\begin{array}{l}\text { Social Support \& } \\
\text { Eating: Family }\end{array}$ & 20 & $27.00 \pm 8.09$ & 27 & $28.89 \pm 6.64$ & .77 & .38 \\
\hline $\begin{array}{l}\text { Social Support \& } \\
\text { Eating: Friends }\end{array}$ & 24 & $25.50 \pm 7.09$ & 25 & $25.92 \pm 5.70$ & .05 & .82 \\
\hline $\begin{array}{l}\text { Social Support \& } \\
\text { Exercise: Family }\end{array}$ & 19 & $28.63 \pm 8.42$ & 12 & $32.58 \pm 11.06$ & 1.27 & .27 \\
\hline $\begin{array}{l}\text { Social Support \& } \\
\text { Exercise: Friends }\end{array}$ & 14 & $\begin{array}{c}37.21 \pm 10.3 \\
3\end{array}$ & 5 & $28.40 \pm 4.72$ & 3.29 & .09 \\
\hline $\begin{array}{l}\text { Self-Efficacy: } \\
\text { Eating Habits }\end{array}$ & 20 & $\begin{array}{c}73.70 \pm 18.8 \\
2\end{array}$ & 21 & $70.42 \pm 21.76$ & .26 & .61 \\
\hline $\begin{array}{l}\text { Self-Efficacy: } \\
\text { Exercise }\end{array}$ & 40 & $\begin{array}{c}46.65 \pm 20.3 \\
4\end{array}$ & 92 & $37.92 \pm 18.87$ & 3.90 & .05 \\
\hline
\end{tabular}

As shown in Table 10, no significant differences between the intervention and the control groups were found at baseline in terms of nutrition knowledge, eating and 
exercise social support that students received from family and friends, eating habits and exercise self-efficacy, and fruits and vegetables intake.

Table 11.

Descriptive Table by Group at Baseline "Distal Outcomes"

\begin{tabular}{|c|c|c|c|c|c|c|}
\hline & \multicolumn{2}{|c|}{ Intervention Group } & \multicolumn{2}{|c|}{ Control Group } & \multirow{2}{*}{$\mathbf{F}$} & \multirow{2}{*}{ Sig. } \\
\hline & $\mathbf{N}$ & Mean \pm SD & $\mathbf{N}$ & Mean \pm SD & & \\
\hline Fruits and Vegetables & 42 & $2.99 \pm 3.44$ & 41 & $2.45 \pm 2.47$ & 0.68 & .41 \\
\hline Only Fruits & 42 & $2.1 \pm 2.5$ & 41 & $1.48 \pm 1.89$ & 1.44 & .23 \\
\hline Only Vegetables & 42 & $0.92 \pm 1.16$ & 42 & $0.95 \pm 0.89$ & 0.02 & .89 \\
\hline Physical Activity & 46 & $9.98 \pm 5.01$ & 44 & $10.09 \pm 4.71$ & 0.01 & .91 \\
\hline Height & 55 & $157.02 \pm 5.88$ & 48 & $156.91 \pm 6.86$ & .01 & .93 \\
\hline Body Weight & 55 & $58.49 \pm 14.14$ & 48 & $60.74 \pm 15.38$ & .59 & .45 \\
\hline BMI & 55 & $23.63 \pm 5.23$ & 48 & $24.60 \pm 5.50$ & .83 & .37 \\
\hline Waist Circumference & 55 & $71.90 \pm 10.42$ & 48 & $70.44 \pm 10.70$ & .49 & .49 \\
\hline
\end{tabular}

Table 11 represents the differences between the two groups at baseline in terms of the main study outcomes. It shows that there is no differences between the groups in fruits and vegetable consumption, physical activity level, and anthropometric measurements.

The current study also looked at the daily usage of phone and social media among college students at baseline (Table 12). About 20\% used their phone more than 6 hours per day. Among the platforms, Snapchat seems to be the most frequently used by college students ( 70\%), followed by Whatsapp (61.2\%) and Instagram (55.3\%). A high 
percentage (26.2\%) reported that they use social networks all day and about (50\%) check their social network accounts in the evening.

Table 12:

Social Networks Usage

\begin{tabular}{lccc}
\hline & Characteristics & N & \% \\
\hline Phone Usage per Day & & & \\
& $<1$ hour & 1 & 1 \\
& $1-2$ hours & 5 & 4.9 \\
& $3-4$ hours & 18 & 17.5 \\
& $4-6$ hours & 25 & 24.3 \\
& $>$ 6 hours & 20 & 19.4 \\
& All day & 33 & 32 \\
Social Network Used & & \\
& & & \\
& Instagram & 57 & 55.3 \\
& Snapchat & 72 & 69.9 \\
& Twitter & 37 & 35.9 \\
& Facebook & 0 & 0 \\
& Pintrest & 3 & 2.9 \\
& Whatsapp & 63 & 61.2 \\
& Path & 8 & 7.8 \\
& Swarm & 1 & 1
\end{tabular}

Number of hours of social networks per Day

$\begin{array}{ccc}\text { Not at all } & 0 & 0 \\ \text { Not every day } & 2 & 1.9 \\ <\text { 1 hour } & 3 & 2.9 \\ \text { 1-2 hours } & 21 & 20.4 \\ \text { 3-4 hours } & 20 & 19.4 \\ \text { 4-6 hours } & 18 & 17.5 \\ >\text { 6 hours } & 11 & 10.7 \\ \text { All day } & 27 & 26.2 \\ \text { Do not have access to check daily } & 0 & \end{array}$

How often you Create "post" on Social Networks

$\begin{array}{ccc}\text { Several times a day } & 16 & 15.5 \\ \text { Once a day } & 12 & 11.7 \\ \text { A few times a week } & 25 & 24.3 \\ \text { Once a week } & 12 & 11.7 \\ \text { A few times a month } & 15 & 14.6 \\ \text { Once a month } & 9 & 8.7 \\ \text { A few times a year } & 7 & 6.8 \\ \text { Never } & 6 & 5.8\end{array}$

Most Likely Use Social Networks

\begin{tabular}{cll} 
Right when you wake up & 24 & 23.3 \\
Morning & 24 & 23.3 \\
Afternoon & 26 & 25.2 \\
Evening & 51 & 49.5 \\
\hline
\end{tabular}




\begin{tabular}{lll}
\hline Right before bed & 27 & 26.2 \\
All day long & 22 & 21.4 \\
& & \\
\hline
\end{tabular}

$\mathrm{N}=103$

\section{Retention:}

Seventy-two (31\%) out of a hundred three of randomized students completed the post intervention questionnaire. In examining demographic factors as predictors for noncompletion of the study at 6 weeks, there was no significant effect of any demographic factors including age, marital status, number of children, university level, and GPA (Table 13).

Table 13:

Completers VS Non-Completers in Demographics

\begin{tabular}{|c|c|c|c|c|c|c|c|}
\hline & & \multicolumn{2}{|c|}{ Completers } & \multicolumn{2}{|c|}{$\begin{array}{c}\text { Non- } \\
\text { Completers }\end{array}$} & \multicolumn{2}{|c|}{ Chi-Square } \\
\hline \multirow{3}{*}{ Age } & & $\mathrm{N}$ & $\%$ & $\mathrm{~N}$ & $\%$ & Value & $\begin{array}{c}\text { Asymp. } \\
\text { Sig. (2- } \\
\text { sided) }\end{array}$ \\
\hline & $18-24$ & 69 & 95.8 & 31 & 100 & & \\
\hline & $25-34$ & 3 & 4.2 & 0 & 0 & .25 & .55 \\
\hline \multirow{3}{*}{$\begin{array}{c}\text { Marital } \\
\text { Status }\end{array}$} & Single & 67 & 93.1 & 28 & 90.3 & \multirow{3}{*}{2.35} & \multirow{3}{*}{.31} \\
\hline & Married & 5 & 6.9 & 2 & 6.5 & & \\
\hline & Separated & 0 & 0 & 1 & 3.2 & & \\
\hline \multirow[t]{2}{*}{ \#of children } & $\begin{array}{l}\text { No } \\
\text { children }\end{array}$ & 70 & 97.2 & 30 & 96.8 & \multirow{2}{*}{.02} & \multirow{2}{*}{1.0} \\
\hline & 1 & 2 & 2.8 & 1 & 3.2 & & \\
\hline \multirow{8}{*}{$\begin{array}{c}\text { University } \\
\text { Level }\end{array}$} & Level 1 & 5 & 6.9 & 1 & 3.2 & \multirow{8}{*}{5.79} & \multirow{8}{*}{.57} \\
\hline & Level 2 & 12 & 16.7 & 6 & 19.4 & & \\
\hline & Level 3 & 4 & 5.6 & 3 & 9.7 & & \\
\hline & Level 4 & 26 & 36.1 & 16 & 51.6 & & \\
\hline & Level 5 & 4 & 5.6 & 0 & 0 & & \\
\hline & Level 6 & 6 & 8.3 & 2 & 6.5 & & \\
\hline & Level 7 & 5 & 6.9 & 1 & 3.2 & & \\
\hline & Level 8 & 10 & 13.9 & 2 & 6.5 & & \\
\hline \multirow[t]{3}{*}{ GPA } & 5 & 2 & 2.8 & 0 & 0 & \multirow{3}{*}{8.26} & \multirow{3}{*}{.22} \\
\hline & $4.75-4.99$ & 6 & 8.3 & 7 & 24.1 & & \\
\hline & $4.5-4.74$ & 15 & 20.8 & 2 & 6.9 & & \\
\hline
\end{tabular}




\begin{tabular}{ccccc}
\hline $4.0-4.49$ & 17 & 23.6 & 5 & 17.2 \\
$3.5-3.99$ & 23 & 31.9 & 11 & 37.9 \\
$3.0-3.49$ & 8 & 11.1 & 3 & 10.3 \\
Lower & 1 & 1.4 & 1 & 3.4 \\
\hline
\end{tabular}

In addition, there were no significant differences found between completers and non-completers for SCT mediators. However, in examining changes in the mediators the non-completers disproportionately scored less in nutrition knowledge, had lower family and friend social support for eating, lower family but not friend social support and exercise, and lower self-efficacy with eating habits but not with exercise scores (Table 14). Moreover, when examining distal outcomes, no significant differences between the completers and non-completers were found. However, the non-completers were less likely to consume fruits and vegetables and had lower body weight. Yet, non-completers had a higher physical activity score (Table 15).

Table 14:

Completers VS Non-Completers in Changes in Mediators based on SCT

\begin{tabular}{|c|c|c|c|c|c|c|}
\hline & \multicolumn{2}{|c|}{ Completers } & \multicolumn{2}{|c|}{ Non-Completers } & \multirow{2}{*}{$\mathbf{F}$} & \multirow{2}{*}{ Sig. } \\
\hline & $\mathbf{N}$ & Mean \pm SD & $\mathbf{N}$ & Mean \pm SD & & \\
\hline $\begin{array}{l}\text { Modified Nutrition } \\
\text { Knowledge }\end{array}$ & 59 & $17.08 \pm 5.65$ & 24 & $14.92 \pm 6.86$ & 2.21 & .14 \\
\hline $\begin{array}{c}\text { Social Support \& } \\
\text { Eating: Family }\end{array}$ & 31 & $29.32 \pm 7.29$ & 16 & $25.69 \pm 6.83$ & 2.74 & .11 \\
\hline $\begin{array}{c}\text { Social Support \& } \\
\text { Eating: Friends }\end{array}$ & 33 & $26.45 \pm 6.88$ & 16 & $24.19 \pm 4.96$ & 1.38 & .25 \\
\hline $\begin{array}{l}\text { Social Support \& } \\
\text { Exercise: Family }\end{array}$ & 32 & $\begin{array}{c}39.16 \pm 20.4 \\
6\end{array}$ & 12 & $34.67 \pm 11.48$ & .51 & .48 \\
\hline $\begin{array}{l}\text { Self-Efficacy: } \\
\text { Eating Habits }\end{array}$ & 31 & $\begin{array}{c}72.71 \pm 19.1 \\
2\end{array}$ & 10 & $69.90 \pm 24.22$ & .14 & .71 \\
\hline $\begin{array}{l}\text { Self-Efficacy: } \\
\text { Exercise }\end{array}$ & 56 & $\begin{array}{c}41.11 \pm 18.1 \\
8\end{array}$ & 23 & $45.35 \pm 24.04$ & .73 & .40 \\
\hline
\end{tabular}


Table 15:

Completers VS Non-Completers in Changes in Outcomes

\begin{tabular}{|c|c|c|c|c|c|c|}
\hline & \multicolumn{2}{|c|}{ Completers } & \multicolumn{2}{|c|}{ Non-Completers } & \multirow{2}{*}{$\mathbf{F}$} & \multirow{2}{*}{ Sig. } \\
\hline & $\mathbf{N}$ & Mean \pm SD & $\mathbf{N}$ & Mean \pm SD & & \\
\hline Fruits and Vegetables & 57 & $2.89 \pm 3.17$ & 26 & $2.37 \pm 2.60$ & 0.54 & .47 \\
\hline Only Fruits & 57 & $1.82 \pm 2.36$ & 26 & $1.69 \pm 1.94$ & .07 & .79 \\
\hline Only Vegetables & 58 & $1.05 \pm 1.10$ & 26 & $0.68 \pm 0.79$ & 2.33 & .13 \\
\hline Physical Activity & 72 & $34.49 \pm 21.10$ & 31 & $36.87 \pm 63$ & .22 & .64 \\
\hline Body Weight & 72 & $60.59 \pm 15.20$ & 31 & $\begin{array}{c}57.09 \pm 13.7 \\
2\end{array}$ & 1.21 & .27 \\
\hline
\end{tabular}

\section{Research Specific Aims}

\section{Aim 1: Examine the role of SM on college students eating behaviors.}

In order to examine the role of social media on students' eating behaviors, the investigator created 16 questions. Based on modification indices from the reliability measures, three non-correlated items were excluded from the analysis. The reliability of the resulting 15 items was $\alpha=0.6$. Of the full sample of college females, $36 \%$ of the participants reported that they liked food advertisements on social media. More than $45 \%$ spent their money on food that they watched on SM. About $40 \%$ indicated they were interested in viewing unhealthy foods more than healthy foods. More than $47 \%$ reported that watching food on social media increases their hunger. Interestingly, $41.1 \%$ reported that they only follow those who are posting healthy foods. Moreover, 35.2\% reported that they only watched food posts on social media. Table 16 characterizes the students' social media behaviors. 
Table 16.

Students' Social Media Behaviors

\begin{tabular}{|c|c|c|c|c|c|c|c|c|c|c|}
\hline & \multicolumn{2}{|c|}{$\begin{array}{l}\text { Strongly } \\
\text { agree }\end{array}$} & \multicolumn{2}{|c|}{ Agree } & \multicolumn{2}{|c|}{$\begin{array}{c}\text { Does not } \\
\text { apply }\end{array}$} & \multicolumn{2}{|c|}{ Disagree } & \multicolumn{2}{|c|}{$\begin{array}{l}\text { Strongly } \\
\text { disagree }\end{array}$} \\
\hline & $\mathbf{N}$ & $\%$ & $\mathbf{N}$ & $\%$ & $\mathbf{N}$ & $\%$ & $\mathbf{N}$ & $\%$ & $\mathbf{N}$ & $\%$ \\
\hline $\begin{array}{l}\text { My parents agree about any } \\
\text { food I purchase after any food } \\
\text { advertisement }\end{array}$ & 4 & 4.4 & 17 & 18.9 & 25 & 27.8 & 32 & 35.6 & 12 & 13.3 \\
\hline $\begin{array}{l}\text { I am not interested in } \\
\text { watching unhealthy food on } \\
\text { social media }\end{array}$ & 17 & 18.9 & 30 & 33.3 & 14 & 15.6 & 22 & 24.4 & 7 & 7.8 \\
\hline $\begin{array}{l}\text { I am interested in watching } \\
\text { unhealthy food more than } \\
\text { healthy food }\end{array}$ & 21 & 23.3 & 21 & 23.2 & 10 & 11.1 & 35 & 38.9 & 3 & 3.3 \\
\hline $\begin{array}{l}\text { Watching the celebrities on } \\
\text { social media pushes me to } \\
\text { reduce my body weight }\end{array}$ & 23 & 25.6 & 36 & 40.0 & 18 & 20 & 12 & 13.3 & 1 & 1.1 \\
\hline \multirow[t]{3}{*}{$\begin{array}{l}\text { Watching food on social } \\
\text { media increases my hunger }\end{array}$} & 25 & 27.8 & 43 & 47.8 & 8 & 8.9 & 5 & 5.6 & 9 & 10 \\
\hline & \multicolumn{2}{|c|}{ Rarely } & \multicolumn{2}{|c|}{ Sometimes } & \multicolumn{2}{|c|}{ Often } & \multicolumn{2}{|c|}{$\begin{array}{l}\text { Most of } \\
\text { the time }\end{array}$} & \multicolumn{2}{|c|}{ Always } \\
\hline & $\mathbf{N}$ & $\%$ & $\mathbf{N}$ & $\%$ & $\mathbf{N}$ & $\%$ & $\mathbf{N}$ & $\%$ & $\mathbf{N}$ & $\%$ \\
\hline $\begin{array}{l}\text { I immediately go purchasing } \\
\text { food after food advertisement }\end{array}$ & 25 & 27.8 & 27 & 30.0 & 9 & 10.0 & 1 & 1.1 & 28 & 31.1 \\
\hline $\begin{array}{l}\text { I feel that I really want to } \\
\text { purchase the food that I just } \\
\text { watched on social media }\end{array}$ & 25 & 30.9 & 19 & 23.5 & 14 & 17.3 & 9 & 11.1 & 14 & 17.3 \\
\hline I ignore any unhealthy post & 23 & 26.4 & 6 & 6.9 & 10 & 11.5 & 24 & 27.6 & 24 & 27.6 \\
\hline
\end{tabular}

A correlation matrix was utilized to examine the relationships between social media participation and target health behaviors and BMI at baseline. Among the social media platform, Instagram was the only one correlated to BMI. However, none of the social media platforms were correlated to fruits and vegetables intake or physical activity at baseline. Table 17 presents all of the correlations. 
Table 17:

Correlation Matrix, Means, and Standard Deviations of Major Study Variable

\begin{tabular}{|c|c|c|c|c|c|c|c|c|c|c|c|c|c|c|}
\hline Variables & BMI & Instagram & Snapchat & Twitter & Facebook & Pintrest & Whatsapp & Path & Swarm & Other & $\mathbf{A S M}$ & $\mathbf{F} \& V$ & Fruit & Veg. \\
\hline BMI & 1 & & & & & & & & & & & & & \\
\hline Instagram & $.309 * *$ & 1 & & & & & & & & & & & & \\
\hline Snapchat & -.077 & -.010 & 1 & & & & & & & & & & & \\
\hline Twitter & -.155 & -.110 & .039 & 1 & & & & & & & & & & \\
\hline Facebook & $\mathrm{b}$ & $\mathrm{b}$ & $\mathrm{b}$ & $\mathrm{b}$ & 1 & & & & & & & & & \\
\hline Pintrest & .055 & .155 & -.015 & -.011 & $\mathrm{~b}$ & 1 & & & & & & & & \\
\hline Whatsapp & .115 & .032 & $.289 * *$ & .090 & $\mathrm{~b}$ & -.102 & 1 & & & & & & & \\
\hline Path & -.007 & -.108 & .028 & .007 & $\mathrm{~b}$ & -.051 & .079 & 1 & & & & & & \\
\hline Swarm & -.034 & .088 & .064 & .32 & $\mathrm{~b}$ & -.017 & .078 & .029 & 1 & & & & & \\
\hline Others & $.207 *$ & -.105 & -.077 & .094 & $\mathrm{~b}$ & .138 & $-.216 * *$ & .149 & -.033 & 1 & & & & \\
\hline SM & .034 & .128 & -.011 & .212 & $\mathrm{~b}$ & .118 & .139 & $\begin{array}{c}- \\
.164\end{array}$ & -.001 & .010 & 1 & & & \\
\hline $\mathbf{F} \& V$ & .174 & .101 & -.147 & -.022 & $\mathrm{~b}$ & .069 & .061 & $\begin{array}{c}- \\
.012\end{array}$ & -.026 & -.001 & -.038 & 1 & & \\
\hline Veg. & .115 & .117 & -.142 & -.065 & $\mathrm{~b}$ & -.036 & 1 & .032 & .075 & .005 & -.082 & -.083 & $.821 * *$ & 1 \\
\hline \multicolumn{15}{|c|}{ **. Correlation is significant at the 0.01 level (2-tailed). } \\
\hline \multicolumn{15}{|c|}{ *. Correlation is significant at the 0.05 level (2-tailed). } \\
\hline b. Cannot be cc & nputed bec & use at least one $\mathrm{o}$ & f the variables & constant & & & & & & & & & & \\
\hline
\end{tabular}




\section{Aim 2: Examine the implementation feasibility and promise of a SM+Tracking intervention to change college students obesogenic health behaviors (fruit and vegetable intake \& PA).}

\section{Feasibility Studies and Research Hypotheses}

\section{Feasibility 1:}

Feasibility of the research design was demonstrated by baseline recruitment of 100 students, assuming $60 \%$ retention (with complete data) at post-test and $50 \%$ retention (with complete data) at follow-up.

A total of 135 students expressed interest in participating in the study. However, only 103 completed the baseline assessment. Of the 103 participants, 55 were randomized to the intervention group (6 weeks) and 48 to the control group. Retention at post intervention supported the Feasibility 1, with 71 of 103 ( 60\%) participants completing the post intervention assessment. However, the second part of the feasibility study was not supported, with only 28 of $103(27 \%)$ participants completing the 4-week follow-up (post intervention) assessment (Figure 2).

\section{Feasibility 2:}

Feasibility of the intervention will be demonstrated by the number of likes, comments, and share in Instagram and strong satisfaction with intervention goals, content and format.

\section{1- Engagement:}

Level of engagement was examined for the Instagram group by quantifying the number of times participants "liked" a study-related post. 


\section{Instagram}

\section{Participant Use:}

Of the 55 participants in the intervention group, 53 subjects participated by liking, or commenting on study-related Instagram posts resulting in 26 comments to the Instagram group. Only 5 students $(9.1 \%)$ shared study-related Instagram posts while, 8 students $(14.5 \%)$ participated in the study challenges. Intervention activity (likes, comments, shares and challenges) participation was high at the beginning and declined over time $($ Range $=13-35$, mean $=24)($ Figure 3$)$.

Figure 3.

The Participants' Activity during the Study Period

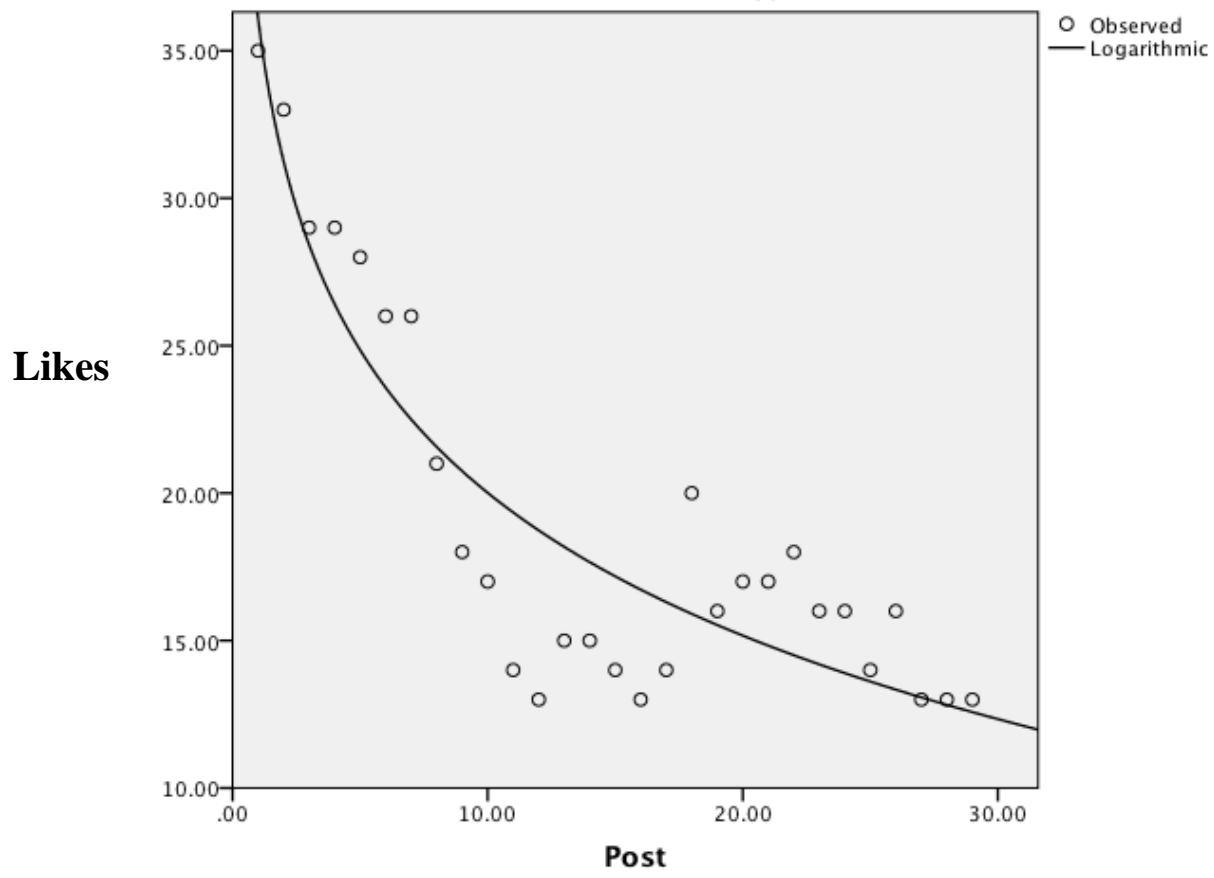




\section{2- Acceptability/Satisfaction:}

Table 18.

Satisfaction Items

\begin{tabular}{lllllllll}
\hline \multirow{2}{*}{ Item } & Disagree & Neutral & $\begin{array}{c}\text { Somewhat } \\
\text { agree }\end{array}$ & \multicolumn{2}{c}{ Agree } \\
& & & & & & & \\
\hline & N & $\%$ & N & $\%$ & N & $\%$ & N & $\%$
\end{tabular}

Did the daily food log help you

think about your portions?

$\begin{array}{llll}27 & 65.9 & 14 & 34.1\end{array}$

I will continue using the self-

$\begin{array}{lllllllll}\text { tracking app or any similar } & 24 & 58.5 & 4 & 9.8 & 1 & 2.4 & 12 & 29.3\end{array}$

app

Instagram pictures/videos

motivated me to consume

fruits and vegetables

Instagram topics motivated me

to consume fruits and

vegetables

In general, Instagram posts

were interested and helpful

I will participate in a similar

study in future

I will encourage my friends

and relatives to participate in

similar research

I will continue applying what

I've learned

In general, the study was easy

Using multiple apps in the study were annoying

$\begin{array}{llllll}13 & 31.7 & 26 & 63.4 & 2 & 4.9\end{array}$


A 10-item acceptability/satisfaction questionnaire was developed by the investigator for the purpose of the study. This questionnaire was provided to the intervention group (41 students) post intervention. Among Instagram participants who completed satisfaction measures $(n=41), 100 \%$ found the Instagram topics interesting and motivating, $100 \%$ reported the intervention was interesting and helpful, $95 \%$ found that the Instagram pictures and videos motivated them to increase their consumption of fruits and vegetables, and $80 \%$ would encourage their friends and relatives to participate in similar intervention.

Related to the mDiet self-tracking app, only $34 \%$ thought that daily food log helped them think about portion sizes. Only $29 \%$ reported they would continue using the self-tracking app. About 63\% reported that using multiple apps was annoying, while only $\sim 4 \%$ found it not annoying. Additional items are presented in Table 18.

For hypotheses 1-4, repeated measures ANOVA was utilized. This analysis technique is used to assess in one dependent measured several times. The changes in the mediators and outcome variables between pre and post intervention were examined and presented in Table 19 and Table 20, respectively. Moreover, the changes in outcome variables between post and follow-up were tested (Table 21).

\section{Hypothesis 1:}

There will be a difference between the control and the intervention group in terms of change mediators based on SCT. The intervention group will report higher nutrition knowledge, family and friend social support for eating and exercise, self-efficacy for eating and self-efficacy for exercise than the control group post intervention. 


\section{Mediators}

\section{Nutrition Knowledge:}

The intervention group demonstrated significantly higher knowledge than the control group post intervention, Wilks' Lambda $=.6, \mathrm{~F}(1,45)=.30 .1, \mathrm{p}<.05$ (Table 19).

\section{Family and Friends Social Support and}

\section{Eating Habits:}

The intervention group demonstrated significantly higher family support with eating habits post intervention, Wilks' Lambda $=.9, \mathrm{~F}(1,30)=4.8, \mathrm{p}<.05$ (Table 17). However, the change with friends social support and exercise was not statistically significant between intervention and control groups, Wilks' Lambda= .9, $\mathrm{F}(1,17)=, 12$, p> .05 (Table 19).

Exercise:

The intervention group demonstrated significantly higher family support with exercise post intervention, Wilks' Lambda $=.9, \mathrm{~F}(1,30)=4.8, \mathrm{p}<.05$ (Table 19). However, the change with friends social support and exercise was not statistically significant between intervention and control groups, Wilks' Lambda= .9, $\mathrm{F}(1,17)=, 12$, p> .05 (Table 19).

\section{Eating Habits and Exercise Self-Efficacy}

The change in eating behaviors self-efficacy scores from pre-test to post-test was significantly higher in the intervention than the control group, Wilks' Lambda= .9, $\mathrm{F}(1,53)=4.9, \mathrm{p}<.05$ (Table 19). Additionally, the intervention group demonstrated 
significantly higher exercise self-efficacy than the control group post intervention, Wilks' Lambda $=.8, \mathrm{~F}(1,54)=11.8, \mathrm{p}<.05$ (Table 19).

Hypothesis 2: There will be a difference between the control and the intervention group in fruits and vegetables consumption. The intervention group will report higher fruits and vegetables intake than the control group post intervention and increase or stay the same at follow up.

Descriptive statistics for changes in fruits and vegetables intake for groups pre, post, and follow-up are presented in Table 20 and Table 21, respectively. Table 20 shows that the change in fruits and vegetables intake scores from pre-test to post-test was not significantly different between intervention and control groups, Wilks' Lambda= .9, $\mathrm{F}(1,55)=1.2, \mathrm{p}>.05$. There was however, a small interaction effect found between the two groups where the intervention increased fruit and vegetable intake while the control group decreased their fruit and vegetable intake as a result of the intervention $(\mathrm{d}=.35)$. Furthermore, when testing the changes in fruits intake separately for groups pre, post there is a significant difference between intervention and control groups, Wilks' Lambda $=.67, F(1,55)=62.8, \mathrm{p}<.05$. Table 21 shows that the change from post-test to follow-up was not significantly different between intervention and control groups, Wilks' Lambda $=.96, F(1,55)=1.0, \mathrm{p}>.05$.

Hypothesis 3: There will be a difference between the control and the intervention group in terms of physical activity. The intervention group will report physical activity level higher than the control group. 
Descriptive statistics for the physical activity for the two groups pre and post test are presented in Table 20 and post-test to follow-up in Table 21 . The change in physical activity scores from pre-test to post-test was not significantly different between intervention and control groups, Wilks' Lambda $=.96, F(1,70)=2.25, \mathrm{p}>.05$ (Table 20). The intervention group experienced a moderate within group effect $(\mathrm{d}=.03)$, however no between group effect was found. A similar result was found in the post and follow-up test, no significant difference between the groups was found Wilks' Lambda $=.99$, $\mathrm{F}(1,26)=.38, \mathrm{p}>.05$, yet there was a significant difference within the groups. The intervention group experienced increased in physical activity in the post and follow-up test $(\mathrm{d}=.02)($ Table 21$)$.

Hypothesis 4: There will be a difference between the control and the intervention group in terms of body weight. The intervention group will experience reduction in body weight, while the control group will gain weight.

The main aim of the current study is preventing weight gain among female college students. Descriptive statistics for changes in BW for the two groups pre and post test are presenting in Table 20 and post-test to follow-up in Table 21. At 6 weeks, weight changes were $-.97 \mathrm{~kg}$ for Instagram group and $+.55 \mathrm{~kg}$ for control group. Theses changes were not statistically significant between the groups, Wilks' Lambda $=.99, F(1,70)=.39$, p> .05 (Table 20). At 4 weeks follow up, weight changes were $-.71 \mathrm{~kg}$ for Instagram group and $+.44 \mathrm{~kg}$ for control group. Theses changes were not statistically significant between the groups, Wilks' Lambda $=.99, \mathrm{~F}(1,26)=.26, \mathrm{p}>.05$ (Table 21). 
Table 19.

Repeated Measure ANOVA and Effect Sizes for Study Mediators

\begin{tabular}{|c|c|c|c|c|c|c|c|c|c|c|}
\hline & \multicolumn{3}{|c|}{ Intervention } & \multicolumn{3}{|c|}{ Control } & \multicolumn{4}{|c|}{ Comparison } \\
\hline & $\mathbf{N}$ & Mean \pm SD & $\begin{array}{c}\text { Within } \\
\text { Group Effect } \\
\text { (Cohen's } d \text { ) }\end{array}$ & Mean \pm SD & $\mathbf{N}$ & $\begin{array}{c}\text { Within Group } \\
\text { Effect } \\
\text { (Cohen's } d \text { ) }\end{array}$ & $\begin{array}{c}\text { Wilks' } \\
\text { Lambda }\end{array}$ & $\mathbf{F}$ & P-value & $\begin{array}{c}\text { Between } \\
\text { Group Effect } \\
\text { (Hedges } d)\end{array}$ \\
\hline \multicolumn{11}{|c|}{ Nutrition Knowledge } \\
\hline Pre & 29 & $16.34 \pm 6.61$ & 1.18 & $17.00 \pm 5.20$ & 18 & .60 & .599 & 30.10 & $<0.001 *$ & .61 \\
\hline Post & 29 & $23.03 \pm 4.57$ & & $19.94 \pm 4.65$ & 18 & & & & & \\
\hline \multicolumn{11}{|c|}{ Social Support for Eating - Family } \\
\hline Pre & 15 & $24.53 \pm 7.27$ & 0.34 & $26.65 \pm 6.10$ & 17 & .18 & .863 & 4.75 & $.037 *$ & .17 \\
\hline Post & & $26.60 \pm 4.60$ & & $27.60 \pm 4.60$ & & & & & & \\
\hline \multicolumn{11}{|c|}{ Social Support for Eating - Friends } \\
\hline Pre & 11 & $26.00 \pm 7.20$ & .23 & $30.00 \pm 4.08$ & 4 & -1.06 & .992 & .102 & .755 & .25 \\
\hline Post & & $27.82 \pm 8.48$ & & $26.00 \pm 3.46$ & & & & & & \\
\hline \multicolumn{11}{|c|}{ Social Support for Physical Activity - Family } \\
\hline Pre & 24 & $38.92 \pm 20.65$ & .31 & $39.88 \pm 21.26$ & 8 & 0 & 0.82 & 6.82 & $.014 *$ & .29 \\
\hline Post & 24 & $44.96 \pm 17.97$ & & $39.88 \pm 20.63$ & 8 & & & & & \\
\hline \multicolumn{11}{|c|}{ Social Support for Physical Activity - Friends } \\
\hline Pre & 14 & $37.21 \pm 10.33$ & .29 & $28.40 \pm 4.72$ & 5 & 0 & .881 & 2.29 & .149 & .31 \\
\hline Post & 5 & $40.14 \pm 9.55$ & & $28.40 \pm 4.72$ & & & & & & \\
\hline \multicolumn{11}{|c|}{ Self-Efficacy for Eating Habits } \\
\hline Pre & 15 & $69.93 \pm 20.27$ & 1.52 & $75.31 \pm 18.25$ & 16 & .03 & .854 & 4.94 & $.034 *$ & .26 \\
\hline Post & & $75.60 \pm 15.98$ & & $75.50 \pm 18.27$ & & & & & & \\
\hline \multicolumn{11}{|c|}{ Self-Efficacy for Physical Activity } \\
\hline Pre & 28 & $44.54 \pm 19.02$ & .39 & $37.68 \pm 16.95$ & 28 & .03 & .821 & 11.80 & $.001 *$ & .42 \\
\hline Post & & $51.64 \pm 17.63$ & & $37.21 \pm 15.38$ & & & & & & \\
\hline
\end{tabular}


Table 20.

Repeated Measure ANOVA and Effect Sizes for Study Outcomes (Pre - Post)

\begin{tabular}{|c|c|c|c|c|c|c|c|c|c|c|}
\hline & \multicolumn{3}{|c|}{ Intervention } & \multicolumn{3}{|c|}{ Control } & \multicolumn{4}{|c|}{ Comparison } \\
\hline & $\mathbf{N}$ & Mean \pm SD & $\begin{array}{c}\text { Within } \\
\text { Group Effect } \\
\text { (Cohen's } d \text { ) }\end{array}$ & $\mathbf{N}$ & Mean \pm SD & $\begin{array}{l}\text { Within Group } \\
\text { Effect } \\
\text { (Cohen's } d \text { ) }\end{array}$ & $\begin{array}{l}\text { Wilks' } \\
\text { Lambda }\end{array}$ & $\mathbf{F}$ & P-value & $\begin{array}{c}\text { Between } \\
\text { Group Effect } \\
\text { (Hedges } d \text { ) }\end{array}$ \\
\hline $\begin{array}{l}\text { Fruit } \\
\text { Pre } \\
\text { Post }\end{array}$ & $\begin{array}{l}\text { take } \\
29\end{array}$ & $\begin{array}{l}2.24 \pm 2.79 \\
2.64 \pm 2.82\end{array}$ & .14 & 28 & $\begin{array}{l}1.39 \pm 1.76 \\
1.43 \pm 1.75\end{array}$ & .02 & .67 & 26.88 & 0.10 & .15 \\
\hline \multicolumn{11}{|c|}{ Vegetable Intake } \\
\hline $\begin{array}{l}\text { Pre } \\
\text { Post }\end{array}$ & 29 & $\begin{array}{l}1.09 \pm 1.29 \\
1.36 \pm 1.20\end{array}$ & .21 & 29 & $\begin{array}{l}1.02 \pm 0.91 \\
0.56 \pm 0.45\end{array}$ & -.64 & .98 & 1.23 & .09 & .65 \\
\hline \multicolumn{11}{|c|}{ Fruit and Vegetable Intake } \\
\hline $\begin{array}{l}\text { Pre } \\
\text { Post }\end{array}$ & 29 & $\begin{array}{l}3.33 \pm 3.84 \\
4.00 \pm 3.78\end{array}$ & .18 & 28 & $\begin{array}{l}2.43 \pm 2.26 \\
2.00 \pm 1.85\end{array}$ & -.21 & .98 & 1.24 & .271 & .35 \\
\hline \multicolumn{11}{|c|}{ Physical activity } \\
\hline $\begin{array}{l}\text { Pre } \\
\text { Post }\end{array}$ & 41 & $\begin{array}{l}35.3 \pm 21.7 \\
41.8 \pm 21.0\end{array}$ & 0.30 & 30 & $\begin{array}{l}33.5 \pm 20.9 \\
30.0 \pm 19.5\end{array}$ & .17 & .9 & 2.3 & .50 & .03 \\
\hline Body & eigh & & & & & & & & & \\
\hline $\begin{array}{l}\text { Pre } \\
\text { Post }\end{array}$ & 41 & $\begin{array}{l}58.28 \pm 15.67 \\
57.31 \pm 15.36\end{array}$ & -.06 & 31 & $\begin{array}{l}63.64 \pm 14.22 \\
64.19 \pm 14.34\end{array}$ & .04 & .99 & .39 & .54 & .10 \\
\hline
\end{tabular}


Table 21.

Repeated Measure ANOVA and Effect Sizes for Study Outcomes (Post - Follow-up)

\begin{tabular}{|c|c|c|c|c|c|c|c|c|c|c|}
\hline & \multicolumn{3}{|c|}{ Intervention } & \multicolumn{3}{|c|}{ Control } & \multicolumn{4}{|c|}{ Comparison } \\
\hline & $\mathbf{N}$ & Mean \pm SD & $\begin{array}{c}\text { Within } \\
\text { Group Effect } \\
(\text { Cohen's } d \text { ) }\end{array}$ & $\mathbf{N}$ & Mean \pm SD & $\begin{array}{c}\text { Within } \\
\text { Group Effect } \\
\text { (Cohen's } d \text { ) }\end{array}$ & $\begin{array}{l}\text { Wilks' } \\
\text { Lambda }\end{array}$ & $\mathbf{F}$ & P-value & $\begin{array}{c}\text { Between } \\
\text { Group Effect } \\
(\text { Hedges } d)\end{array}$ \\
\hline \multicolumn{11}{|c|}{ Fruit Intake } \\
\hline $\begin{array}{l}\text { Post } \\
\text { FU }\end{array}$ & 12 & $\begin{array}{l}2.22 \pm 1.76 \\
2.39 \pm 2.15\end{array}$ & .09 & 12 & $\begin{array}{l}1.05 \pm 1.15 \\
1.28 \pm 1.60\end{array}$ & .07 & .98 & .44 & .52 & .27 \\
\hline \multicolumn{11}{|c|}{ Vegetable Intake } \\
\hline $\begin{array}{l}\text { Post } \\
\text { FU }\end{array}$ & 14 & $\begin{array}{l}0.84 \pm 0.95 \\
0.81 \pm 0.82\end{array}$ & .03 & 13 & $\begin{array}{l}0.56 \pm 0.38 \\
0.94 \pm 0.82\end{array}$ & .59 & .90 & 2.69 & .11 & .56 \\
\hline \multicolumn{11}{|c|}{ Fruit and Vegetable Intake } \\
\hline $\begin{array}{l}\text { Post } \\
\text { FU }\end{array}$ & 12 & $\begin{array}{l}3.11 \pm 2.66 \\
3.18 \pm 2.56\end{array}$ & .03 & 12 & $\begin{array}{l}1.63 \pm 1.31 \\
2.23 \pm 1.96\end{array}$ & .36 & .96 & 1.00 & .33 & .25 \\
\hline \multicolumn{11}{|c|}{ Physical activity } \\
\hline $\begin{array}{l}\text { Post } \\
\text { FU }\end{array}$ & 13 & $\begin{array}{l}43.77 \pm 24.04 \\
40.69 \pm 35.51\end{array}$ & .10 & 13 & $\begin{array}{l}31.00 \pm 24.34 \\
27.38 \pm 18.39\end{array}$ & .17 & .99 & .38 & .55 & .02 \\
\hline \multicolumn{11}{|c|}{ Body Weight } \\
\hline $\begin{array}{l}\text { Post } \\
\text { FU }\end{array}$ & 15 & $\begin{array}{l}56.14 \pm 12.96 \\
55.43 \pm 12.53\end{array}$ & 1.07 & 13 & $\begin{array}{l}61.18 \pm 14.51 \\
61.62 \pm 14.76\end{array}$ & .03 & .99 & .26 & .62 & .08 \\
\hline
\end{tabular}




\section{Summary}

The final section of this chapter will provide a summary of the results of the analysis of the hypotheses and research aims for this study. A p-value $<0.05$ was used to make decisions about accepting and rejecting the null hypotheses. Table 22 summarizes theses analysis and related decisions as well as the significance levels for the hypotheses tested.

Table 22

Summary of Findings for Hypotheses

\begin{tabular}{|c|c|c|}
\hline \multicolumn{3}{|c|}{ Promise Summary } \\
\hline Hypothesis 1: & Findings & Decision \\
\hline \multicolumn{3}{|c|}{$\begin{array}{l}\text { There will be a difference between the control and the intervention group in terms of change } \\
\text { mediators based on SCT. }\end{array}$} \\
\hline Nutrition Knowledge & $\mathrm{P}=<0.001$ & Fail to Reject \\
\hline \multicolumn{3}{|l|}{ Social Support } \\
\hline - Eating Habits \& Family Support & $\mathrm{P}=.037^{*}$ & Fail to Reject \\
\hline - Eating Habits \& Friends Support & $\mathrm{P}=.755$ & Reject \\
\hline - Exercise \& Family Support & $\mathrm{P}=.014^{*}$ & Fail to Reject \\
\hline - Exercise \& Friends Support & $\mathrm{P}=.149$ & Reject \\
\hline \multicolumn{3}{|l|}{ Self-Efficacy } \\
\hline - Eating Habits & $\mathrm{P}=.034^{*}$ & Fail to Reject \\
\hline - Exercise & $\mathrm{P}=.0018$ & Fail to Reject \\
\hline
\end{tabular}




\begin{tabular}{|c|c|c|}
\hline Hypothesis 2: & Findings & Decision \\
\hline \multicolumn{3}{|c|}{$\begin{array}{l}\text { A combination of SM and self-monitoring app will significantly increase fruits and vegetables } \\
\text { intake among Saudi Arabian female college students. }\end{array}$} \\
\hline Pre-Post Test: & $\mathrm{P}=.271$ & Reject \\
\hline Post-Follow up Test: & $\mathrm{P}=.33$ & Reject \\
\hline Hypothesis 3: & Findings & Decision \\
\hline \multicolumn{3}{|c|}{$\begin{array}{l}\text { A combination of SM and self-monitoring app will significantly increase physical activity among } \\
\text { Saudi Arabian female college students. }\end{array}$} \\
\hline Pre-Post Test: & $\mathrm{P}=.50$ & Reject \\
\hline Post-Follow up Test: & $\mathrm{P}=.55$ & Reject \\
\hline Hypothesis 4: & Findings & Decision \\
\hline \multicolumn{3}{|c|}{$\begin{array}{l}\text { A combination of SM and self-monitoring app will significantly prevent weight gain among Saud } \\
\text { Arabian female college students. }\end{array}$} \\
\hline Pre-Post Test: & $\mathrm{P}=.54$ & Reject \\
\hline Post-Follow up Test: & $\mathrm{P}=.62$ & Reject \\
\hline
\end{tabular}

$* \mathrm{P}<0.05$ 


\section{CHAPTER V}

\section{DISCUSSION}

The purpose of the current study was to develop and examine the feasibility of an obesity-prevention program delivered by SM (Instagram) and a mobile self-monitoring app (mDiet) among female college students as well as the effect of the utilization of these apps on various outcomes including physical activity, fruits and vegetables intake, and body weight. Three aims were identified: First, to determine the effectiveness of the intervention components on SCT constructs including, nutrition knowledge, social support, and self-efficacy. Second, to determine the effect of using social media along with self-tracing app on increasing fruits and vegetables intake. Third, to examine the impact of using social media along with self-tracing app on increasing physical activity. Last, determine the effect of using social media along with self-tracing app on preventing weight gain among college students. Lastly, future directions are drawn.

\section{Summary of the Study}

The intervention was based on social cognitive theory, which has been previously used to improve diet and physical activity behaviors and resulted in a substantial BW reduction. The current study aimed to increase 5 main SCT constructs including awareness, social support, self-monitoring, and self-regulation. Increasing those constructs would predict increases in individual's self-efficacy. Our findings suggest that increasing self-efficacy led to improvements in fruits and vegetables intake and physical activity, therefore, preventing weight control. 
Students were recruited from Princess Nourah bint Abdulrahman University, Riyadh, KSA. To be eligible for the current study they had to meet the eligibility criteria and complete the online survey. The total sample consisted of 103 students. They were randomly assigned to an intervention group (55) or a control group (48).

Participants in both groups were asked to complete the online questionnaire before randomization. This questionnaire consisted of basic demographic questions, health indicator items, social network usage, and several scales that included nutrition knowledge, which was modified based on the intervention topics; physical activity, to measure activity level; family and friends support, to measure their effective role on eating and exercise behaviors; eating habits confidence scale, to measure individual's self-efficacy; exercise confidence scale, to measure individual's self-efficacy.

Based on social cognitive theory, two feasibility studies of the research design and four hypotheses were developed to learn more about the effect of social media and self-tracking app, and how they can change lifestyle behaviors and, therefore, reduce body weight. The feasibility studies were used to assess the feasibility of the intervention design by retention and individual's satisfaction. The research hypotheses predicted several outcomes. First, The intervention program, which based on SCT, would increase nutrition awareness, social support, self-monitoring, self-regulation, and self-efficacy, which therefore might change lifestyle behaviors. Second, students in the intervention group would report higher intake of fruits and vegetables than students in the control group. Third, students in the intervention group were predicted to increase their physical activity score compared with their peers in the control group. Lastly, students in the 
intervention group were expected to reduce their body weight compared with students in the control group.

The results of this study provided support for the assumptions of the first feasibility study, indicating that $60 \%$ of students completed post intervention. The second feasibility study demonstrated that the participants in the intervention were effectively engaged by providing a number of likes, comments, and share in Instagram and by indicating strong satisfaction with intervention goals, content and format”. The three outcome hypotheses were not supported; however, changes in mediators suggest promising results for future interventions.

The study suffered from $31 \%$ drop-out rate at post intervention. Dropout rate is a major difficulty in weight gain prevention studies and can potentially bias the results. ${ }^{72}$ Common drop-out rates in Web-based interventions for weight loss are greater than $20 \% .^{73}$ The current study's drop-out rate is slightly higher than in these studies. However, in this study, dropout was not equal between the two groups. At post intervention, the dropout rate in the intervention group was $\sim 21 \%$, while the dropout rate in the control groups was $\sim 39 \%$. This unequal dropout rates between the groups is likely to be intervention-related. The control group did not receive any treatments in the current study. This might lead to loss of interest to continue participating in the study.

When comparing completers with noncompleters there were no significant differences in demographics, SCT mediators or outcomes. However, the noncompleters in the current study reported slightly less in nutrition knowledge scores, family and friend social support and eating, family but not friend social support an exercise, self-efficacy 
with eating habits and exercise scores (Table 14). The non-completers were also more likely to eat less fruits and vegetables, to exercise, and had lower body weight (Table 15). Literature has shown mixed results with regard to drop-out and initial body weight and a review of the behavioral approach to weight reduction reports that both a higher and lower initial BMI have been linked to drop-out in weight reduction studies. ${ }^{74}$

\section{Discussion of the Hypotheses}

The feasibility 1 study of the research design demonstrated that baseline recruitment of 100 students, assuming $60 \%$ retention (with complete data) at post-test and $50 \%$ retention (with complete data) at follow-up was partially possible. About $60 \%$ students completed the post intervention assessment. These results are supported by previous literature, which indicated that $30 \%$ drop-out rate happened at post intervention. However, the drop-out rate was high at follow up. This is further discussed in the feasibility design.

The Feasibility 2 study on the potential for the intervention to engage participants demonstrated that participants engaged by providing a number of likes, comments, and share in Instagram and strong satisfaction with intervention goals, content and format. The results show that $100 \%$ of the students in the intervention group found the intervention helpful and interesting. A hundred percent reported that they would encourage their friends to participate in such a program in the future. This confirmed a previous study that tested the social media Facebook to deliver a weight loss program to college students. ${ }^{19}$ About $97 \%$ of the participants found the program helpful and $100 \%$ of them would recommend the program to others. 
Hypothesis 1: There will be a difference between the control and the intervention group in terms of change mediators based on SCT. The intervention group will report higher nutrition knowledge, family and friend social support for eating and exercise, selfefficacy for eating and self-efficacy for exercise than the control group post intervention.

Social cognitive theory was manipulated in the current study in the development of the intervention component. The 5 constructs that were used were nutrition awareness/knowledge, social support, self-monitoring, and self-regulation. These 4 constructs were used to emphasize self-efficacy, which therefore would lead to behavioral changes.

At pre and post intervention, the intervention group significantly increased nutrition knowledge $(\mathrm{p}<.05)$, family social support and eating habits $(\mathrm{p}<.05)$ and exercise habits $(\mathrm{p}<.05)$, but not family and friends support with either eating habits or with physical activity $(\mathrm{p}>.05)$. Moreover, the intervention group was significantly increased eating habits and exercise self-efficacy $(\mathrm{P}<.05)$. Therefore, the hypothesis\#1 was supported, except friends social support scale.

Hypothesis 2: There will be a difference between the control and the intervention group in terms of fruits and vegetables consumption. The intervention group will report higher fruits and vegetables intake than the control group post intervention and increase or stay the same at follow up.

Although a self-tracking app previously increased fruits and vegetables intake among college students in 7 weeks, ${ }^{40}$ in the current study mDiet app was not effective enough to produce significant results. Fruits and vegetables intake increased in the 
intervention group, but was not statistically significant. Dietary intakes were self-reported and the researchers did not validate food intake. This could lead to under and/or overestimation of the intake of fruits and vegetables.

Hypothesis 3: There will be a difference between the control and the intervention group in terms of physical activity. The intervention group will report physical activity level higher than the control group.

Along with a previous study that examined the efficacy of social media Facebook, in conjunction with physical activity and a self-monitoring website among the same subjects, ${ }^{35}$ the current study did not find significant changes in physical activity between the two groups. The use of a self-report PA measure, small sample size, and short duration of the study could have affected the results.

Hypothesis 4: There will be a difference between the control and the intervention groups in body weight. The intervention group will experience reduction or maintenance in body weight, while the control group will gain weight.

In contrast to the Napolitano and colleagues study, ${ }^{19}$ that was also conducted a study among college students, the current study could not detect a statistically significant change between the two study groups in body weight at post Wilks' Lambda= .99 , $\mathrm{F}(1,70)=.39, \mathrm{p}>.05$ (Table 20) and follow-up Wilks' Lambda $=.99, \mathrm{~F}(1,26)=.26, \mathrm{p}>.05$ (Table 21) assessment. Napolitano et al. ${ }^{19}$ used Facebook in conjunction with access to healthy activities. At 4 and 8 weeks, the Facebook plus group experienced the greatest weight loss at $\sim-1.7 \mathrm{~kg}$ and $\sim-2.5 \mathrm{~kg}$, respectively and the changes in BW among the groups were statistically significant. In the current study, participants in the intervention 
group lost -1 kg and -.7 kg at 6 and 10 weeks, respectively. Consistent with our findings, a Twitter study found that this social media was also not effective in reducing $\mathrm{BW} .{ }^{40}$ After 6 months, the researchers observed minimal weight changes in both groups $(\sim 0.25 \mathrm{~kg})$ without a difference between the groups. This gives some evidence that delivering weight-related health behavior content vie social media platform in addition to a self-tracking app may not be enough to drive body weight loss in particular. In contrast with the Twitter research, the goal of our current study was to prevent weight gain, which was more realistic for the length of time of our study's follow-up.

\section{Discussion of Study Design}

\section{Discussion of Methodology}

To our knowledge, this randomized controlled trial study is the first to demonstrate the feasibility of using Instagram to deliver a program to prevent weight gain in college students in Saudi Arabia. The data indicated that a combination of social media and self-tracking app prevent weight gain. Moreover, such method produced significantly improvement in nutrition knowledge, social family social support, and eating and exercised self-efficacy post-intervention. No changes were found for study outcome behaviors such as fruit and vegetable intake or physical activity. This type of intervention delivery, mobile-based, can be affordably and easily delivered to a large number of individuals.

The current study aims to prevent weight gain among female college students by using social and self-tracking app to educate, motivate, and change behaviors that support weight reduction and healthy weight control. Students in the current study did not show a 
significant body weight reduction; this might be because the time of year when the study was conducted may have affected the outcomes. During the first 6 weeks, the students had their midterms, while the 10-week follow up occurred over the summer break and month of Ramadan a time when dietary behaviors change considerably. Findings from this study will add to the growing research literature on how technology and social networks can be used to increase PA and fruit and vegetable intake, two behaviors important for body weight control. Additionally, this study may yield further insights into the relationships between social media use, social support, and health behaviors. Social media has been shown to be a promising venue for health promotion given its ubiquity and that users can share their experiences in real-time. ${ }^{64,65}$ Though social media platform has been shown to improve self-esteem ${ }^{64-68}$ and life satisfaction ${ }^{68,69}$ there is limited evidence regarding its benefit on health behaviors, ${ }^{35}$ in particular from prospective studies.

Self-monitoring of dietary intake regardless of the methods, have been shown to be effective in changing lifestyle behaviors. ${ }^{19,36,36,38}$ The current study used one of the current self-monitoring apps widely available to the Arabic population. The study used mDiet in particular because it is the only app found in Arabic. All students (100\%) in the intervention group reported that using self-tracking app helped them think about food portion sizes.

Social support has been show to be a key component in behavioral weightreduction programs. ${ }^{75}$ The current study used Instagram as a method to deliver the nutrition and physical activity intervention and allow students to support each other during their lifestyle changes efforts. The study investigators posted 1-2 posts per day and 
encouraged the student to interact and posted students post to motivate the others to do the changes. Surprisingly, participants in the Instagram group in the current study reported significant nutrition and physical activity social support that they received from their family but not from their friends.

Results provided support for feasibility and acceptability regarding the use of delivering a nutrition and physical activity intervention to college students. Specifically, everyone $(100 \%)$ in the Instagram group found the study interested and helpful, $100 \%$ reported that the Instagram topics motivated them to consume fruits and vegetables, and $100 \%$ would encourage their friends and family to participate in such a program.

\section{Limitations}

Though this study has a number of strengths, there are several limitations that should be addressed as they may affect the generalizability and interpretation of these results. First, this study had a relatively small sample size $(\mathrm{N}=103)$, although the effects were large enough to detect significant differences among the groups. Drop-out rates were high at the 10-week follow-up. This is probably because of the summer and Ramadan month had started. Due to the probability that students leaving town for summer vacation along with Ramadan beginning, this may have influenced student diet and physical activity habits as many participate in fasting from sunrise to sundown during this time. In regard to the instrumentation used in the study, there have been some limitations. Students in the control group might have had friends in the control group. Therefore, they might have been cross-contamination that exposed controls to some of the intervention. 
Moreover, all of the information was self-reported, except anthropometrics at baseline and post intervention. Self-reported data have numerous advantages including its practicality, cost-effectiveness and ease of administration. ${ }^{70}$ Yet, there are several limitations to self- reported data, such as participants' ability to accurately recall past events, response bias, and social desirability. ${ }^{71}$ Accordingly, perceived actions may be different than actual behaviors.

The study has some strengths. First, it was fully online. Students in both groups were asked to complete the survey online. They were able to complete the survey anytime and open it several time to finish it. Second, this was a randomized control trial with comparable participants in both the intervention and control groups. Third, this kind of intervention is a cost-effective treatment for weight related behaviors and could be beneficial in reducing obesity epidemic. Nowadays, there are many weight loss apps and they are free or reasonable price and can provide a very cost effective way to encourage adherence to a weight reduction plan. Additionally, compare to face-to-face method, technology-based interventions may have a greater potential to reach large numbers of individuals and make a public health influence. Lastly, this study had a strong theoretical design, which may have contributed to the results seen in the mediators.

\section{Future Directions:}

The current study provided promising results in changing mediators of health behaviors in college students. Longer studies with higher sample sizes are needed to determine efficacy in changing health behaviors. Researchers need to determine strategies to deal with long-term engagement with these platforms. Future research is 
needed to determine the level of continued engagement and utilization of the platforms, as well as sustainability of weight control or weight loss. However, from a public health standpoint, even preventing weight gain or achieving small to modest weight loss due to knowledge that is disseminated on broad scale could have a positive effect on population health. 


\section{LIST OF REFERENCES}

1. Obesity research center. http://www.obesitycenter.edu.sa/Patients---Public/Obesityin-saudi-Arabia.aspx. Accessed March 18, 2017.

2. Musaiger AO. Overweight and Obesity in the Arab Countries: the Need for Action, http://acnut.com/v/images/stories/pdf/overweight_and_obesity_in_arab_countries.pdf .Accessed March 02, 2017.

3. Memish ZA, El Bcheraoui C, Tuffaha M, Robinson M, Daoud F, Jaber S, et al. Obesity and Associated Factors - Kingdom of Saudi Arabia, 2013. Preventing Chronic Disease. 2014;11:e174.

4. FAO/WHO Technical Consultation on National Food-Based Dietary Guidelines. http://www.who.int/nutrition/publications/nutrientrequirements/dietguide_emro/en/. Accessed February 01, 2017.

5. Arab Center for Nutrition. Nutrition Situation in the Arab Countries. Manama, Bahrain; 2009.

6. Center for Disease Control and Prevention. How many fruits and vegetables do you need? http://www.fruitsandveggiesmorematters.org/wpcontent/uploads/UserFiles/File/pdf/resources/cdc/HowMany_Brochure.pdf. Accessed March 28, 2017.

7. Bcheraoui CE, Basulaiman M, AlMazroa MA, Tuffaha M, Daoud F et al. Fruit and vegetable consumption among adults in Saudi Arabia, 2013. Nutrition and Dietary Supplements. 2015;7:41-49.

8. World Health Organization. Promoting fruit and vegetable consumption around the world. http://www.who.int/dietphysicalactivity/fruit/en/. Accessed January 29, 2017.

9. Al-Hazzaa HM. The public health burden of physical inactivity in Saudi Arabia. Journal of Family \& Community Medicine. 2004;11(2):45-51.

10. Al-Eisa ES and Al-Sobayel HI. Physical activity and health beliefs among Saudi women. Journal of Nutrition and Metabolism. 2012.

11. Khalaf A, Ekblom Ö, Kowalski J, Berggren V, Westergren A, Al-Hazzaa H. Female university students' physical activity levels and associated factors: a cross-sectional study in south- western Saudi Arabia. International Journal of Environmental Research and Public Health. 2013;10(8):3502-17.

12. Kelishadi R. Childhood overweight, obesity and the metabolic syndrome in developing countries. Epidemiological Review. 2007;29:62-76. 
13. World Health Organization. Global strategy on diet, physical activity and health. Physical activity and adults. Recommended levels of physical activity for adults aged 18-64 years. http://www.who.int/dietphysicalactivity/factsheet_adults/en/. Accessed October 4, 2016.

14. El Bcheraoui C, Tuffaha M, Daoud F, Kravitz H, Al Mazroa MA, Al Saeedi M et al. On Your Mark, Get Set, Go: Levels of Physical Activity in the Kingdom of Saudi Arabia, 2013. Journal of Physical Activity and Health. 2016;13:231-238.

15. Anderson DA, Shapiro JR, Lundgren JD. The freshman year of college as a critical period for weight gain: an initial evaluation. Eating Behaviors. 2003;4:363-367.

16. Patrick K, Marshall SJ, Davila EP, Kolodziejczyk JK, Fowler JH, et al. Design and implementation of a randomized controlled social and mobile weight loss trial for young adults (project SMART). Contemporary Clinical Trials. 2014;37(1):10-8.

17. Hill JO, Wyatt HR, Reed GW, Peters JC. Obesity and the environment: where do we go from here? Science. 2003;299:853-855.

18. Khalaf A, Westergren A, Berggren V, Ekblom O, Al-Hazzaa HM. Prevalence and association of female weight status and dietary habits with sociodemographic factors: a cross-sectional study in Saudi Arabia. Public Health Nutrition. 2015;18(5):784-96.

19. Napolitano MA. Using facebook and text messaging to deliver a weight loss program to college students. Obesity (Silver Spring, Md.). 2013;21(1):25-30.

20. Hegazy AA, Alkhail BA, Awadalla NJ, Qadi M, Al-Ahmadi J. Mobile Phone Use and Risk of Adverse Health Impacts among Medical Students in Jeddah, Saudi Arabia.

British Journal of Medicine and Medical Research. 2016;15(1):1-11.

21. Kowalczyk K. Instagram and Facebook users in Saudi Arabia - May 2016. https://napoleoncat.com/blog/en/instagram-and-facebook-users-in-saudi-arabia-may2016/. Accessed February 28, 2017.

22. Oh HJ, Lauckner C, Boehmer J, Fewins-Bliss R, Li K. Facebooking for health: An examination into the solicitation and effects of health-related social support on social networking sites. Computers in Human Behavior. 2013;29:2072-2080.

23. McFerran B, Dahl DW, Fitzsimons GJ, Morales AC. I'll have what she's having: Effects of social influence and body type on the food choices of others. Journal of Consumer Research. 2010;36:915-929.

24. McCarroll ML, Armbruster S, Pohle-Krauza RJ, Lyzen AM, Min S, Nash DW, et al. Feasibility of a lifestyle intervention for overweight/obese endometrial and breast cancer survivors using an interactive mobile application. Gynecologic Oncology. 2015;137: 508-515. 
25. Fukuoka Y, Gay CL, Joiner KL, Vittinghoff E. A Novel Diabetes Prevention Intervention Using a Mobile App: A Randomized Controlled Trial With Overweight Adults at Risk. American Journal of Preventive Medicine. 2015;49(2):223-237.

26. Bandura A. Social Foundations of Thought and Action: A Social Cognitive Theory. Prentice Hall; Englewood Cliffs, NJ: 1986.

27. Anderson-Bill ES, Winett RA, Wojcik JR, Winett SG. Web-based guide to health: relationship of theoretical variables to change in physical activity, nutrition and weight at 16-months. Journal of Medical Internet Research. 2011;13(1).

28. Nelson MC, Story M, Larson NI, Neumark-Sztainer D, Lytle LA. Emerging adulthood and college-aged youth: an overlooked age for weight-related behavior change. Obesity. 2008;16:2205-2211.

29. Silliman K, Rodas-Fortier K, Neyman M: A survey of dietary and exercise habits and perceived barriers to following a healthy lifestyle in a college population. Californian Journal of Health Promotion. 2004;2(2):10-19.

30. Holm-Denoma JM, Joiner TE, Vohs KD, et al. The "freshman fifteen" (the "freshman five" actually): predictors and possible explanations. Health Psychology Journal. 2008;27:S3-9.

31. Vella-Zarb RA, Elgar FJ. The "freshman 5": a meta-analysis of weight gain in the freshman year of college. Journal of American College Health. 2009;58:161-166.

32. Reed JA, Philips DA. Relationships between physical activity and the proximity of exercise facilities and home exercise equipment used by undergraduate university students. Journal of American College Health. 2005;53:285-290.

33. Srinivasan SR, Bao W, Wattigney WA, Berenson GS. Adolescent overweight is associated with adult overweight and is related to multiple cardiovascular risk factors: the Bogalusa Heart Study. Metabolism Clinical and Experimental. 1996;45:235-240.

34. Field AE, Coakley EH, Must A, et al. Impact of overweight on the risk of developing common chronic diseases during a 10-year period. Archives of Internal Medicine. 2001;161:1581-1586.

35. Cavallo DN. A social Media-Based physical activity intervention. American Journal of Preventive Medicine. 2012;43(5):527-532.

36. Valle CG, Tate DF, Mayer DK, Allicock M, Cai J. A randomized trial of a Facebookbased physical activity intervention for young adult cancer survivors. Jouranl of Cancer Survivorship. 2013;7:355-368 
37. Carter MC, Burley VJ, Nykjaer C, Code JE. Adherence to a smartphone application for weight loss compared to website and paper diary: pilot randomized controlled trial. Jouranl of Medical Internet Research. 2013;15(4):e32.

38. Cunningham B, Warton C, Johnson C, Hall R. Smart Phones and Dietary Tracking: A Feasibility Study [thesis]. Tempe, AZ: Arizona State University; 2011.

39. Hebden L, Cook A, van der Ploeg HP, King L, Baumant A, Allman-Farinelli M. A mobile health intervention for weight management among young adults: a pilot randomised controlled trial. Journal of Human Nutrition and Dietetics. 2013;27:322332.

40. Brown ON, O’Connor LE, Savaiano D. Mobile MyPlate: A Pilot Study Using Text Messaging to Provide Nutrition Education and Promote Better Dietary Choices in College Students. Journal of American College Health 2014;62(5):320-327.

41. Vaterlaus JM, Patten EV, Roche C, Young JA. \#Gettinghealthy: The perceived influence of social media on young adult health behaviors. Computer in Human Behavior. 2015;45:151-157.

42. Coyne SM, Padilla-Walker LM, Howard E. Emerging in a digital world a decade review of media use, effects, and gratifications in emerging adulthood. Emerging Adulthood. 2013;1(2):125-137.

43. Alloy Media \& Marketing. (2009). 9th annual college explorer survey. <http:// www.marketingcharts.com/television/college-students-spend-12-hoursday- withmedia-gadgets-11195/>. 2009. Accessed November 4, 2016.

44. Kaiser Family Foundation. Generation M2: Media in the lives of 8- to 18-year olds. 2010. Accessed November 6, 2016.

45. Pew Research Center. Social networking fact sheet. PewResearch Internet Project. http://www.pewinternet.org/fact-sheets/social-networking-fact-sheet/. 2014. Accessed January 29, 2017.

46. Duggan, M. Photo and video sharing grow online. PewResearch Internet Project. http://www.pewinternet.org/2013/10/28/photo-and-video-sharing- grow-online/. 2013. Accessed March 31, 2017.

47. Instagram. https://www.instagram.com. Accessed February 16, 2017.

48. Rutsaert P, Regan Á, Pieniak Z, McConnon Á, Moss A, Wall P, et al. The use of social media in food risk and benefit communication. Trends in Food Science \& Technology. 2013;30:84-91. 
49. Turner-McGrievy G and Tate D. Tweets, Apps, and Pods: Results of the 6-Month Mobile Pounds O! Digitally (Mobile POD) Randomized Weight-Loss Intervention Among Adults. Journal of Medical Internet Research. 2011;13(4):e120.

50. Laing BY, Mangione CM, Tseng C-H, Leng M. Effectiveness of a Smartphone Application for Weight Loss Compared With Usual Care in Overweight Primary Care Patients. Annals of Internal Medicine. 2014;161:S5-S12.

51. Alhussain T, AlGhamdi R, Alkhalaf S, Alfarraj O. Users "e Perceptions of Mobile Phone Security: A Survey Study in the Kingdom of Saudi Arabia. International Journal of Computer Theory and Engineering. 2013;5.

52. Turner-McGrievy GM, Beets MW, Moore JB, Kaczynski AT, Barr-Anderson DJ, and Tate DF. Comparison of traditional versus mobile app self-monitoring of physical activity and dietary intake among overweight adults participating in an mHealth weight loss program. Journal of the American Medical Informatics Association. 2013;20(3):513-518.

53. Verheijden MW, Bakx JC, van Weel C, Koelen MA, van Staveren WA. Role of social support in lifestyle-focused weight management interventions. European Journal of Clinical Nutrition. 2005;59(1):179-186.

54. Bandura A. Self-efficacy: toward a unifying theory of behavioral change. Psychological Review. 1977;84(2):191-215.

55. Parmenter, K, \& Wardle J. Development of a general nutrition knowledge questionnaire for adults. European Journal of Clinical Nutrition. 1999;53:298-309.

56. Sallis JF, Grossman RM, Pinski RB, Patterson TL, Nader PR. The development of scales to measure social support for diet and exercise behaviors. Preventive Medicine. 1987;16(6):825-836.

57. Kiernan M, Moore SD, Schoffman DE et al. Social support for healthy behaviors: scale psychometrics and prediction of weight loss among women in a behavioral program. Obesity. 2012;20:756-764.

58. Clark MM, Abrams DB, Niaura RS, Eaton CA, Rossi JS. Self-efficacy in weight management. Journal of Consulting and Clinical Psychology. 1991;59(5):739-744.

59. Marcus BH, Selby VC, Niaura RS, Rossi JS. Self-efficacy and the stages of exercise behavior change. Research Quality of Exercise and Sport. 1992;63:60-66.

60. Godin G, Jobin J, Bouillon J. Assessment of leisure time exercise behavior by selfreport: a concurrent validity study. Canadian Journal of Public Health. 1986:77(5);359-362. 
61. Jones LW, Courneya KS, Fairey AS, Mackey JR. Effects of an oncologist's recommendation to exercise on self-reported exercise behavior in newly diagnosed breast cancer survivors: a single-blind, randomized controlled trial. Annals of Behavioral Medicine. 2004;28:105-113.

62. Rogers LQ, Hopkins-Price P, Vicari S, et al. A randomized trial to increase physical activity in breast cancer survivors. Medicine \& Science in Sports \& Exercie. 2009;41:935-946.

63. Von Gruenigen VE, Gibbons HE, Kavanagh MB, Janata JW, Lerner E, Courneya KS. A randomized trial of a lifestyle intervention in obese endometrial cancer survivors: quality of life out- comes and mediators of behavior change. Health and quality of Life Outcomes. 2009;7:17.

64. Buis, L.R. The potential for web-based social network sites and self-regulation for health promotion. American Journal of Health Promotion. 2011;26:73-76.

65. Bennett, G.G. and Glasgow, R.E. The delivery of public health interventions via the Internet: actualizing their potential. Annual Review of Public Health. 2009;30:273292.

66. Ellison, N., Steinfield, C., and Lampe, C. The benefits of Facebook 'friends': social capital and college students' use of online social network sites. Journal of ComputerMediated Communication. 2007;12:1143-1168.

67. Gonzales, A.L. and Hancock, J.T. Mirror, mirror on my Facebook wall: effects of exposure to Facebook on self-esteem. Cyberpsychology, Behavior and Social Networking. 2011;14:79-83.

68. Valkenburg, P.M., Peter, J., and Schouten, A.P. Friend networking sites and their relationship to adolescents' well-being and social self-esteem. Cyberpsychology Behavior. 2006;9:584-590.

69. Valenzuela, S., Park, N., and Kee, K. Is there social capital in a social network site?: Facebook use and college students' life satisfaction, trust, and participation. International Journal of Computers Communications \& Control. 2009;14:875-901.

70. Gorber, S.C., Trembly, M., Mother, D., Gorber, B. A comparison of direct vs. selfreport measures for assessing height, weight and body mass index: a systematic review. Journal Recommendation Service. 2007;8(4):307-326.

71. Singleton, R.A., Straits, B.C. Approaches to social research. New York, NY, US: Oxford University Press. 1988.

72. Ware, J.H. Interpreting incomplete data in studies of diet and weight loss. The New England Journal of Medicine. 2003;348(21):2136-2137. 
73. Neve, M, Morgan, P.J., Jones, P.R., and Collins, C.E. Effectiveness of web-based interventions in achieving weight loss and weight loss maintenance in overweight and obese adults: a systematic review with meta-analysis. Obesity Reviews.

2010;11(4):306-321.

74. Wing, R.P., Phelan, S. Obesity: Mechanisms and Clinical Management. Philadelphia, PA: Lippincott Williams \& Wilkins; 2003. Behavioral treatment of obesity: strategies to improve outcome and predictors of success; pp. 415-435.

75. Verheijden, M.W., Bakx, J.C., van Weel, C., Koelen, M.A., and van Staveren, W.A. Role of social support in lifestyle-focused weight management interventions.

Eurpoean Journal of Clinical Nutrition. 2005 Aug; 59(1):179-186. 


\section{APPENDICES}

Appendix 1.

Recruitment Flyer "English”

\section{CHALLENGE YOUR HEALTH IN 42 DAYS!}

The purpose of this project is to prevent weight gain among Saudi Arabian female college students by helping students improve their dietary behaviors and increase physical activity.

Participation in this project will require you to:

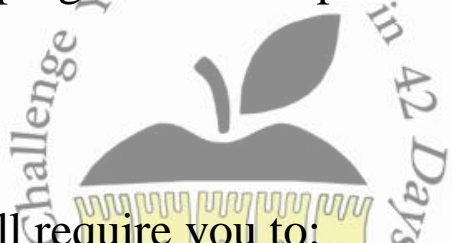

1. Attend 3 in-person sessions (15 minutes each)

2. Participants in the intervention group only:

a. Follow and participate in a social media based intervention using Instagram

i. You will be asked to log on to Instagram through your mobile device at least once daily to read study related messages posted, "like," "share," and/or "comment."

b. Utilize the self-monitoring application $\boldsymbol{m D i e t}$ daily.

This project will allow you to increase your own nutrition and physical activity knowledge, motivation and health messaging. You may also gain insights about sharing and exchanging content through social-networking sites. 
Recruitment Flyer "English”

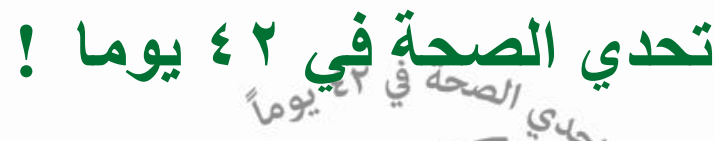

الغرض من هذه الدراسة هو منع زبيادة الوزن لاى طالبات الجامعة في المملكة العربية السعودية عن طريث تحسين السلوك الغذائي و زيادة الحركة.

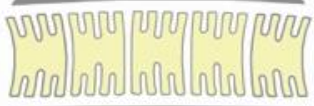

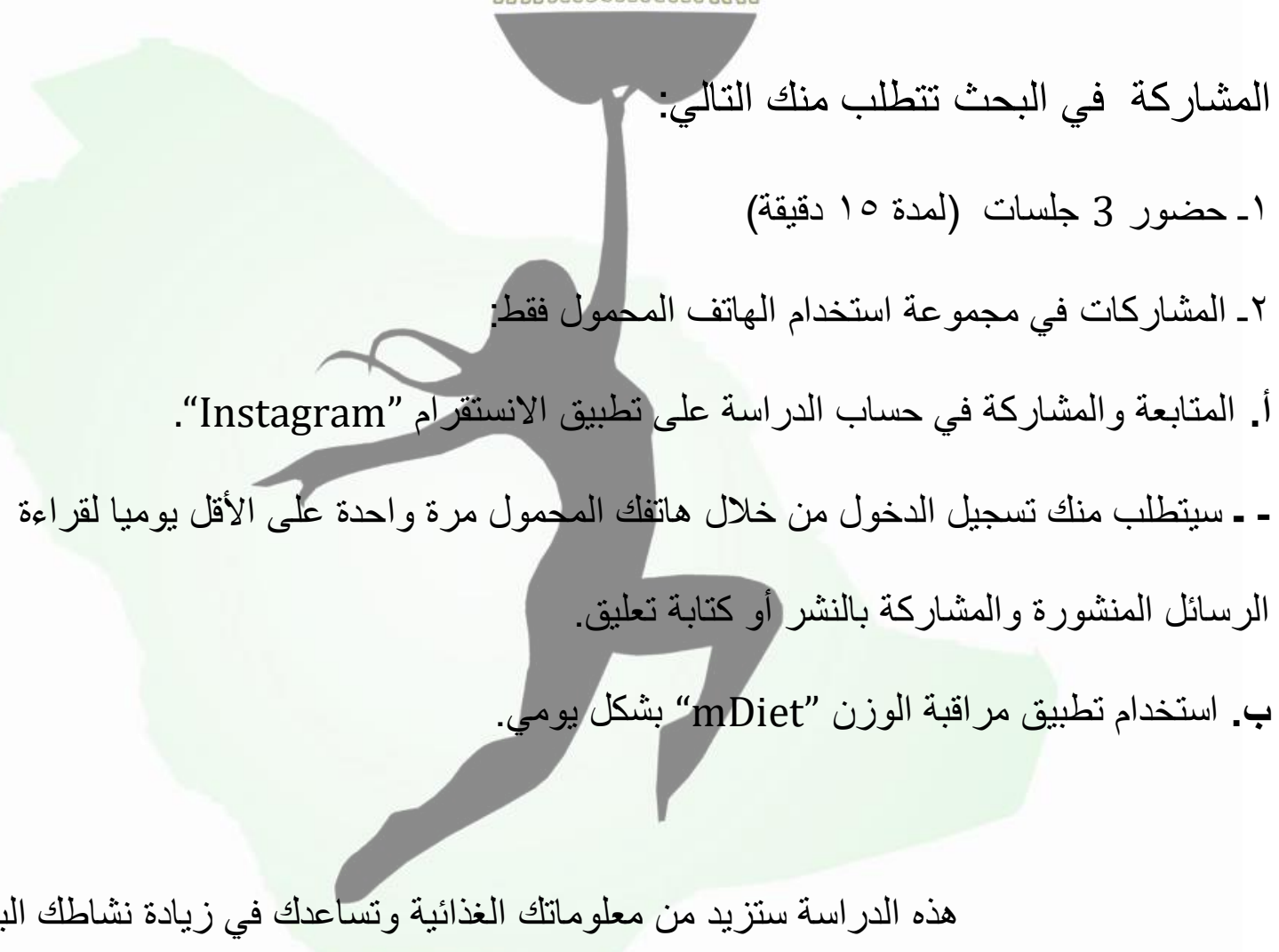

هذه الدراسة ستزيد من معلو ماتلك الغذائية وتساعدك في زيادة نشاطلك البدني.

في حالة الالتز ام بمتطلبات الدر اسة ستحصلين على ساعة تقوم بتسجيل

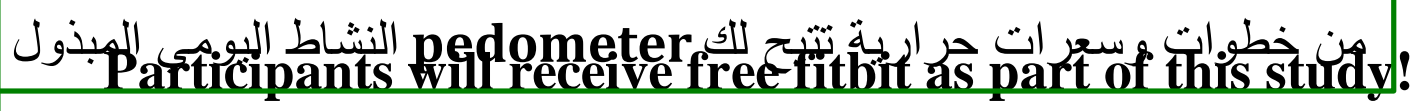


Appendix 2.

Consent Form "English”

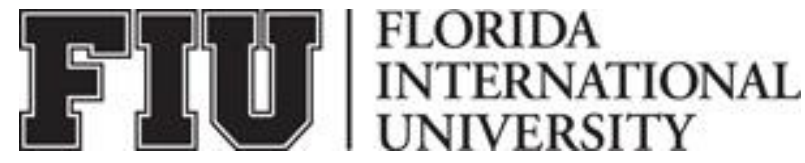

ADULT CONSENT TO PARTICIPATE IN A RESEARCH STUDY

A mobile-based intervention for obesity prevention among female college students in Saudi Arabia: A randomized controlled trial

\section{PURPOSE OF THE STUDY}

You are being asked to be in a research study that will be conducted at Princess Nourah bint Abdulrahman University in Riyadh. The purpose of this study is to develop and examine the feasibility of an obesity-prevention program delivered by social media and a mobile self-monitoring application.

\section{NUMBER OF STUDY PARTICIPANTS}

If you decide to be in this study, you will be one of 100 students in this research study.

\section{DURATION OF THE STUDY}

Your participation will require less than 5 minutes per day for 12 weeks, 45

minutes at baseline, and 15 minutes at 6 week and 12 week.

\section{PROCEDURES}

If you agree to be in the study, we will ask you to do the following things:

1. Complete an online screening form to determine eligibility via Qualtrics.

2. Attend 3 in-person sessions

a. Orientation session ( $\sim 45$ minutes)- at baseline

i. Learn more about the project

ii. Review informed consent

iii. Receive a link for an online survey (30-45 minutes)

iv. Anthropometric measurements such as height, weight, and waist circumference will be collected

b. Intervention completion ( $\sim 15$ minutes)- at week 6

i. Receive a link for an online survey (30-45 minutes)

ii. Anthropometric measurements such as height, weight and waist circumference will be collected

c. Program completion ( 15 minutes)- at week12

i. Receive a link for an online survey (30-45 minutes) 
ii. Anthropometric measurements such as height, weight and waist circumference will be collected

3. Participants in the intervention group only:

a. Follow and participate in a social media based intervention using Instagram

i. You will be asked to log on through your mobile device at least once daily to read messages posted, "like," "share," and/or "comment."

b. Utilize the self-monitoring application mDiet daily.

\section{RISKS AND/OR DISCOMFORTS}

Potential discomfort may be experienced by subjects due to required use of a publicaccessed social networking site, Instagram. Risks compared to anticipated benefits are negligible. Subjects' potential benefits out-weight the risks. Knowledge related to the outcomes of this study could potentially provide insight into the feasibility of the use of social networking sites as platforms for health-behavior interventions.

\section{BENEFITS}

The following benefits may be associated with your participation in this study:

1. This project will allow you to increase your own nutrition and physical activity knowledge, motivation and health messaging.

2. You may also gain insights about sharing and exchanging content through social-networking sites.

3. The prevalence of obesity in Saudi Arabia can be reduced in a cost-effective method.

\section{ALTERNATIVES}

There are no known alternatives available to you other than not taking part in this study. However, any significant new findings developed during the course of the research which may relate to your willingness to continue participation will be provided to you.

\section{CONFIDENTIALITY}

The records of this study will be kept private and will be protected to the fullest extent provided by law. In any sort of report we might publish, we will not include any information that will make it possible to identify a subject. Research records will be stored securely and only the researcher team will have access to the records. However, your records may be reviewed for audit purposes by authorized University or other agents who will be bound by the same provisions of confidentiality.

\section{COMPENSATION \& COSTS}

You will receive a pedometer if you participate to the end of the study. If you are fully engaged in the study, there will be a random selection on a weekly basis to 
receive a gift card. Each week there will be a winner. You will not be responsible for any costs to participate in this study.

\section{RIGHT TO DECLINE OR WITHDRAW}

Your participation in this study is voluntary. You are free to participate in the study or withdraw your consent at any time during the study. Your withdrawal or lack of participation will not affect any benefits to which you are otherwise entitled. The investigator reserves the right to remove you without your consent at such time that they feel it is in the best interest.

\section{RESEARCHER CONTACT INFORMATION}

If you have any questions about the purpose, procedures, or any other issues relating to this research study you may contact Abeer Alssafi at 0500205552, aalss001@fiu.edu or Catherine Coccia, Ph.D., R.D. at 3053480194, ccoccia@fiu.edu.

\section{IRB CONTACT INFORMATION}

If you would like to talk with someone about your rights of being a subject in this research study or about ethical issues with this research study, you may contact the FIU Office of Research Integrity by phone at 305-348-2494 or by email at ori@fiu.edu.

\section{PARTICIPANT AGREEMENT}

I have read the information in this consent form and agree to participate in this study. I have had a chance to ask any questions I have about this study, and they have been answered for me. I understand that I will be given a copy of this form for my records.

Signature of Participant

Printed Name of Participant

Signature of Person Obtaining Consent

\section{Date}

Date 


\section{Appendix 3.}

\section{Consent Form "Arabic"}
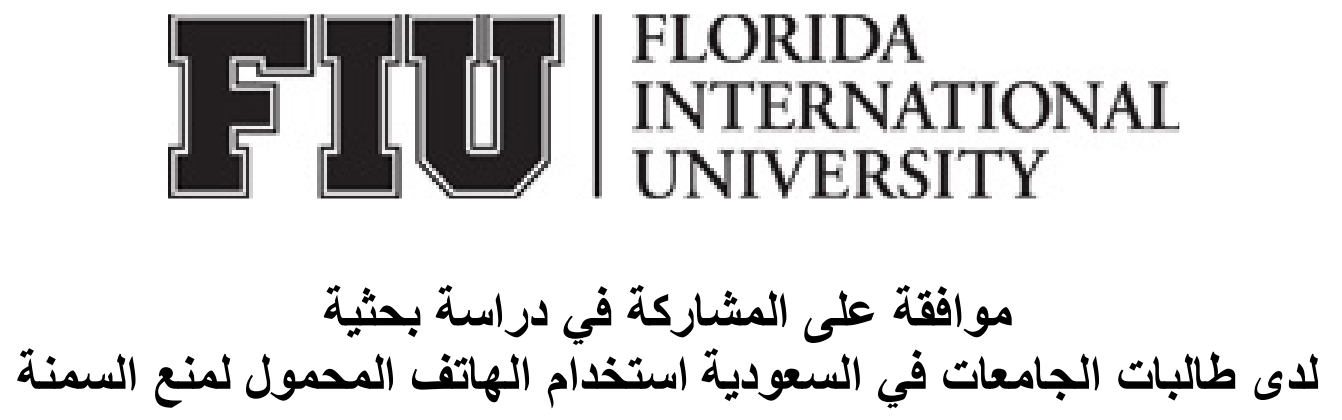

$$
\text { الهذف من الاراسة }
$$

أنت مدعو للمشاركة في بحث علمي سيجرى في جامعة الأميرة نورة بنت عبدالرحمن في الرياض. الغرض من هذه الدراسة البحثية هو تطوير ودر اسة جدوى لبرنامج الوقاية من السمنة عن طريق استخدام وسائل التو اصل الاجتماعي وتطبيق مر اقبة لرئة الوزن لدى طالبات الجامعة.

$$
\text { عداد المشاركات في الاراسة }
$$

إذا قررت أن تشاركي في هذه الدر اسة ستكونين و احدة من 100 طالبة في هذه الدراسة البحثية.

سوف يتطلب منك حضور جلسة تعريفية لمدة 45 دقيقة وجلستين في الأسبو عين السادس و الثاني عثر مدتهما 15 دقيقة، أيضا سيتطلب منك المشاركة أقل من 5 دقائق لمدة 12 أسبو عا.

إجراءات تطبيقية في حاله الموافقه على المشاركه في هذه الاراسه سوف يطلب منك الاتي: 1- إكمال استبيان مبدئي عبر الانترنت لتحديد الأهلية عبر تطبيق كواتركس "Qualtrics". 2- حضور 3 جلسات المذكورة أدناه: أ. في الاسبوع الأول: جلسة تعريفية (لمدة 45 دقيقة) تتضمن الآتي: ـ التعرف على المزيد حول الدراسة. - مر اجعة نموذج المو افقة في المشاركة في البحث. ـ تلقي رابط عبر البريد الالكتروني لاستبيان واحد عبر الانترنت (لمدة 30 دقيقة). - جمع قياسات الطول و الوزن ومحيط الخصر . ب. في الأسبوع السادس: جلسة الانتهاء من نطبيق الدراسة (لمدة 15 دقيقة) وتتضمن: 
ـ تلقي رابط عبر البريد الالكتروني لإجر اء استبيان واحد عبر الانترنت (لمدة 15 دقيقة).

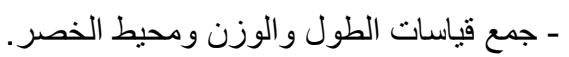
جـ. في الأسبوع الثاني عشر: جلسة المتابعة (لمدة 15 دقيقة) وتتضمن: ـ تلقي رابط عبر البريد الالكتروني لإجر اء استبيان واحد عبر الانترنت (لمدة 15 دقيقة).

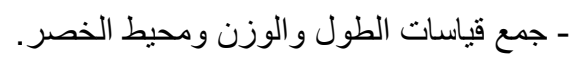
3- المشاركات في مجموعة استخدام الهاتف المحمول فقط:

أ. المتابعة والمشاركة في حساب الدراسة على نطبيق الانستقرام "Instagram". ـ سيطلب منك تسجيل الدخول من خلال هاتفاك المحمول مرة واحدة على الأقل يوميا لقر اءة الرسائل المنشورة و المشاركة بالنشر أو كتابة تعليق.

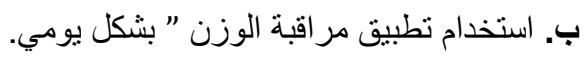

الآثار الجانبية المتوقعة لا نوجد آثار جانبية معروفة مرتبطة بإجراءات الدراسة. قد يكون هناك شعور بعدم الراحة المحتمل من قبل المشاركات بسبب

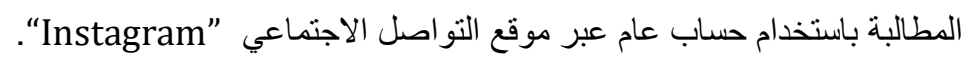
الفوائد الناتجة عن الاراسة 1- هذه الدر اسة ستزيد من معلوماتك الغذائية وتساعدك في زيادة نشاطلك البدني. 2- 2 تقليل نسبة السمنة في السعودية بأقل تكلفة ممكنة.

\section{سياسة الخصوصية}

سيتم المحافظة في كافة الأوقات على خصوصية وسرية كافة البيانات الثخصية التي نحصل علهيا. ولن ينم إفنشاء هذه المعلومات إلا إذا كان ذللك مطلوبا بموجب قانون الجامعات السعودية المعترف بها. ولن يتم نشر معلومات قد تجعل من الممكن

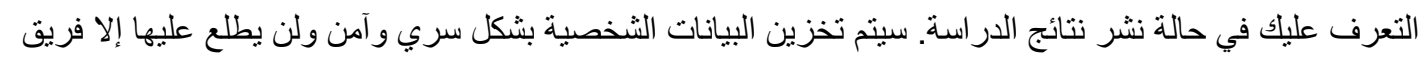

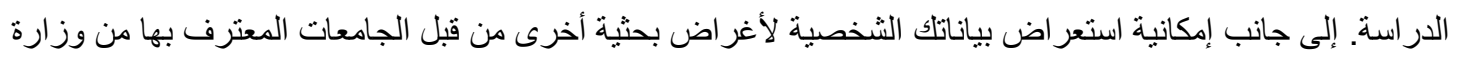
التعليم العالي السعودي

\section{التكاليف المادية والحوافز}

لن تكوني مسؤولة عن صرف أي مبالغ مادية للمشاركة في هذه الدراسة.

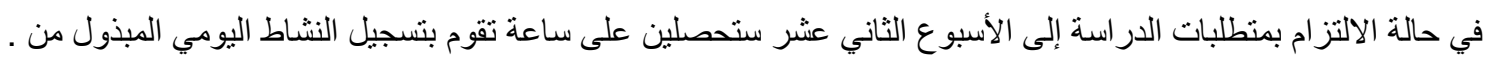

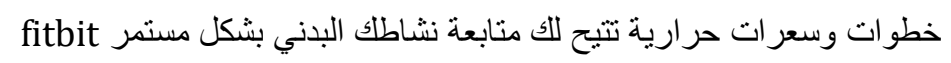
إضافة إلى ذلك سيكون هناك جو ائز أسبو عية تحفيزية عبارة عن بطاقات مسبقة (Gift cards) و التي سيكون عليها سحب الدفع عشو ائي من مجموع المشاركات الملتزمات بالدر اسة. 
الحق في الرفض أو الانسحاب

مشاركتلك في هذه الدر اسة تطو عية وكل كامل الأحقية في الانسحاب في أب وقت أثناء الدراسة. إن انسحابك أو عدم مشاركتابك

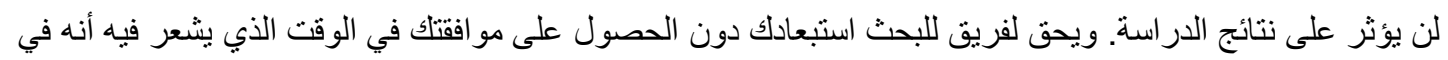
مصلحة

\section{معلومات الاتصال بفريق البحث}

إذا كان لديك أي أسئلة حول الغرض من الدراسة أو الإجراءات المتخذة أو أية مواضيع أخرى تتعلق بهذه الدراسة يمكنك التو اصل مع : aalss001@fiu.edu ,05002055525 عبير الصافي: _ -

\section{معلومات الاتصال بلجنة الأخلاقيات والبحوث الطبية}

إذا كنت تر غبين بالتحدث مع شخص ما حول حقوقلك كشاركة في هذه الدر اسة البحثية أو حول القضايا الأخلاقية مع هذه الدراسة، يمكنك الاتصال بجامعة فلوريدا العالمية لسلامة البحوث عن طريق الهاتف 3053482494 أو عن طريق البريد ori@fiu.edu الالكتروني

الموافقة على المشاركة

أقر أن الموقع أدناه بأنني قرأت كافة المعلومات في هذا النموذج وأوافق على المشاركة في هذه الدراسة، ولقد أتيحت لي الفرصة لطرح أي أسئلة تتعلق بالدر اسة وقد تم الرد عليها، وسأستلم نسخة من هذا النموذج.

التاريخ: اسم المشاركة:

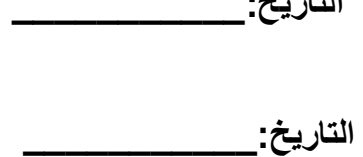
توقيع المشاركة: توقيع الثخص الذي سيحصل على هذه الموافقة: 


\section{Appendix 4.}

IRB-Florida International University

\section{FIUI UNIVERSITY}

Office of Research Integrity Research Compliance, MARC 414

Dr. Catherine Coccia

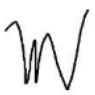

"A mobile-based intervention for obesity prevention among female college students in Saudi Arabia: A randomized controlled trial"

The Institutional Review Board of Florida International University has your study for the use of human subjects via the process. Your study was found to be in compliance with this institution's Federal Wide Assurance (00000060).

IRB-17-0359

105842
$11 / 06 / 17$

IRB Expiration Date: $11 / 06 / 18$

As a requirement of IRB Approval you are required to:

Submit an IRB Amendment Form for all proposed

Receive annual review and re-approval of your study prior to your IRB expiration date. Submit the IRB Renewal Form at least 30 days in advance of the study's expiration date. or discontinued.

Special Conditions: $\quad$ N/A.

For further information, you may visit the IRB website at http://research.fiu.edu/irb MMV/em 
Appendix 5.

IRB-Princess Nourah bint Abdulrahman University "English"

\author{
Kingdom of Saudi Arabia \\ Ministry of Education \\ Princess Nourah Bint Abdufrahman University \\ (048) \\ Institutional Review Board
}
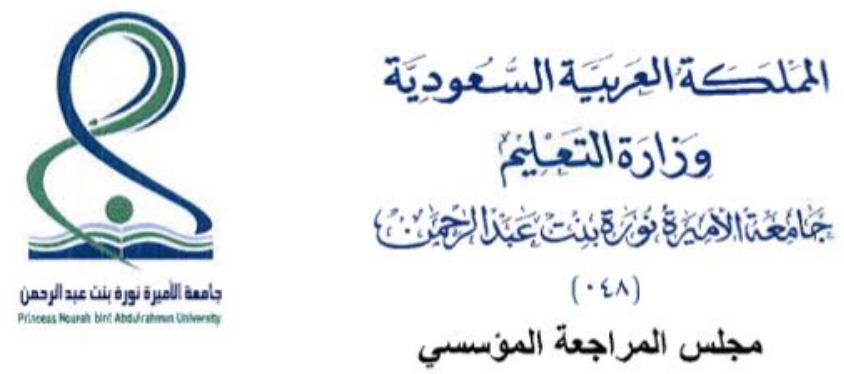

Date: 10/17/2017

Reference Number: 17-0120

Name of the study: A mobile-based intervention for obesity prevention among female

college students in Saudi Arabia: A randomized controlled trial

Type of IRB: Exempt

Dear researcher: Abeer Hussain Alssafi

Thank you for submitting your proposal to Princess Nourah bint Abdulrahman University (PNU) Institutional Review Board.

We would like to inform you that after reviewing your proposal and making sure that there is no known risks associated with the study procedures, provide you an exempt IRB. However, you still have to provide us the external IRB.

If there are further changes regarding the procedures, please inform PNU-IRB before start applying it. You will have to fill out an adjustment form when the changes happen.

Please inform the PNU-IRB if the study stops anytime during the study. Moreover, kindly inform the PNUIRB if the study risks outweigh the benefits. If that happens, the PNU-IRB will ask you to provide details information and how will you deal with it.

Please provide PNU-IRB a report every 6 months. Additionally, please indicate the number above in every message related to the study. Please provide us with any manuscript before publishing it.

We wish you best of luck.

Please contact us for any further information

Regards,

Dr. Ibtesam Almadhi

Head of the IRB Department

Princess Nourah bint Abdulrahman University

Phone: +966 8240861

Email: $\underline{\text { rb@ @pnu.edu.sa }}$ 


\section{Appendix 5.}

\section{IRB-Princess Nourah bint Abdulrahman University "Arabic"}

\section{Kingdom of Saudi Arabia Ministry of Education}

Princess $\mathcal{N}$ ourah Bint A6dufrahman thiversity (048)

\section{Institutional Review Board}

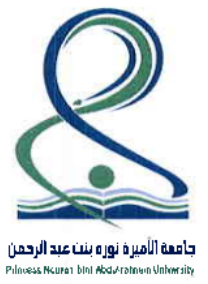

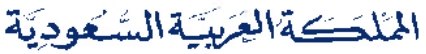

$$
\begin{aligned}
& \text { وكارة التتعبلئحج }
\end{aligned}
$$

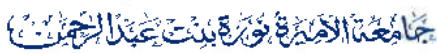

$$
\begin{aligned}
& (\cdot \leq 1) \\
& \text { مجلس الممراجعة المؤسسسي }
\end{aligned}
$$

رقم تسجيل المجلس لدى مدينة الملك عبدالعزيز للعلوم و التقنية 059-H-01-IR

$$
\text { التاربخ : 17-10-2017م }
$$

رقم المعاملة : 17-0120 - مق

اسم البحث: ( استخدام الهاتف المخمول لمنع السمنة لدى طالبات الجامعات في السعودية عن طريق استخدام

وسائل التوإصل الاجتماعيه)

تصنيف الموافقة : مغفي

سعادة الباحثة عبير بنت حسن الصافي

نشكر للك تقديمكم خطتكم البحثية لمجلس المراجعة المؤسسي فيـ جامعة الأميرة نورة بنت عبد الرحمن.

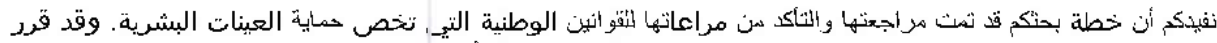

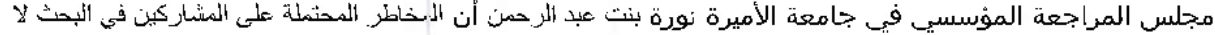

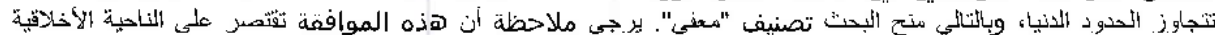

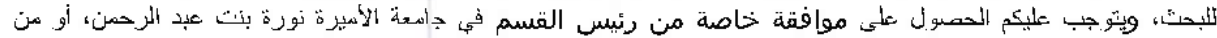
الجهات المعنية في أية مؤسسة خارجية ثبل البدء بجميع البيانات.

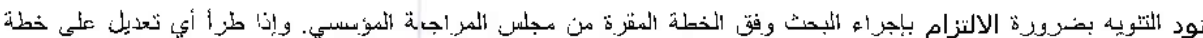

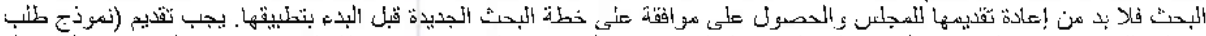

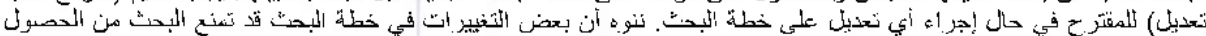

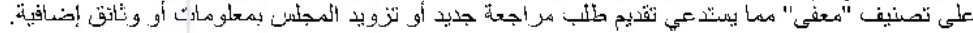

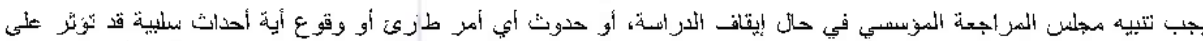

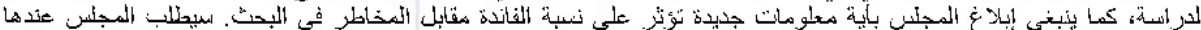

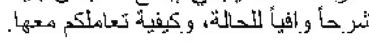

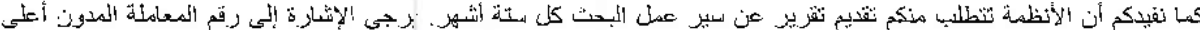

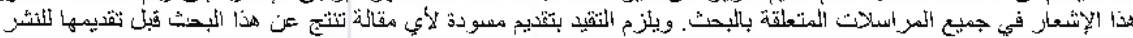

تتمنى الك التوفيق. ونرجو التُو إصنل معنا إذا كان لديكم أي استفسار.

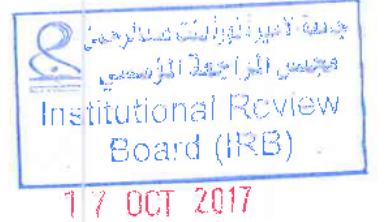

مع أطيب تحية وتقدير،

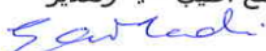
د. ابتسام الماضيـ رتيس مجلس المراجعة المؤسسى المعيى جامعة الأميرة نورة بنت عبداليدة الروحن رقم الهاتف: 8240861 966 بون البريد الالكترونيـ: irb@pnu.edu.sa 
Appendix 6.

\section{Fitbit}

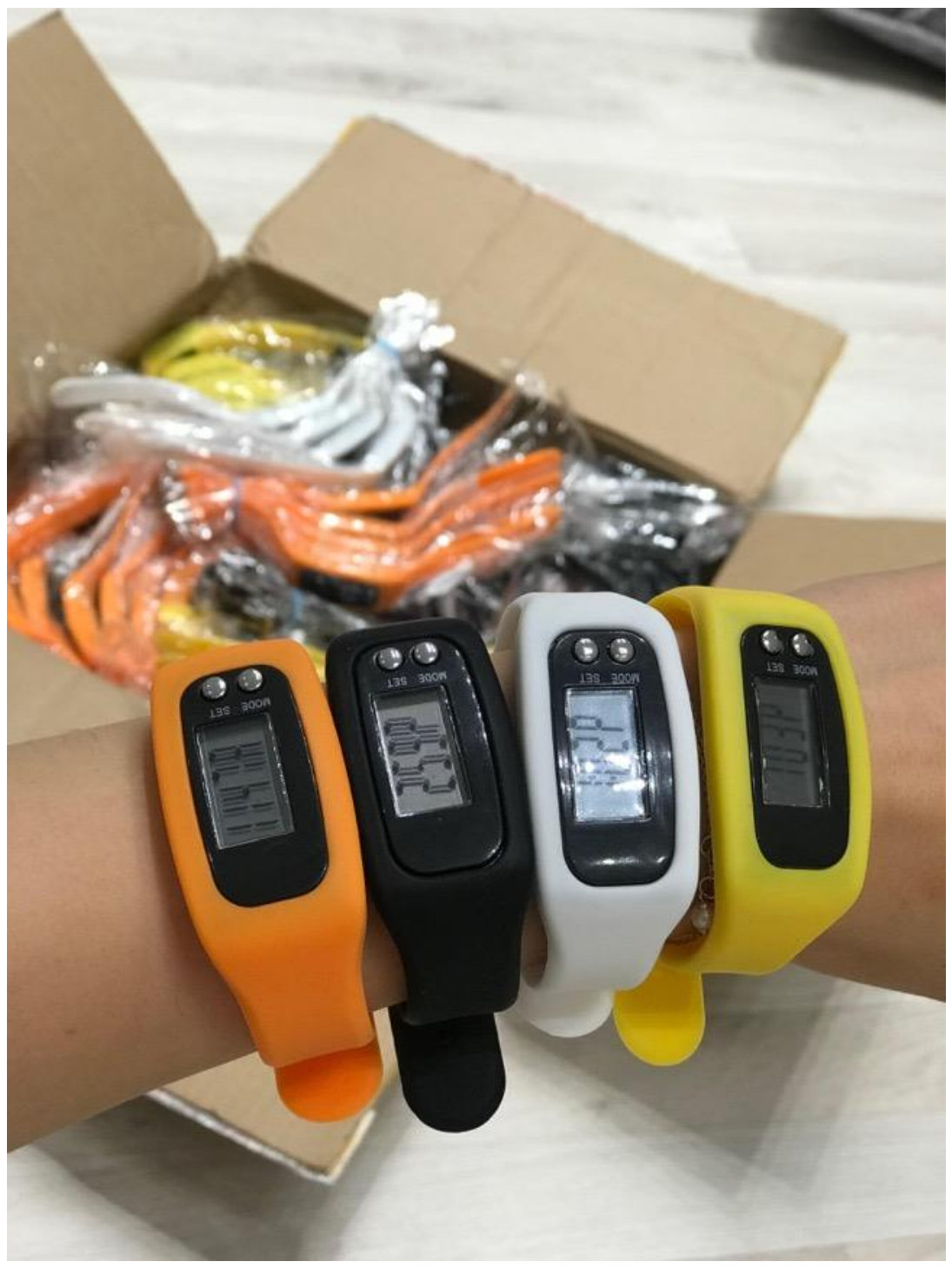


Appendix 7.

Logo "English"

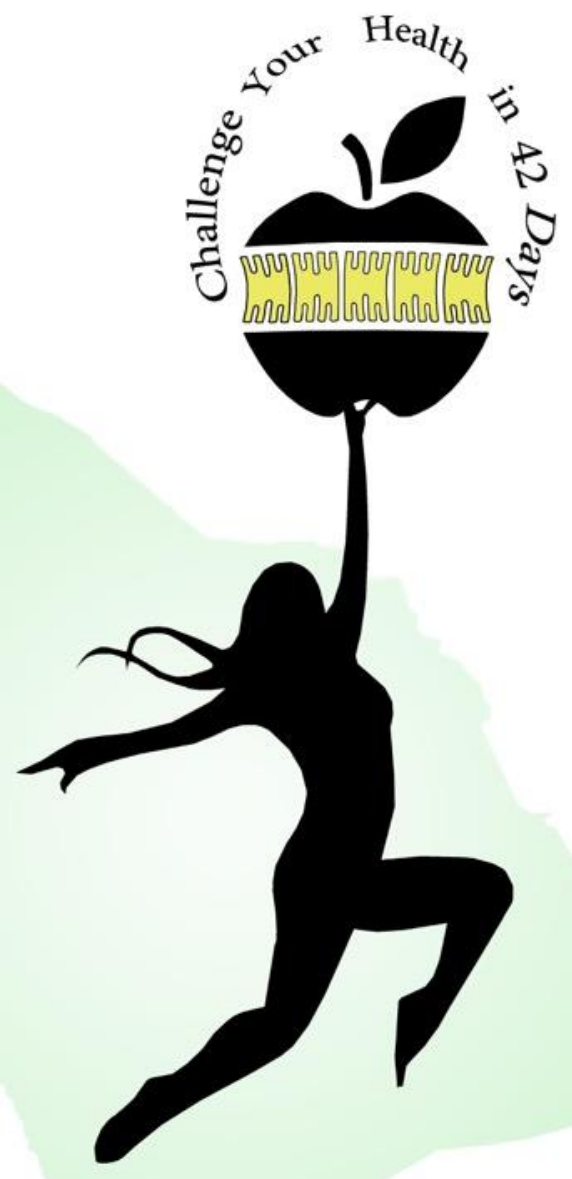


Appendix 8 .

Logo "Arabic"

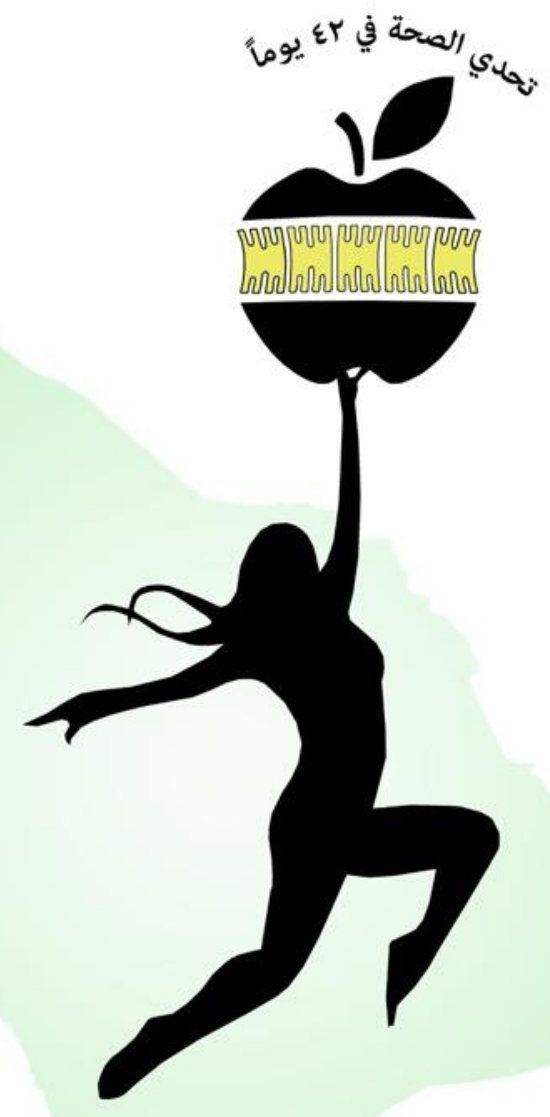


Appendix 9.

Instagram Topics

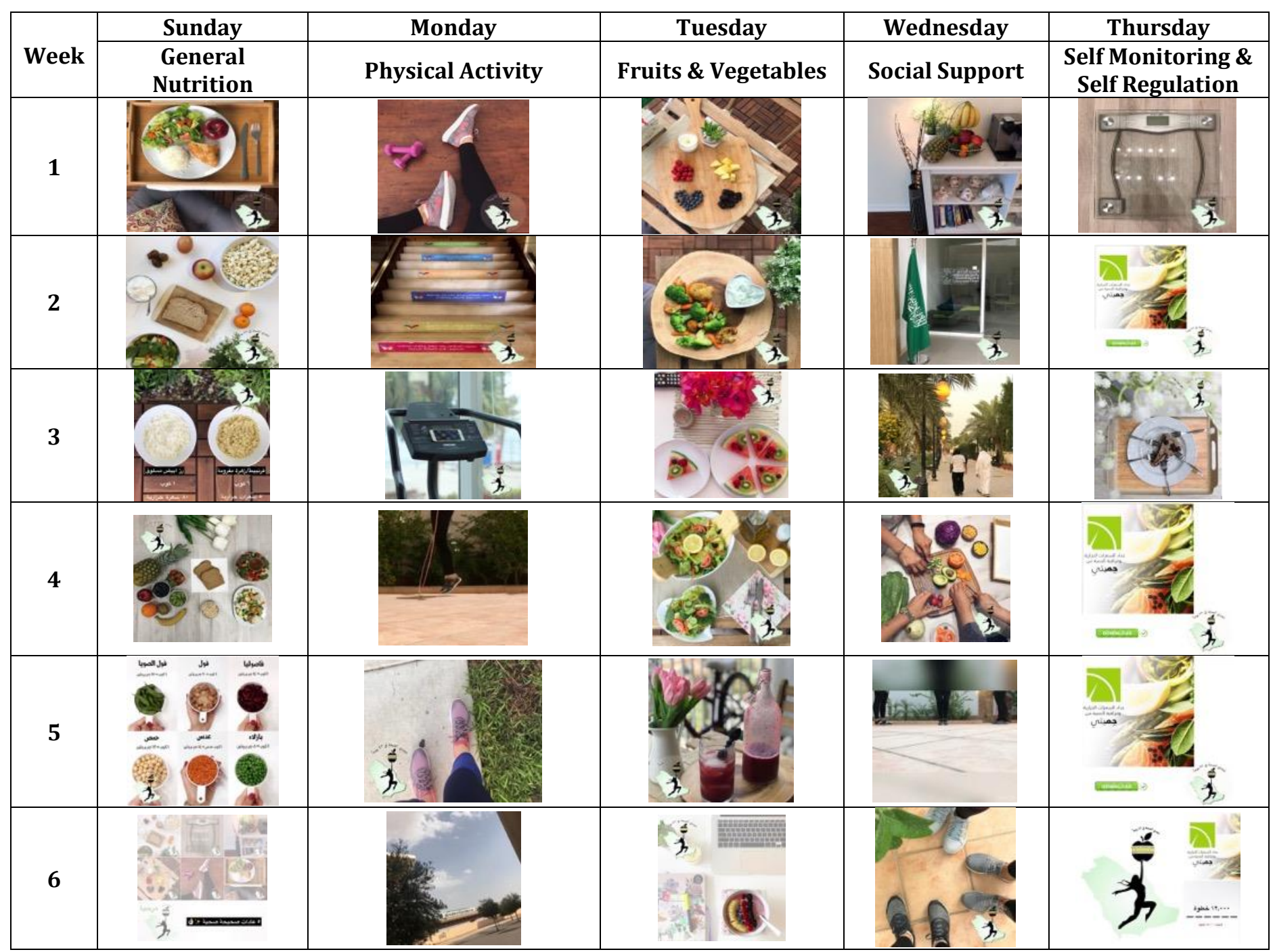




\section{Topic 1 "General Nutrition"}

\section{Week 1 (MyPlate):}

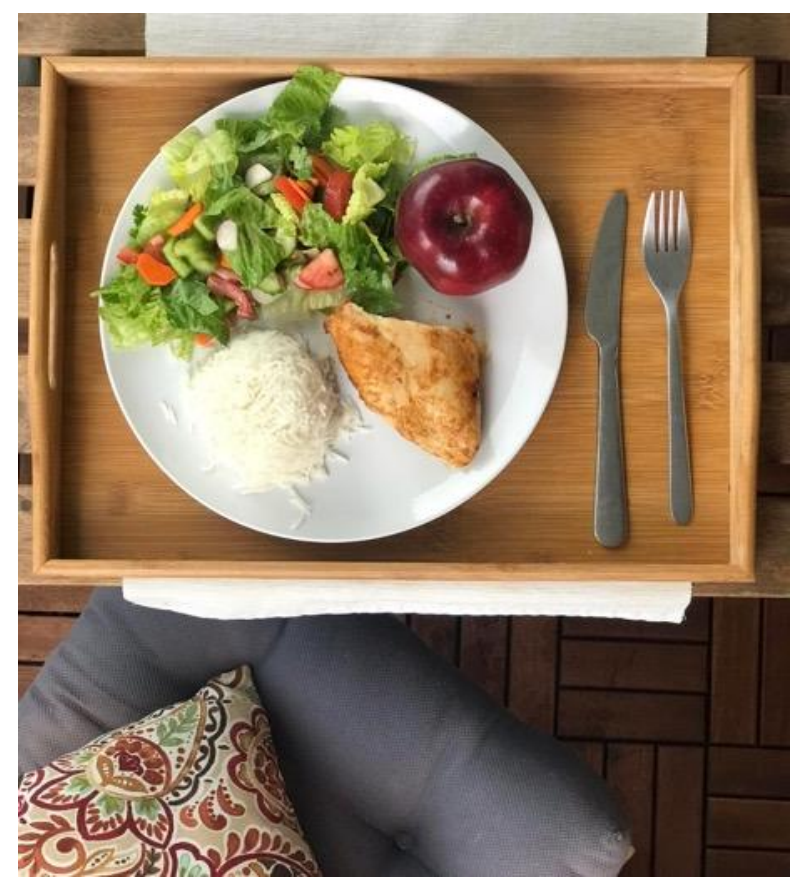

$$
\text { كيف يكون صحني [صحن صحي] }
$$

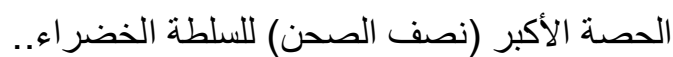

*مكن استبدالها بالخضار المطبوخة او الايدامات كالملوخية والرجلة والسرة السبانخ وغيرها..

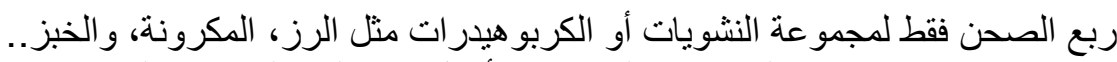

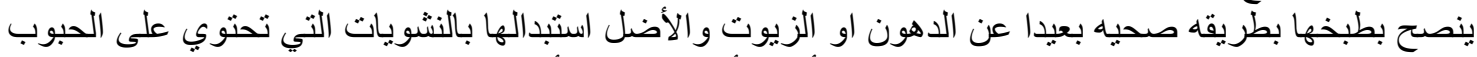

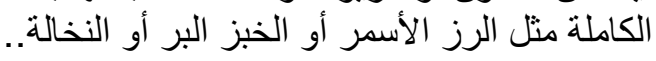

الربع الأخير من الصحن يجب أن يحتوي على مجموعة البروتينات مثل الدجاج واللحوم و الأسماك و الأجبان قلبلة الدسم و البيض. البرونات

*ينصح بطبخ اللحوم والدجاج و الأسماك بطريق صحية كالثوي أو السلق.

حتى تكون وجبني صحيه تماما ينصح بتناول حبه من الفاكهة أو نصف كوب من لطة الفو اكه مع الجبة أو أكلها كجبة خفيفة بعد الوجبة الرئيسيّة.

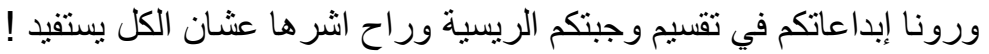

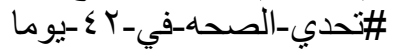

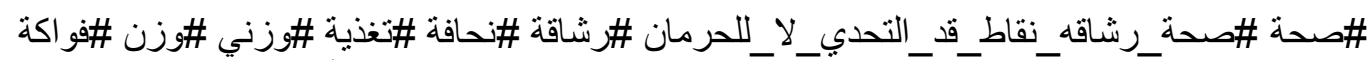

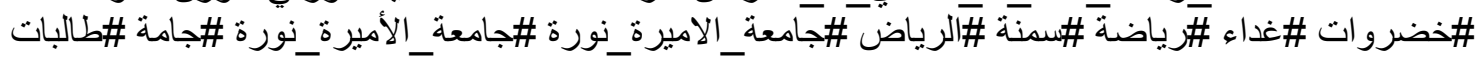

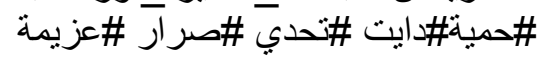


Week 2

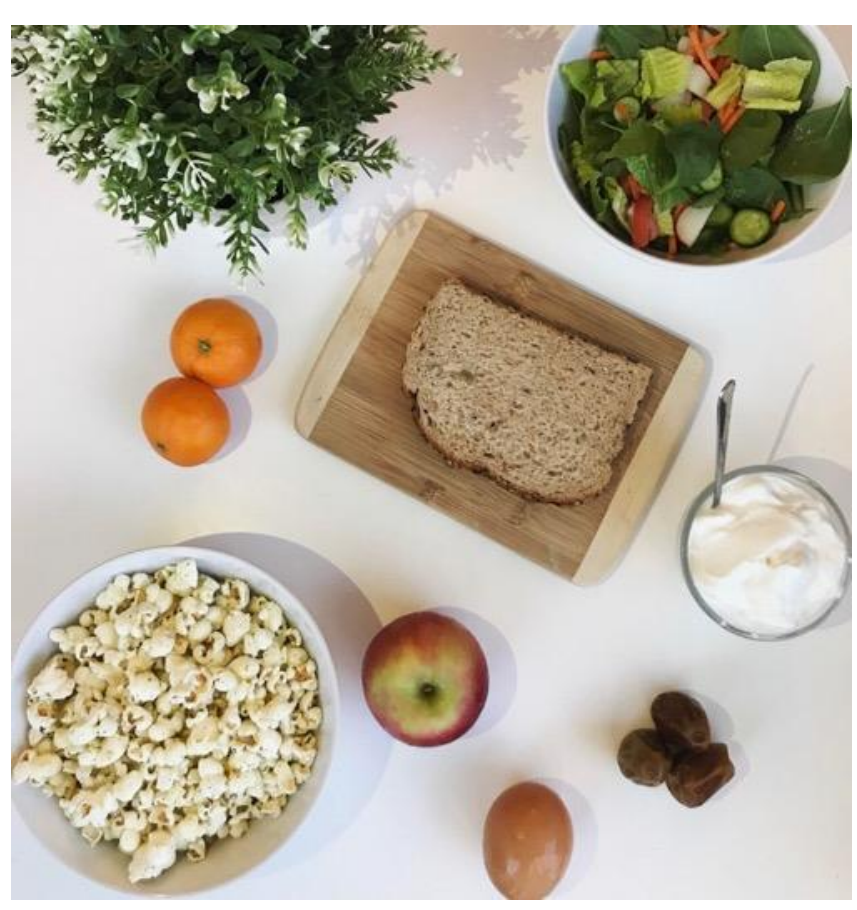

(Snack):

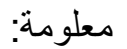

تعرفون ان الوجبة الخفيفة/سنالك المفروض تحتوي على أقل من • 10 سعرة حرارية؟

6

في الصورة أمثلة لبعض الوجبات الخفيفة اللي ممكن تتناولو ها خلال اليوم!

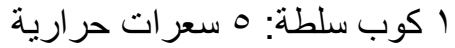

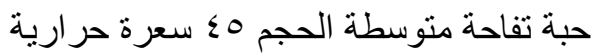

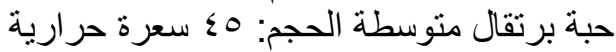

r حبات تمر: هب سعرة حرارية

بيضة واحدة: 70 سعرة حر ارية

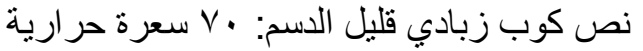

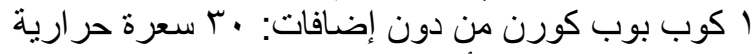

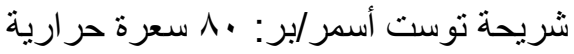

عندكم إضافات ثانية لوجبات خفيفه صحيه؟

\#تاركوناوجباتكم الخفيفة على هذا الهانتاق

\#تحي-الصحه-في_ץ ؟-يوما 


\section{Week 3 (White Rice VS Cauliflower Rice):}

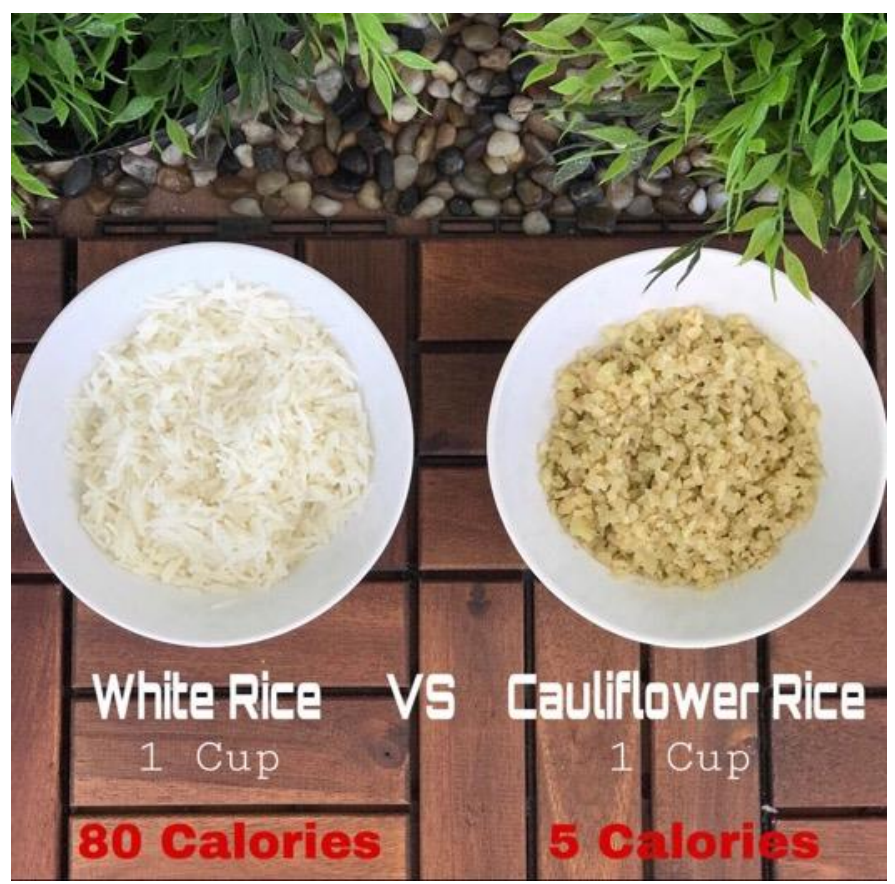

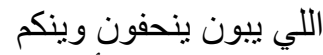

$$
\begin{aligned}
& \text { اللي سمعت عن رز الزهرة المفرومة أو جربته من قبل ترفع يدها }
\end{aligned}
$$

رز الزهرة عبارة عن زهرة مفرومة تقدروا تاكلوا منها الكمية اللي تبغو ها لأنها تعتبر من مجمو عة \#الخضروات

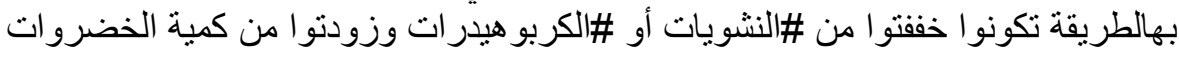

$$
\text { طريقة اعدادها: }
$$

ا ـ قطعي الزهرة قطع صغيرة ثم غسليها جيدا:

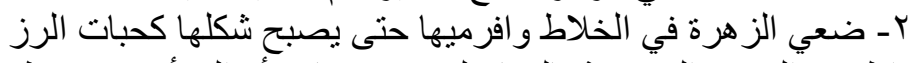

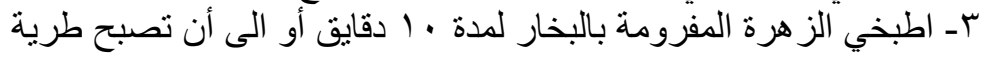

أكيد طعهها مو زي طعم الرز بس اللي حابة تنزل من وزنها هالطريقة بتساعدها كثير في نزول الوزن

$$
\begin{aligned}
& \text { جربو ها وشاركونا التجربه }
\end{aligned}
$$

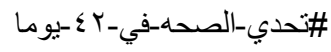

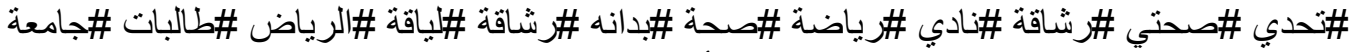

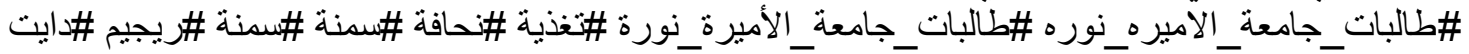

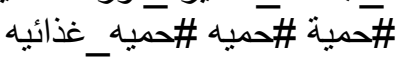




\section{Week 4 (Fiber):}

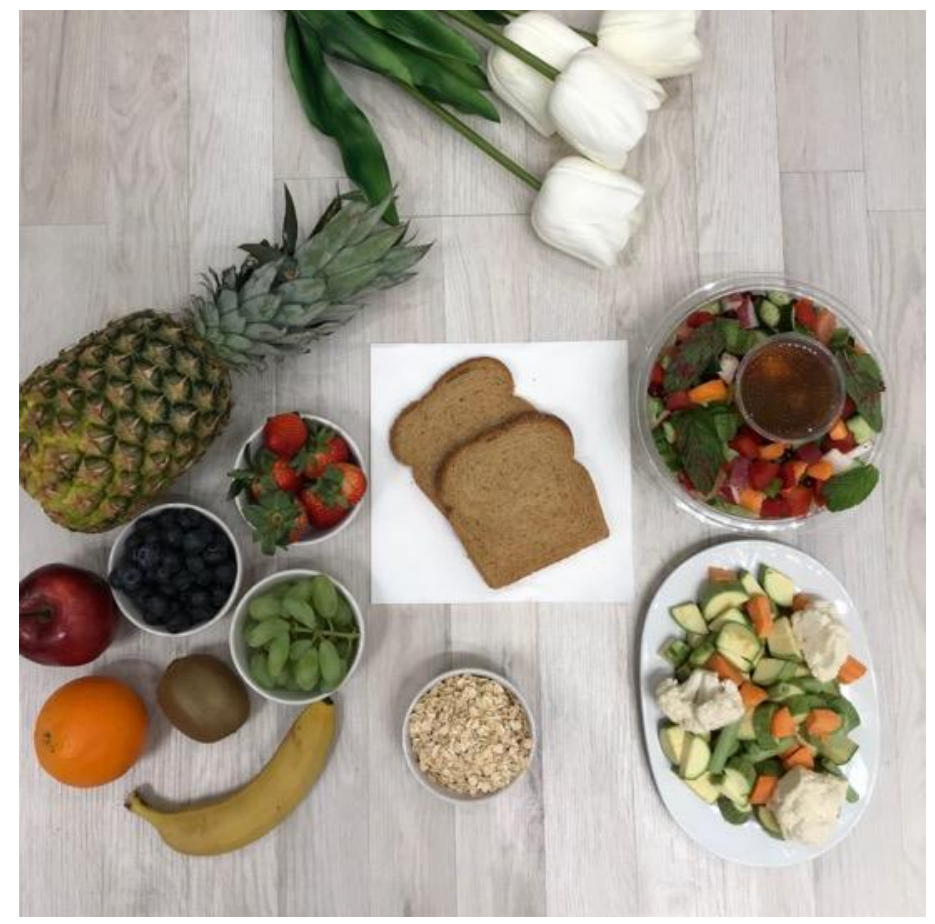

$$
\text { تحدي هالأسبوع..! }
$$

أكيد كلكم سمعتو ا عن الألياف الغذائية! بختبر معلوماتكم ! اللي تعطيني جواب كافي للأسئلة اللي بطرحها بتفوز

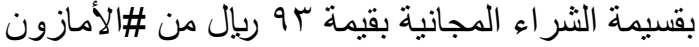

$$
\begin{aligned}
& \text { ماهي الألياف الغذائية؟ } \\
& \text { وماهو دور هاب؟ } \\
& \text { وماهي مصادر ها؟ } \\
& \text { وكم نحتاج يوميا؟ } \\
& \text { ن }
\end{aligned}
$$

\في الصوره بعض من مصادر الألياف الغذائية ـ غششتكم بواحد من الأسئلة

$$
\text { اكتبوا أجوبتكم في اضافة "تعليق" واللي تعطيني الجو اب الكافي لها الجائزة }
$$

\section{6 \\ 6}

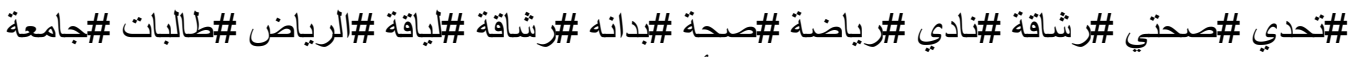
\#البات_جامعة_الاميره_نوره \#طالبات_جامعة_الأمبرة_نورة \#تخذية \#تحافة \#سمنة \#سمنة \#ريجيم \#دايت \#مية \#حميه \#حميه_غذائبه 


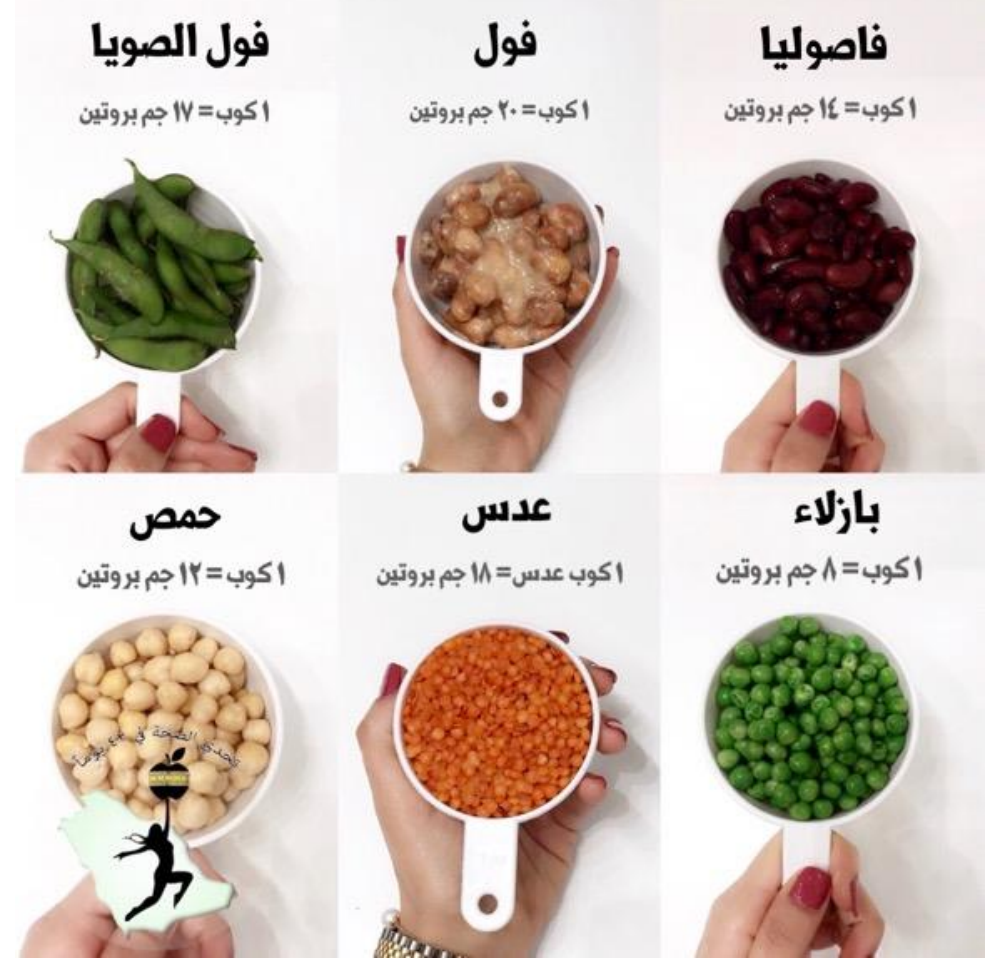

مصادر البروتين النباتية

لأن في طرق عديدة لزياده البروتين في غذاننا حبيت اثـارككم ببعض الأطعمة اللي ممكن تزيدونها في يومكم عشان

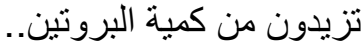

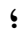

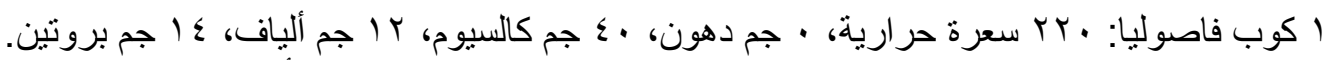

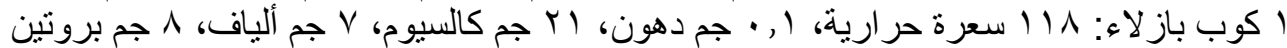

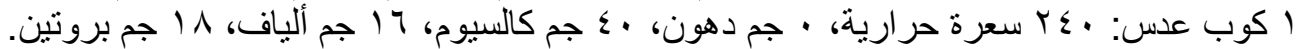

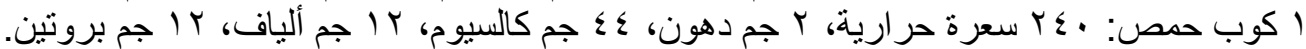

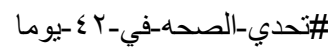


Week 6

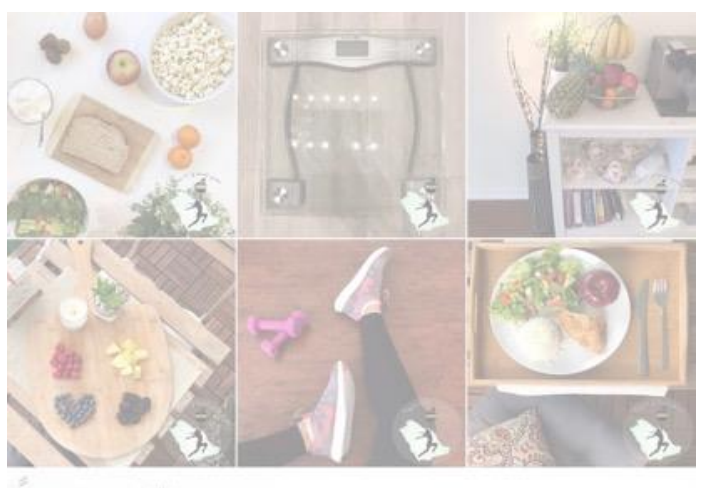

\section{(Challenge):}

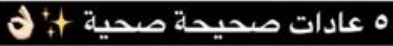

$$
\text { اذا انتبهتو كان كل يوم في الأسبوع مخصنا الاسبوع الموضير و التحدي الأخير معين (0 مو اضيع من الأحد الى الخميس). }
$$

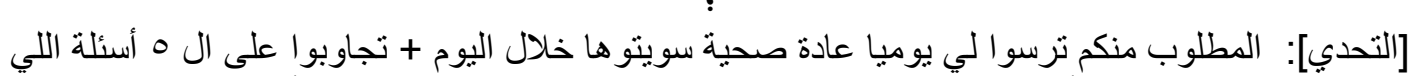

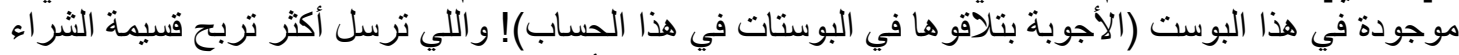
المجانية بقيمة بو البوسنات في من الأمازون

في الفديو/البوست بتشوفون بعض العادات الصحية والصحيحة اللي تكلمنا عنها في الأسابيع الماضية برجع أذكركم

$$
\text { ببعض منها: }
$$

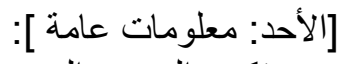

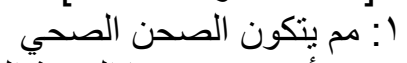

r: كم سعرة حرارية يجب أن لاتزيد عنها الوجبة الخفيفة مع ذكر مثال الرئ

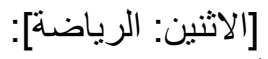

r و ؟: كم سعرة حر ارية نحرق في صعود الدرجن الريأن ورياضة نط الحبل

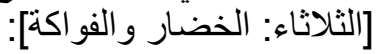

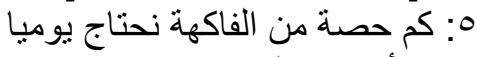

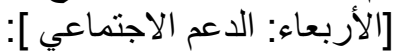

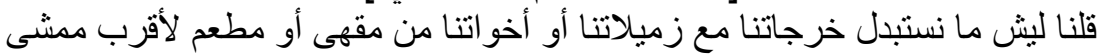

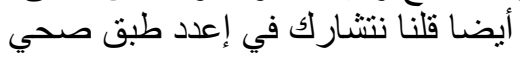

$$
\text { [الخميس: مر اقبة النفس]: }
$$

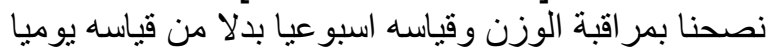

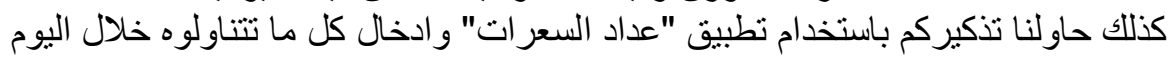


أجوبتكم في التعليقات في الاسفل عندكم ليوم الخميس تجاوبوا على الأجوبة + ترسلو اللي العادات الصحية اللي سويتو ها خلال الأسبوع

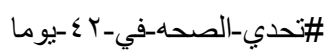

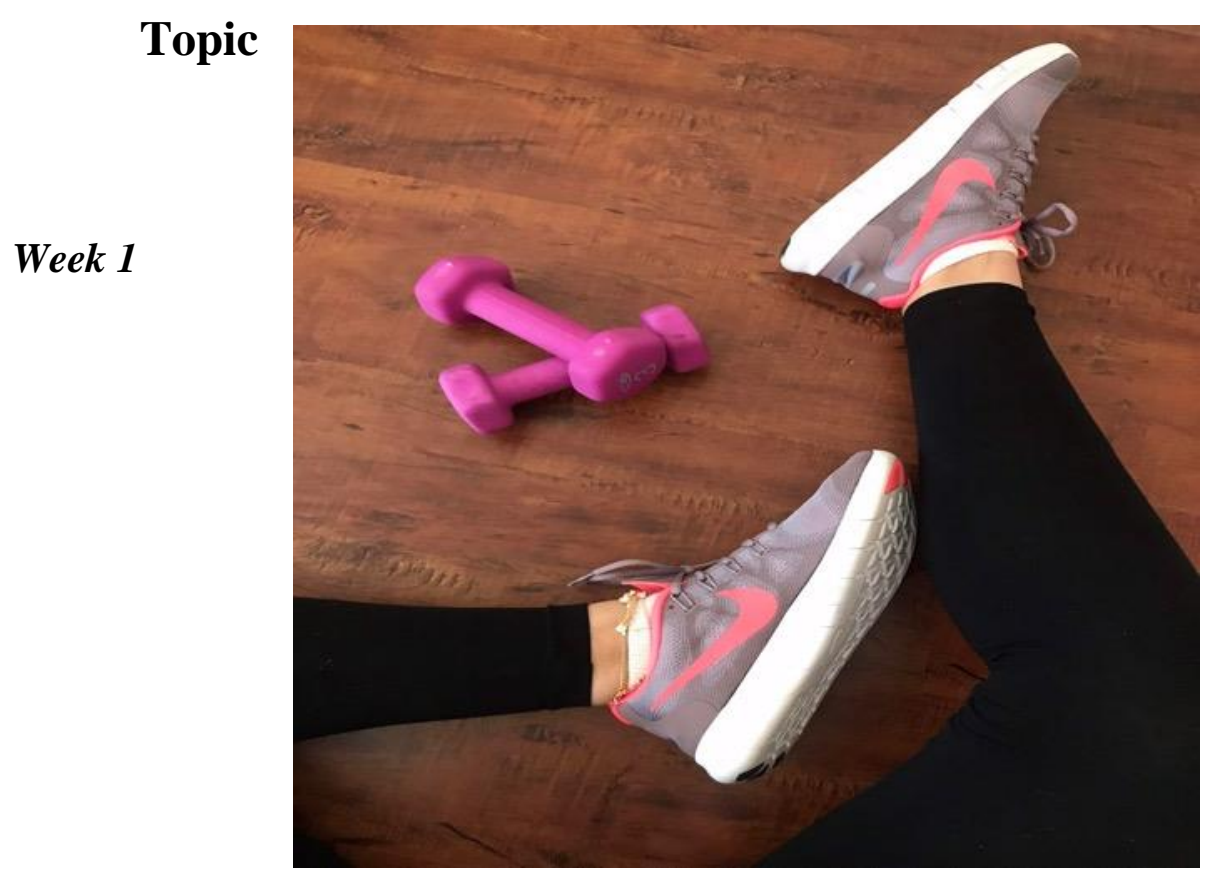

2 "Physical

Activity"

(Motivation):

مالكم خلق تسوون رياضة أو ماعندكم وقت تسوون فيه أي نشاط رياضي؟!

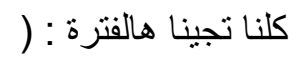

أحسن حل ممكن يشجعنا نسوي رياضة اذا ماكان لنا خلق هو اننا نشنري جزمة : هالفر رياضة أو او ملابس رياضة جديدة

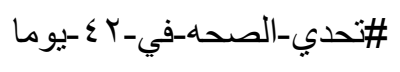

مين تبدأ أول وحدة وتشاركنا التجربة 


$$
\text { ان كنت جربيتها قبل شاركينا التجربة }
$$

\#حه \#تحدي \#تغذية \#نحافة\#\#شاقة \#سمنة \#بدانة \#الرياض \#جامعة_الأميرة_نورة \#طالبات \#بنات \#دايت \#ميه \# 
Week 2 (Stairs):

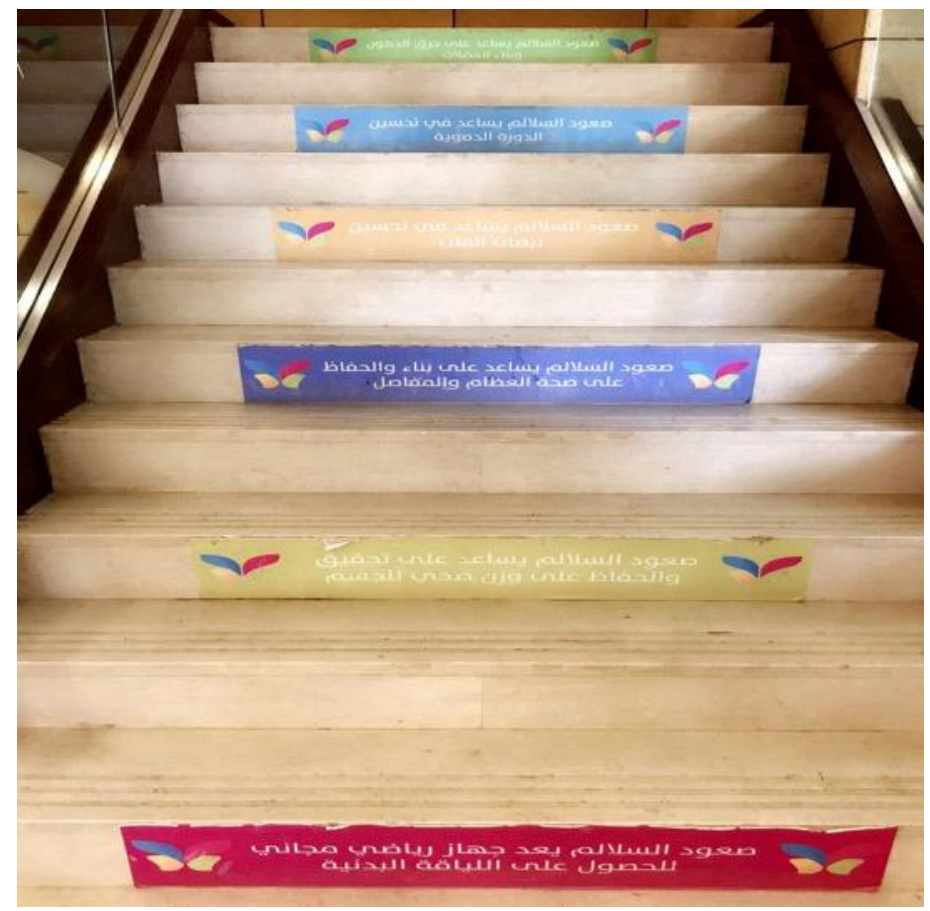

مين تحرص على صعود الدرج بدل من استخدام المصعد أو السلم الكهربائي؟

عندكم علم بأن صعود الدرج لمدة 10 دقيقة يمكنك حرق تقريبا • ــ ا سعرة حر ارية وهي السعرات نفسها الموجودة

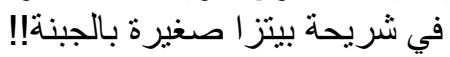

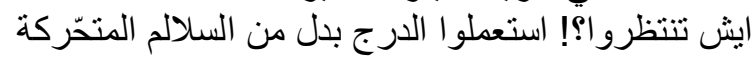

خلونا نحرق سعرات بدل ما نحرق كهرباء.ا.

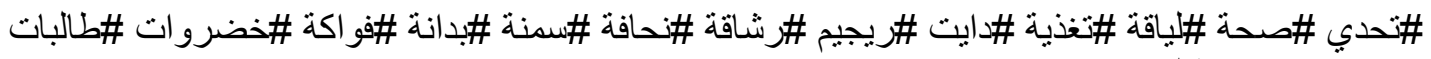

\#طالبات_جامعة_الاميرة_نورة \#سعر ات \#سعر ات_حر ارية \#سعر ات_حر اريه 


\section{Week 3 (Statistics):}

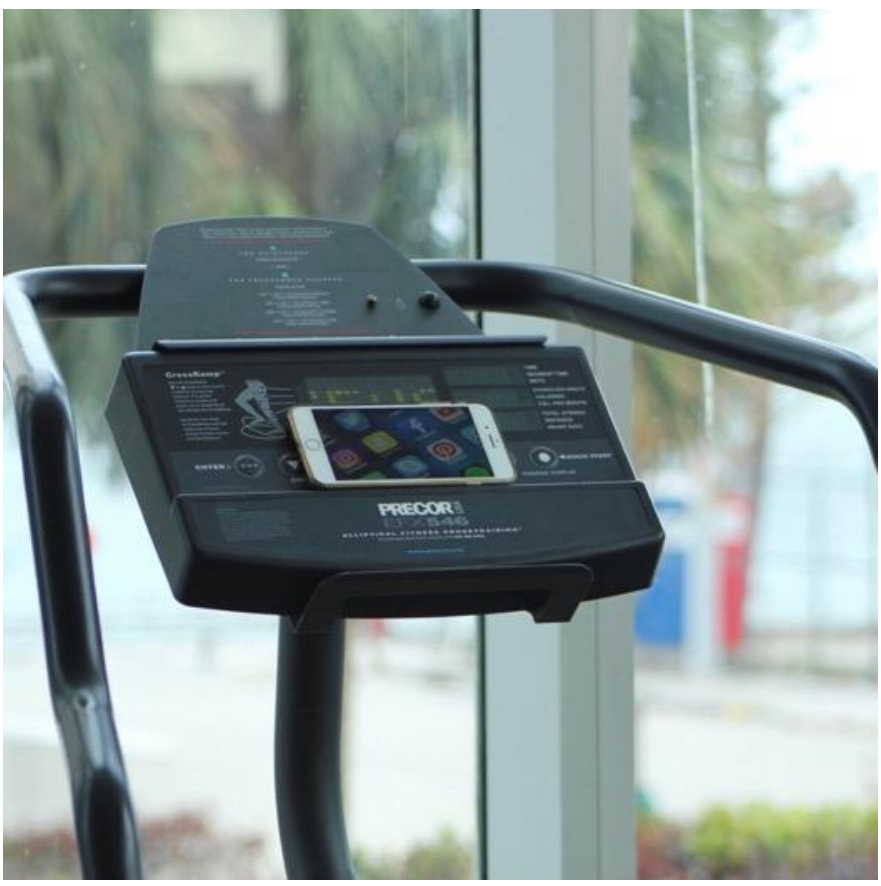

كم ساعة في اليوم تقريبا تقضو ها على وسائل التو اصل الاجتماعي ؟ أنا تقريبا ؛ ساعات \#وانتو ا

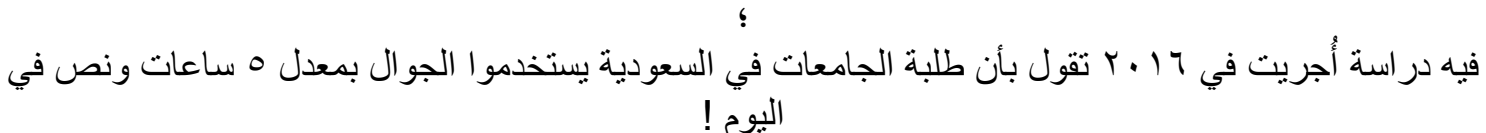

$$
\text { كلكم تعرفوا كيف الجلسة هذي ممكن تؤثر على الوزن !! ؛ }
$$

فكرة:

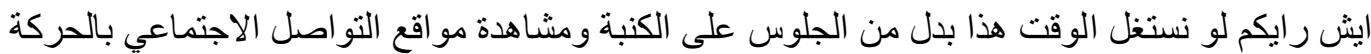

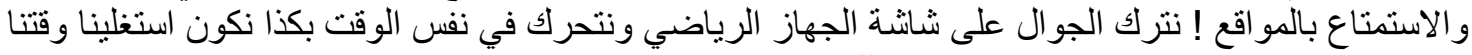
اللي كان ضايع ضايع

$$
\text { تحدي-الصحه-في-ب گ-يوما }
$$

تحدي \#صحتي \#رشاقة \#نادي \#زياضة \#صحة \#بدانه \#رشاقة \#لياقة \#الرياض \#طالبات \#جامعة

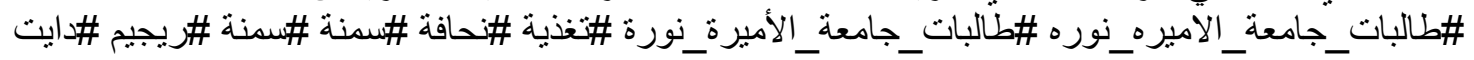
\#حمية \#حميه \#حميه_غذائيه 


\section{Week 4 (Jump Rope):}

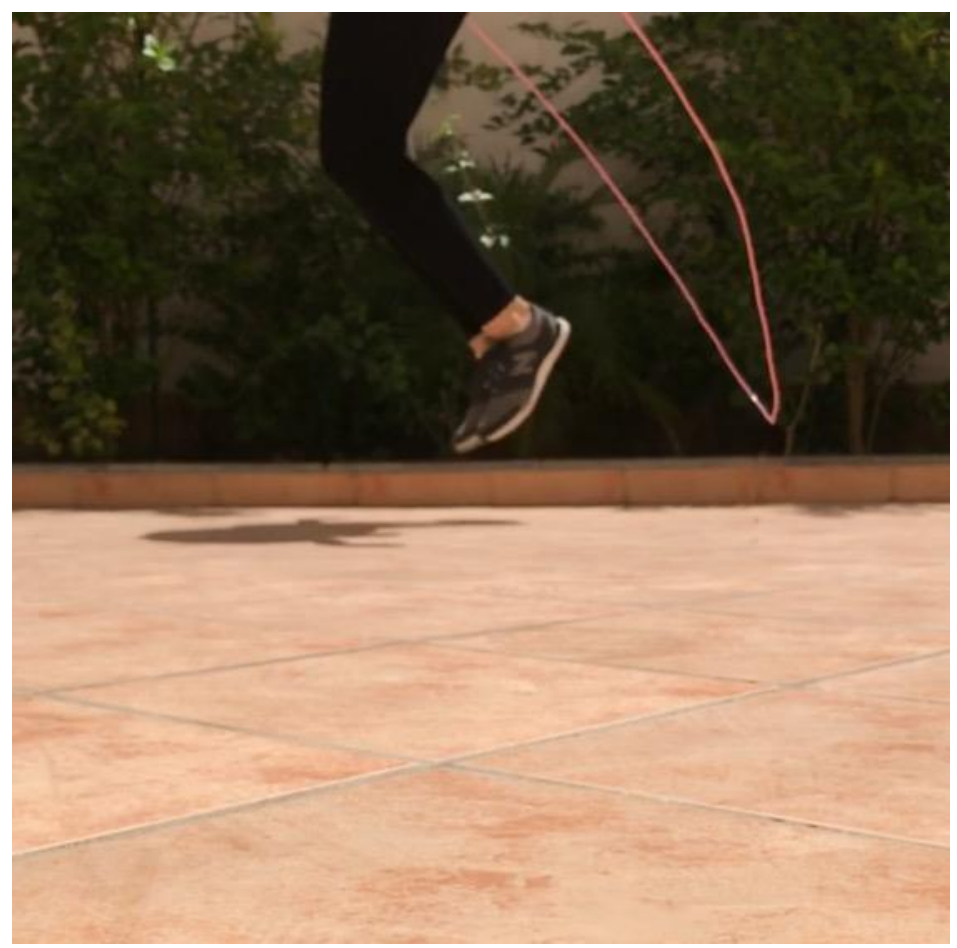

مين تمارس رياضه الحبل ترفع يدها؟

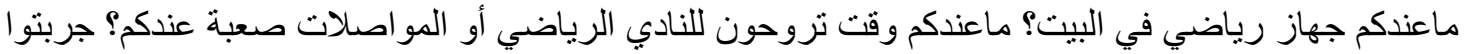

تشترون الحبل الرياضي وتستخدمونه في البيت؟ الحبل قيمته تقريبا 10 ربإل لكن نتائجه سريعة وحلوة!

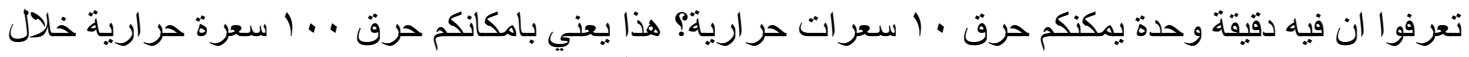

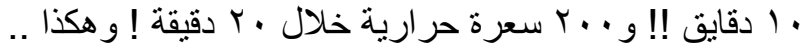

هذي وحده من الرياضات السريعة الحرق و اللي عن طريقها تقدروا توصلو ا للشكل المطلوب ! جربوها تحدي-الصحه-في-بع -يوما

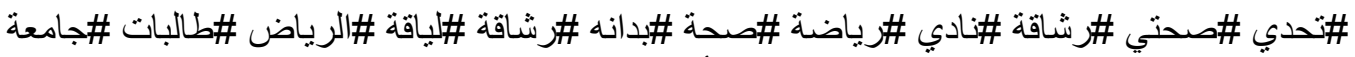
\#البات_جامعة_الاميره_نوره \#طالبات_جامعة_الأميرة_نورة \#تخذية \#تحافة \#سمنة \#سمنة \#ريجيم \#دايت

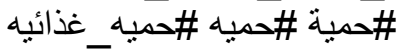




\section{Week 5 (Walk):}

\section{Xxxx}

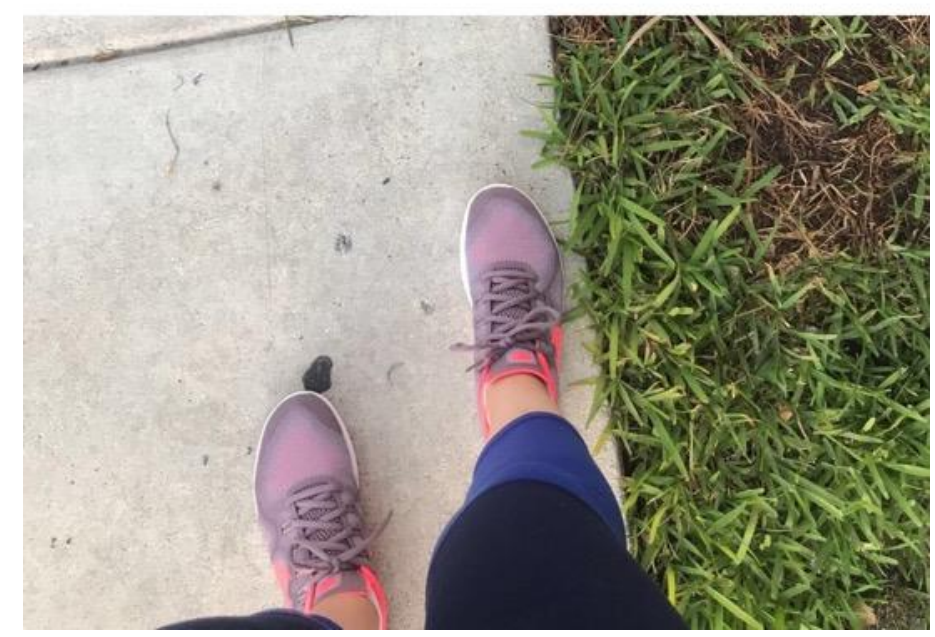

$$
\text { تحدي هالأسبوع }
$$

لمين قسيمة الثر اء المجانية بقيمة به ريال من الأمازون هالمرة؟ !

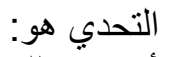

بنشوف عدد الخطوات كاملة خلال الأسبوع! اللي تجيب أكبر رقم خطوات لهات الها الجائزة

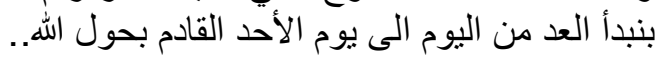

$$
\text { المطلوب منكم ترسلوا لي عدد الخطوات اللي يسجلها التطبيق في نهاية كل يوم.. }
$$$$
\text { تحدي-الصحه-في-rك -يوما }
$$

6

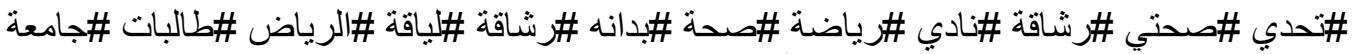
\#طالبات_جامعة_الأميره_نوره \#طالبات_جامعة_الأميرة_نورة \#تغذية \#تحافة \#سمنة \#سمنة \#ريجيم \#دايت \#مية \#مميه \# 


\section{Week 6 (Walking instead of using the metro):}

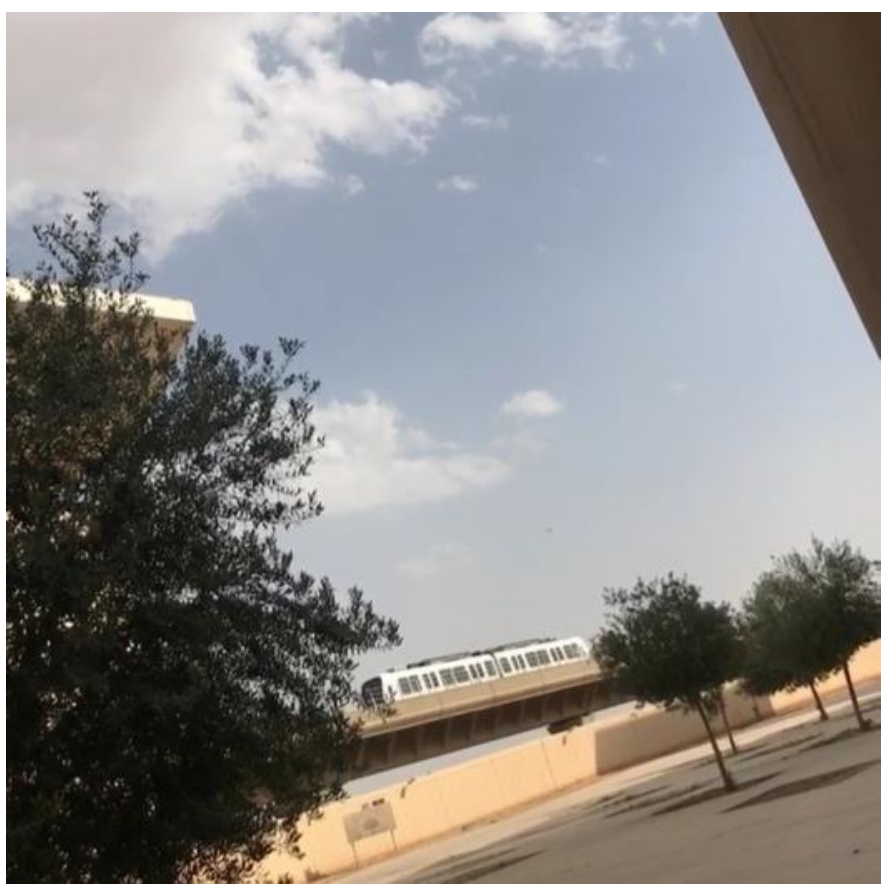

مين تفضل انها تمشي بدلا من استخدام المترو؟ ترفع يدها

أخر مره زرتكم قلت بجرب أشوف كم خطوة أحرق "بالمشي" من محطة لمحطة !

أحد عنده علم كم دقيقة مشي من محطة لمطة؟ وكم خطوة تقريبا ؟!

اللي محافظين على الرياضة و اللي تستخدمو ا تطبيقات عداد الخطوات جاوبو ا ..

أنا أنحسبت عندي في التطبيق • خطوات في أقل من دقيقة ..

هذى يعني بأن في أقل من ه دقائق نكون وصلنا للمحطة الخامسة !

لسا بتاخذوا المترو؟ و لا بتشجعين زميلاتك إنكم تتنقلو امشي بين المحطات؟

$$
\text { تحدي-الصحه-في_r گ -يوما }
$$




\section{Topic 3 "Fruits \& Vegetables"}

\section{Week 1 (Fruit / serving size):}
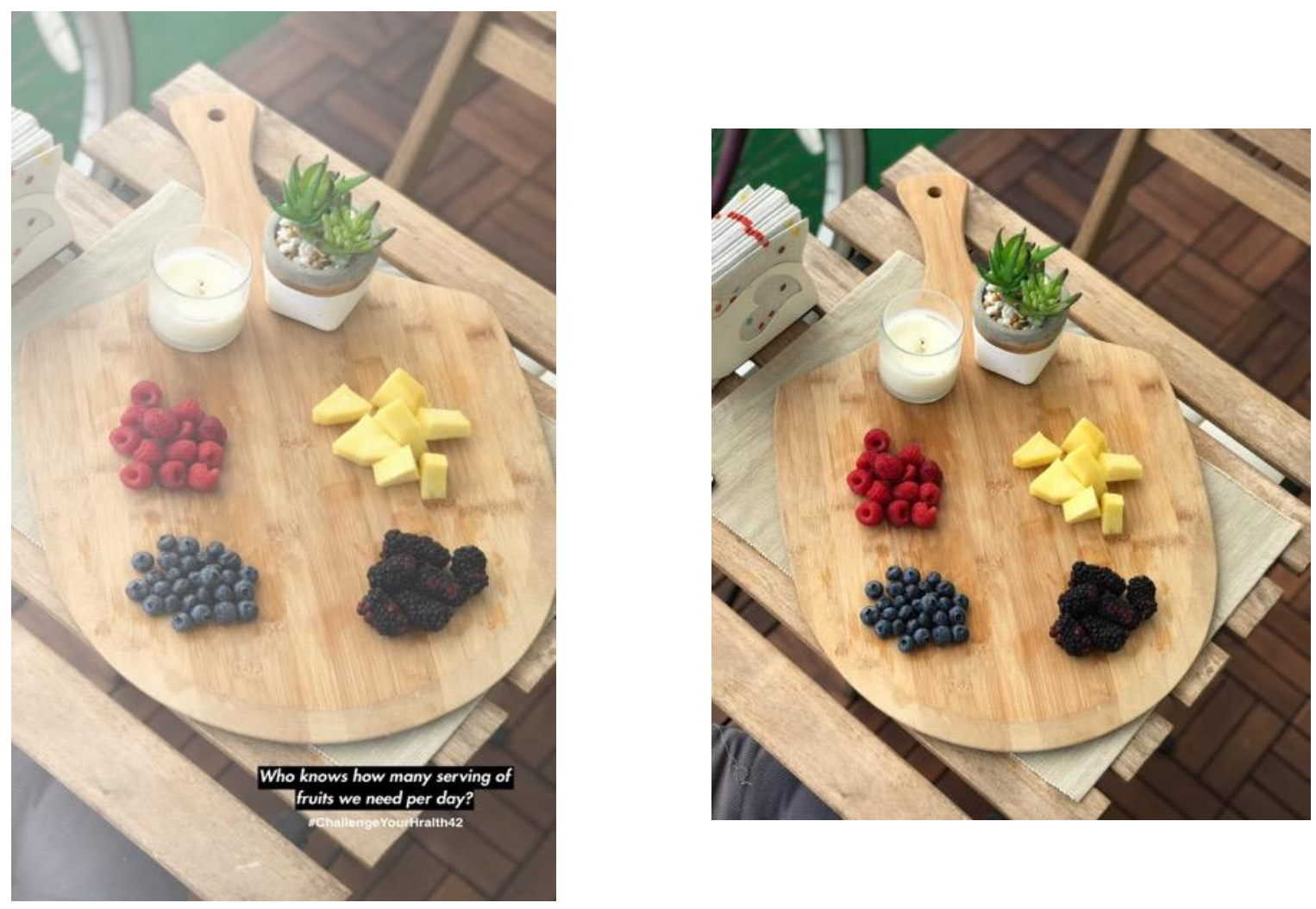

$$
\begin{aligned}
& \text { جواب السؤال اللي سألته اليوم.. }
\end{aligned}
$$

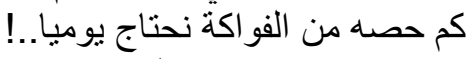

$$
\begin{aligned}
& \text { نحتاج ب-؛ حصص من الفواكة الفواجة بوميا. }
\end{aligned}
$$

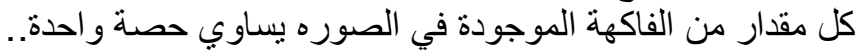

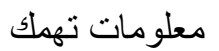

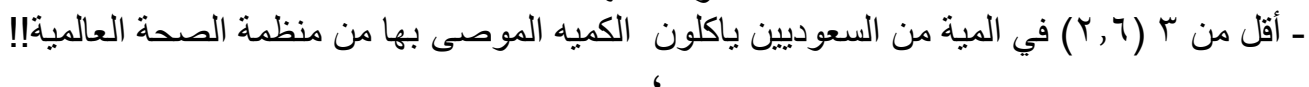

ـ قله أكل الخضروات و الفو اكة تزيد من نسبة الإصـابة بالأمر اض المزمنة كأمر اض القب و السكري و السمنة.. اذا قريتي المعلومة وتذكرتي انك لم تتناولي ولا حصة من الفواكة،، احرصي على تناول حصتين على الأقل قبل

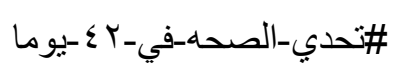

\#ححّة \#تحدي \# تغذية \# نحافة \#رشاقة \#سمنة \#بدانة \#الرياض \#جامعة_الأميرة_نورة \#طالبات \#بنات \#دايت \# \#مية 
Week 2 (Cooked Vegetables):

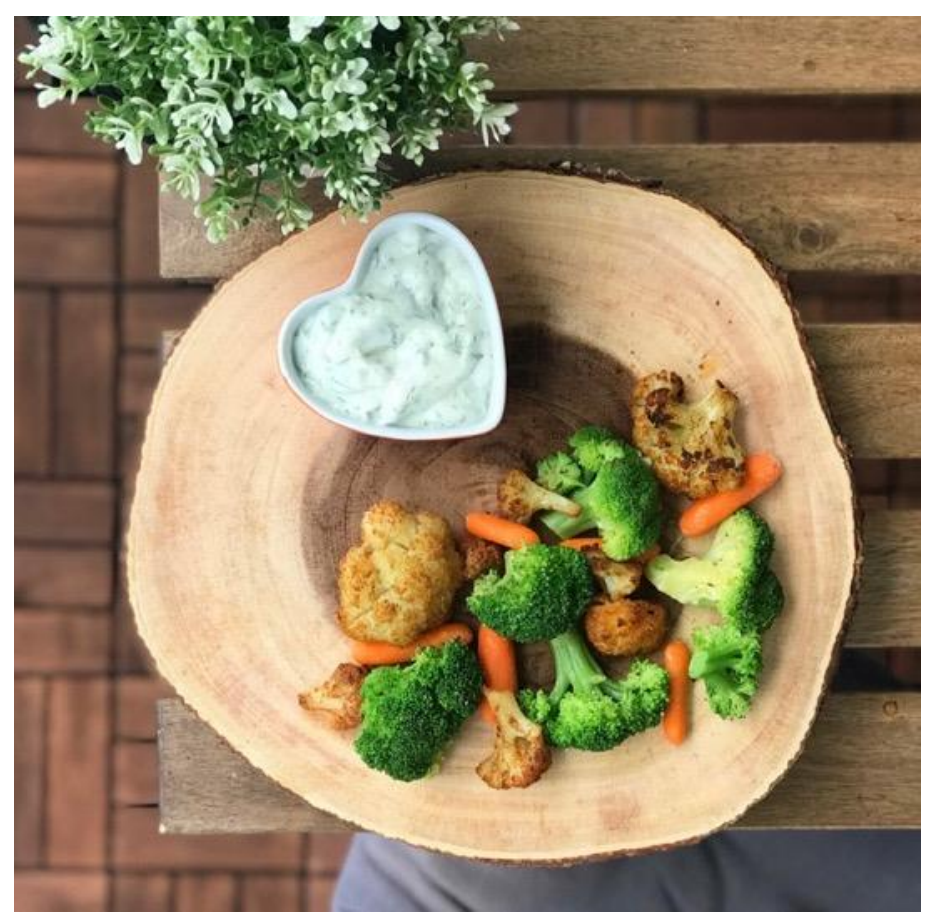

ايش تتاولتوا اليوم من مجمو عة الخضروات؟

\#سلطة_خضر اء ؟ ولا \#خضار_مطبوخة ؟ و ولا ايدامات زي الملوخية و السبانخ؟ \#شاركونا

$$
\begin{aligned}
& \text { ايش رايكم بصحن الخضروات هذا؟ }
\end{aligned}
$$

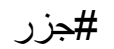

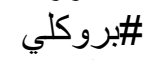

$$
\begin{aligned}
& \text { ز هرة/قرنبيط مشوية بالفرن مع شوية زيت زيتون }
\end{aligned}
$$

$$
\text { شبت نبادي قليل عبارة عن: }
$$

$$
\text { سوو هاوجربو ها وشاركو ها أهلكم في البيت وقولو النا حبيتو ها أولا }
$$




\section{Week 3 (Fruit pizza Challenge):}

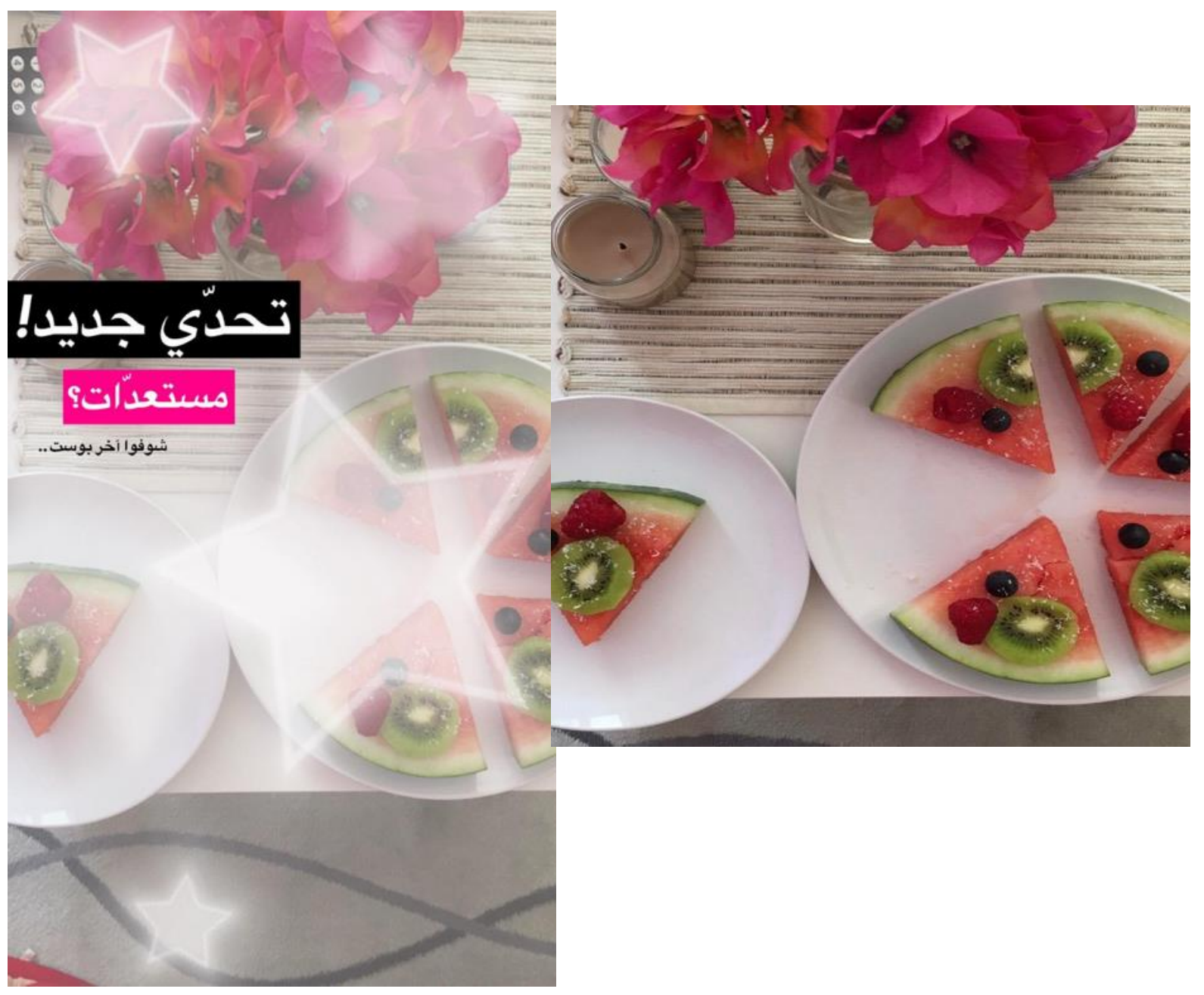

التحدي الثالث: تحدي بيتزا الفواكه

$$
\begin{aligned}
& \text { شاركونا إبداعاتكم في صنع بيتز أمن الفو اكه على هذا الهاثتاق }
\end{aligned}
$$

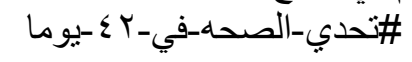

$$
\text { إبداعاتكم بعرضها هنا وبنسوي تصويت عليها تلفيها }
$$

الصورة اللي تحصل على أعلى تصويت بتفوز بقسيمة الثشر اء المجانية من الأمازون بقيمة بهو ريال

$$
\text { آخر يوم لاستقبال الصور هو يوم \#الاثنين القادم.. }
$$

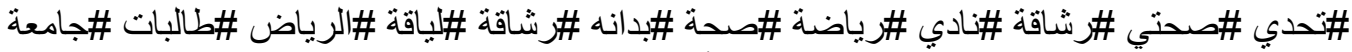
\#البات_جامعة_الأميره_نوره \#طألبات_جامعة_الأميرة_نورة \#تغذية \#تحافة \#سمنة \#سمنة \#ريجيم \#دايت

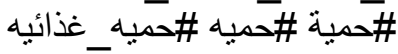




\section{Week 4 (Salad):}
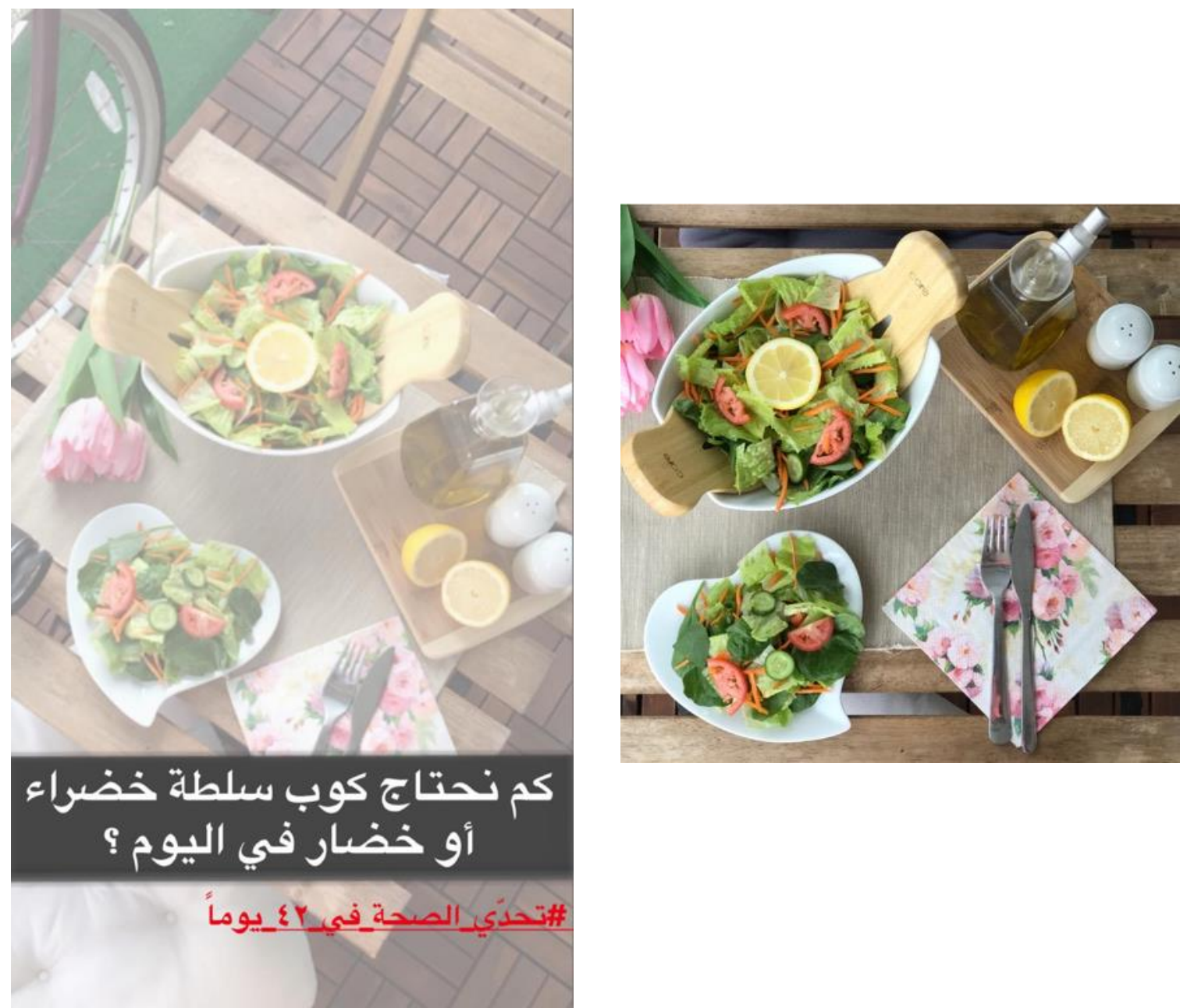

$$
\text { كم نحتاج من الخضروات اليوم في اليوم؟ }
$$

احتياجاتنا للخضرو ات في اليوم يعتمد على العمر و الجنس ومستوى الأداء الرياضي..

نحتاج كبالغين تقريباً [كوبين ونصف] في اليوم وهو احتياجينا اليومي اذا كنا ممن يمارس النشاط الحركي المتوسط

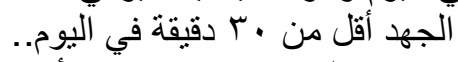

أما بالنسبة للأشخاص اللي يمارسون الرياضه قد يحتاجون أكثر مو كوبين ونصف في اليوم!

$$
\begin{aligned}
& \text { \#سؤال: الحصة الو احد من السلطة الخضر اء الطازجة تُعادل كم كوب؟ }
\end{aligned}
$$

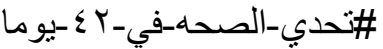

\#دي \#صحتي \#رشاقة \#نادي \#رياضة \#هحة \#بدانه \#رشاقة \#لياقة \#الرياض \#طالبات \#جامعة \#البات_جامعة_الامبره_نوره \#طالبات_جامعة_الأمبرة_نورة \#تغذية \#نحافة \#سمنة \#سمنة \#ريجيم \#دايت

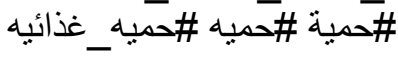




\section{Week 5 (Fruit Juice):}

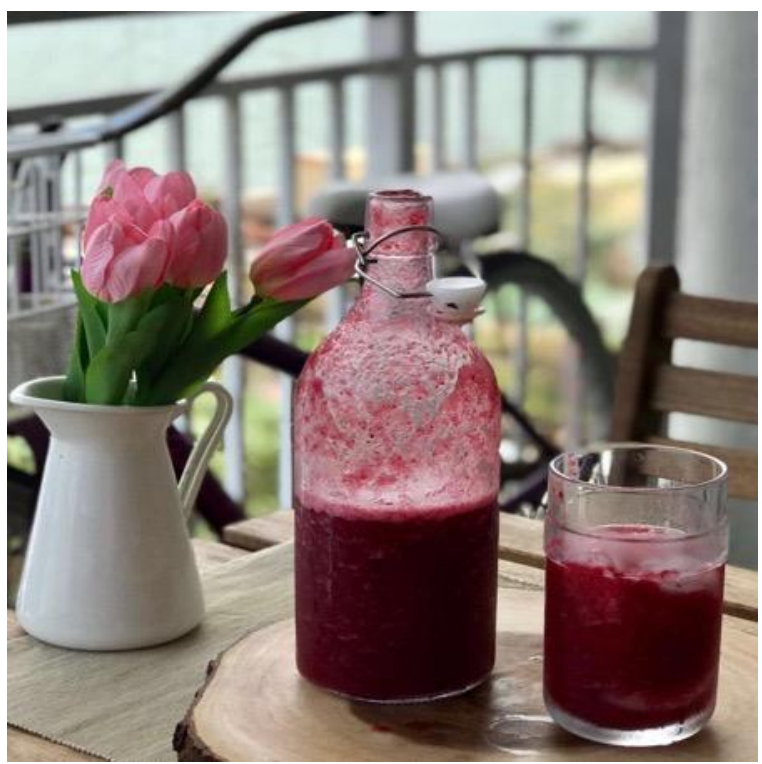

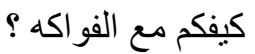

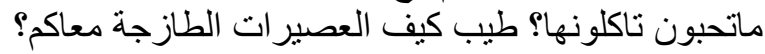

دخل الصيف ونحتاج مشروبات باردة .. خلونا بالعصيرات و الكوكتيلات الطازجة و ابتعدو ا عن المعلبات

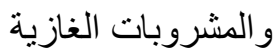

ايش نوع الفو اكة أو العصيرات الطازجة اللي تفضلونها؟

$$
\text { ! }
$$

جربوا هالعصير الباارد الطازج أو استبدلوه بالفواكه التي تحبون وشاركوه مع من تحبون.

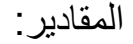

أناناس

توت أحمر

توت أسود

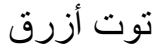

$$
\text { ربع كوب مويه }
$$

6

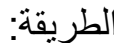

I ـ تغسل الفو اكة ويقطع الأناناس مكعبات صغيرة:

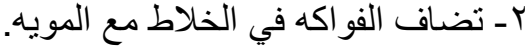

r- تخلط جميع المقادير مع بعض وتضع في في في الجلك المخصص.

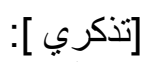

1 ا ابتعدي عن اضافة السكر واستبدليه بالموز .

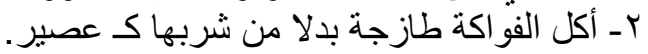

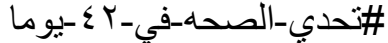

!

\#دي \#تحني \#رشاقة \#نادي \#رياضة \#صحة \#بدانه \#رشاقة \#لياقة \#الرياض \#طالبات \#جامعة

\#طالبات_جامعة_الاميره_نوره \#طالبات_جامعة_الأميرة_نورة \#تغذية \#نحافة \#سمنة \#سمنة \#ريجيم \#دايت (حمية \#ميه \#تمبه غذائيه 


\section{Week 6:}

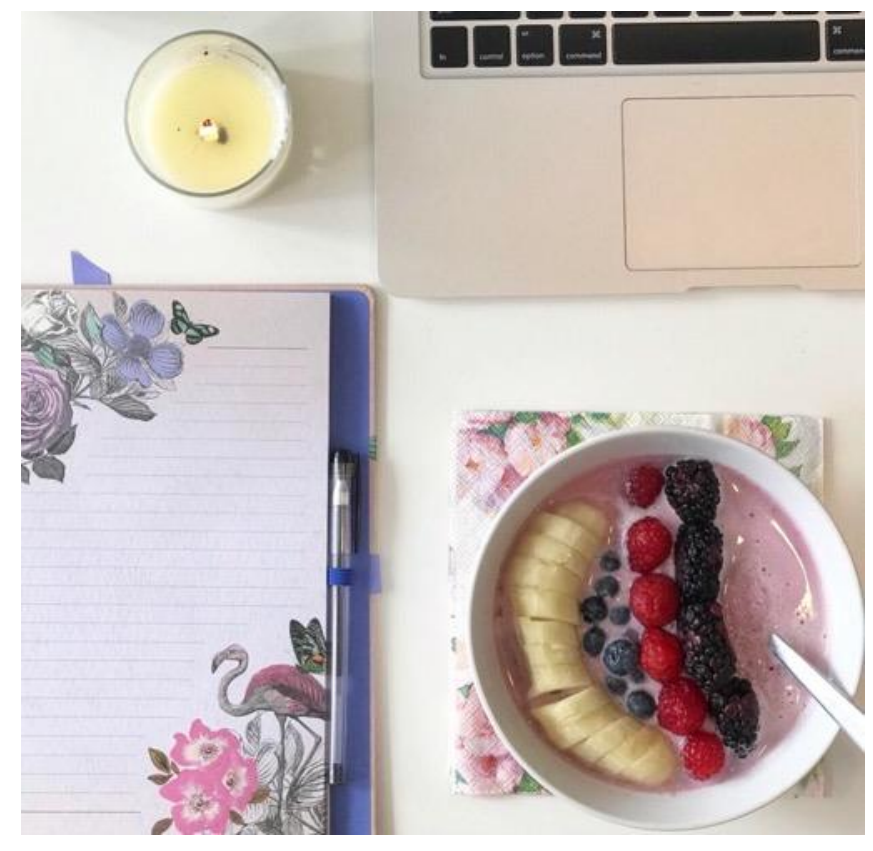

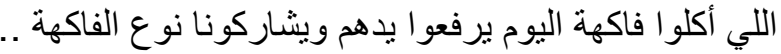

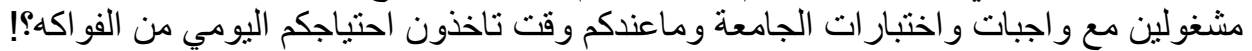

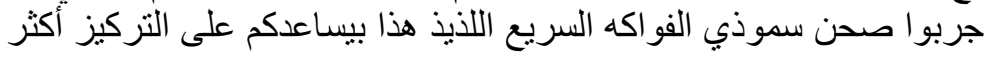

الفو اكة لا تحتوي فقط على الكربو هيدرات اللي نم تمدنا بالطاقة بل هي غنية بالفيتامينات و المعادن الضروريه

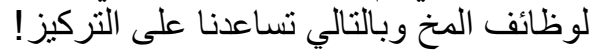

$$
\begin{aligned}
& \text { المقادير : - أن } \\
& \text { أناناس } \\
& \text { توت أزرق } \\
& \text { توت أسود } \\
& \text { نص حبة موزة } \\
& \text { ربع كوب زبادي قليل الدسم } \\
& \text { ربع كوب مويه }
\end{aligned}
$$

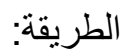

توضع الفو اكة بعد غسلها وتقطيعها في الخلاط مع الزبادي و المويه ثم توضع في صحن وتزين على طريقتلك

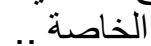

جربو ها وشاركونا الفو اكة المستخدمة

|تحدي-الصحه-في-بك -يوما 


\section{Topic 4 "Social Support"}

\section{Week 1 (Fruit Basket / Challenge):}

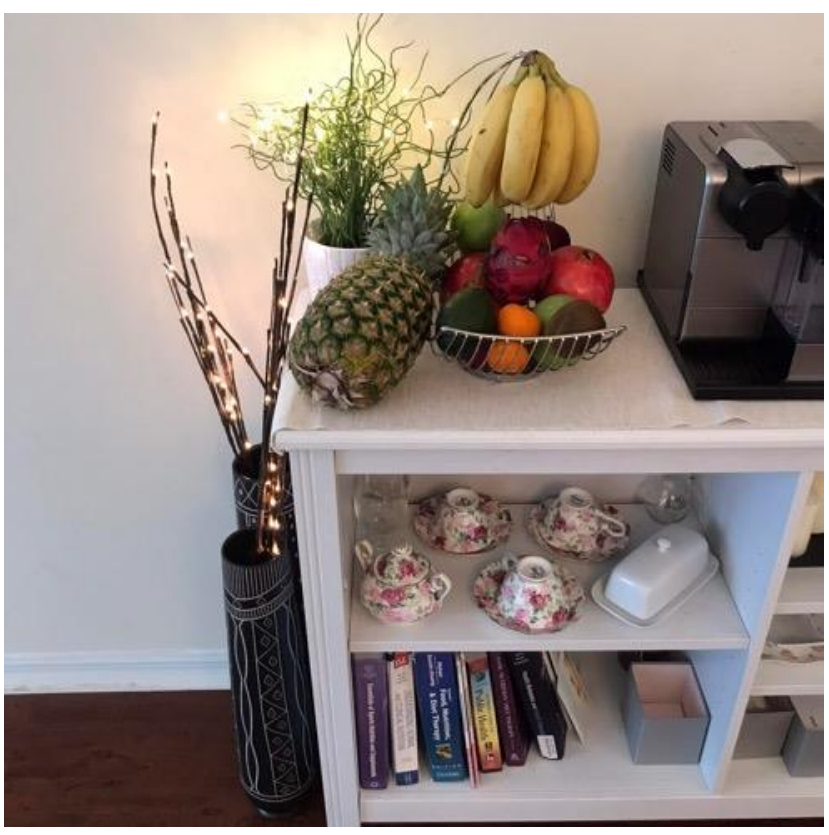

تحدي هالأسبوع هو تحدّي \#سلة الفواكه

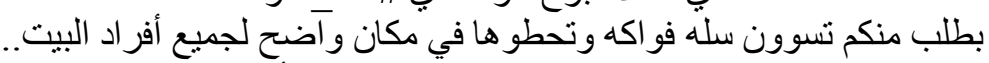

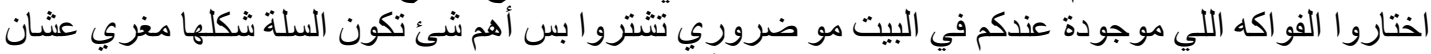
تغري بقية أفرد البيت

ممكن تكون فاكهة وحده بس ترتبيها بشكل حلو داخل سله أو صندو اليدوق و وتحطو ها في مكان يوصله الجميع!

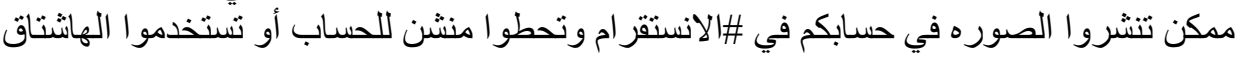

\#تحدي_الصحة في_rع_يوما وبكذ ا تكونوا أفدتو ا صديقاتكم ومعار فكم كمان!

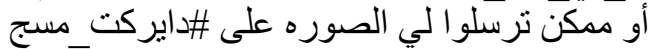

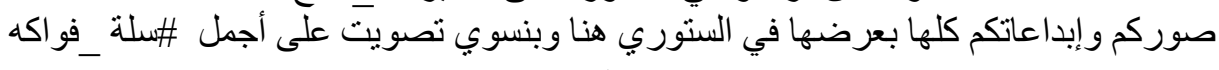

$$
\text { أخر يوم لاستلام الصور هو الثلثاء القادم ! }
$$

$$
\text { يلا ورونا ابداعاتكم }
$$




\section{Week 2 (Gym):}
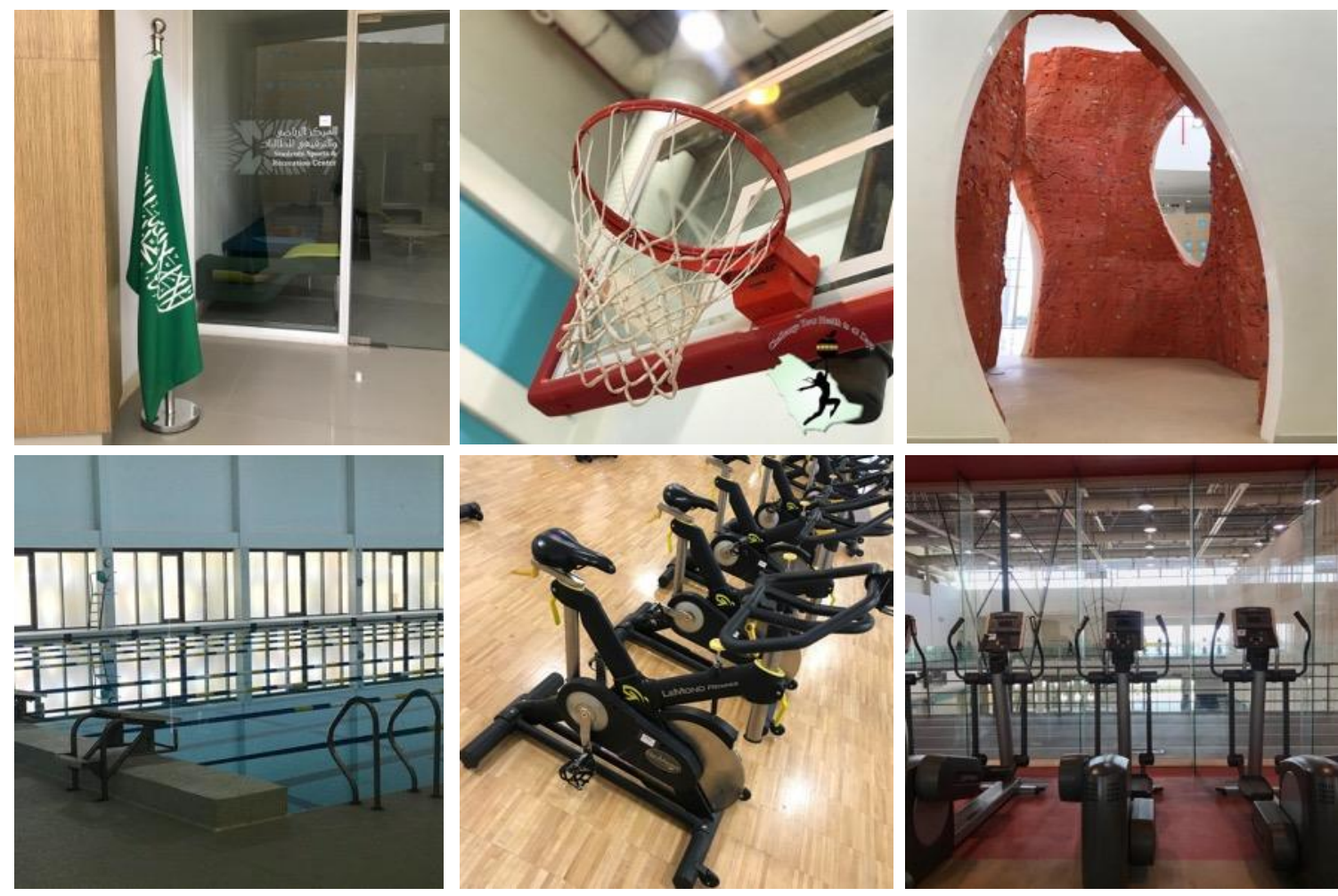

$$
\text { اللي مسجلة في نادي الجامعة أو قد سجلت قبل ترفع يدها ? }
$$

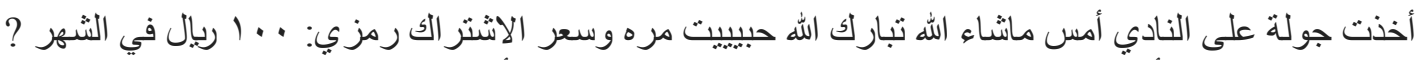

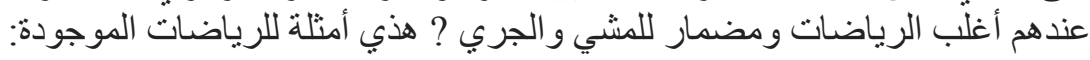
ملعب كرة سلّة كسبح كبير جداً كلاسات سبينينق

كلاسات للتمارين الرياضية رياضة التسلّق و غير ها الكثيبير..

حبيت فكرة الفرق اللي مسوينها حلو نروحين انت وصديقاتك وتتنافسون على شي حلو \#تاق أو \#منشن لصديقتلك اللي تبين تروحين للنادي معاها

$$
\text { \#تحدّي_الصحة_في_rع_يوماً }
$$

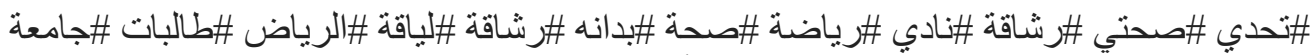

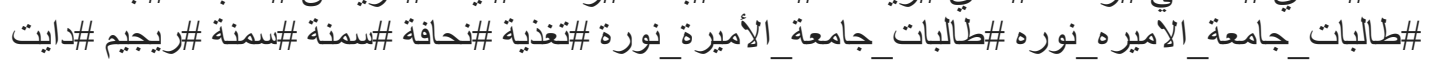
\#حمية \#حميه \#حميه غذائيه 


\section{Week 3 (Walking with a Friend):}

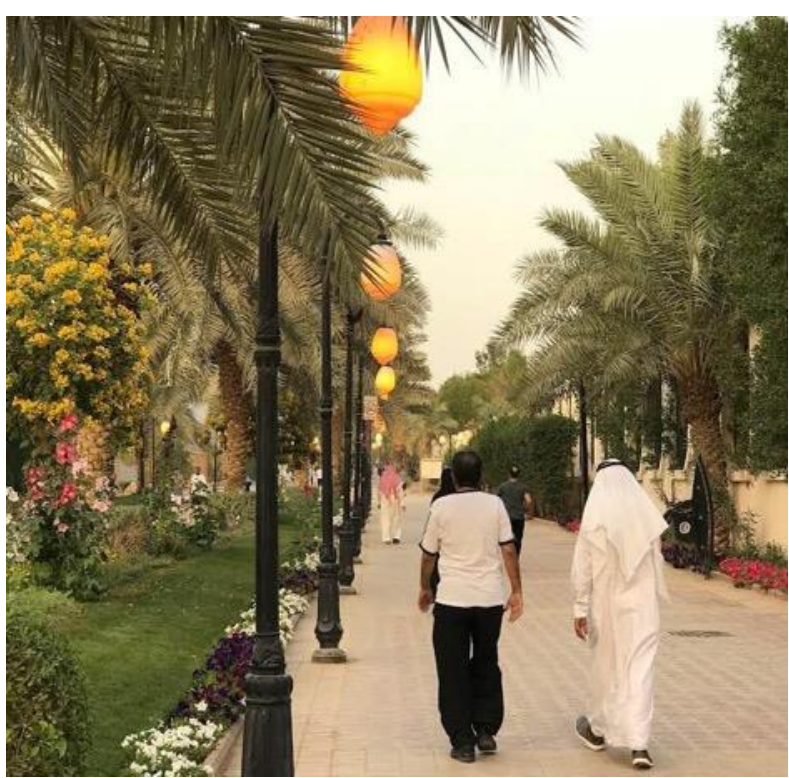

$$
\text { الناس اللي دائماً تختلقي الأعذار عثان ماتسوين رياضة؟ }
$$

عندي لكم طريقة ? إنبق

ايش رايكم هالويك اند نستبدل خرجتنا مع صحباتنا لُمشىى ؟ أو ايش رايكم تقترحون على أختلك أو أملك في البيت

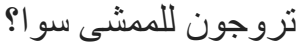

الجو هالأيام لسا مقبول الحمدله الحقو ا قبل يبدأ الصيف فعلياً الى أن تُصبح عادة عندكم وتستمروا حتى لو اشتد الحر

\section{$\square)$ :}

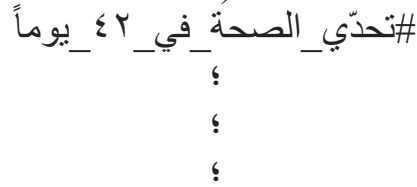

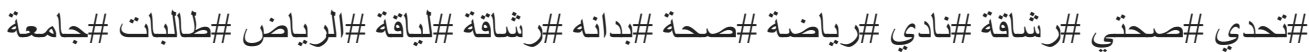

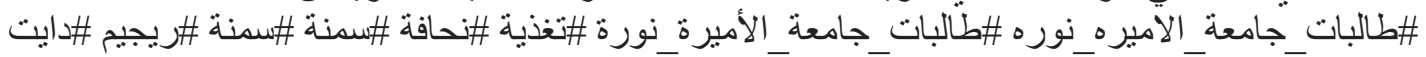

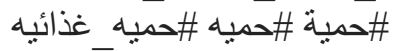




\section{Week 4 (Cooking with Siblings):}

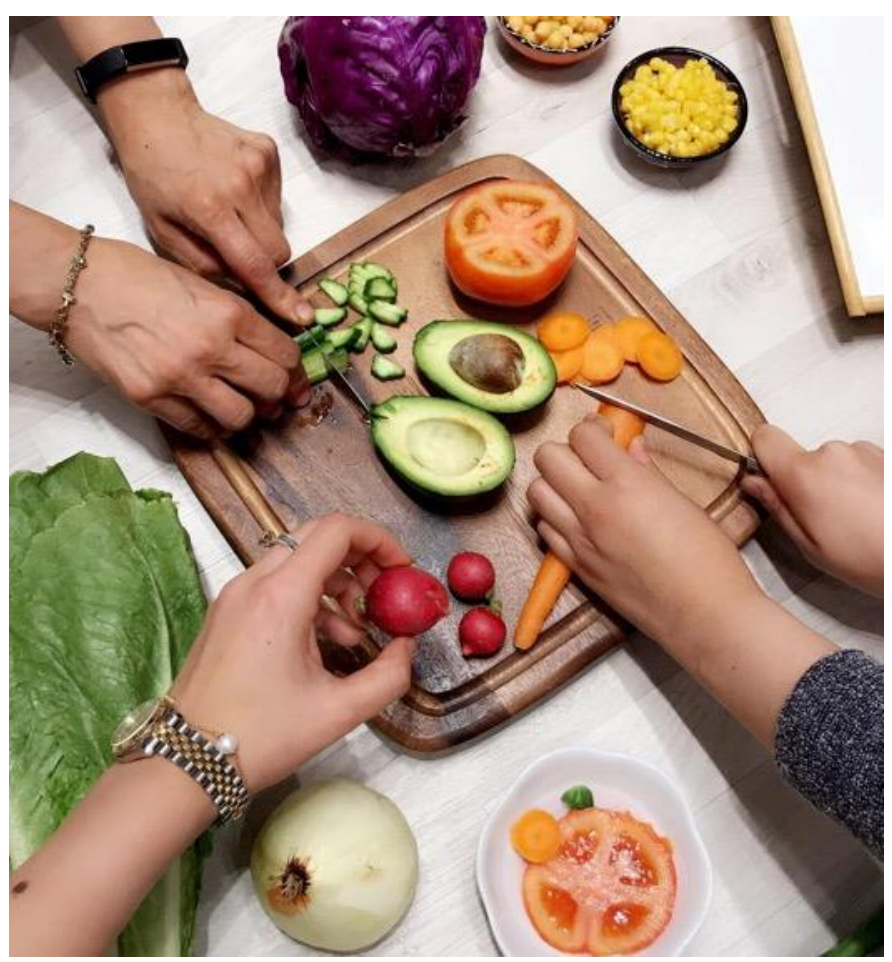

فكرنو ا مره تدخلو ا المطبخ مع الو الدة أو مع أخو اتكم وتسوون طبخة صحية أو غير صحية ؟

بما انه أمس تكلمنا عن الخضروات وفو ائدها قررت أناو أمي وأختي نتشارك في تقطيع السلطة !

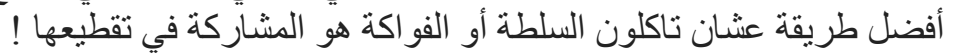
حتى أخو اتكم الصغار خلو هم يشاركوكم الطبخ أو التقطيع!

أنا اخترت السلطة كطبق صحي أشنارك في إعداده أنا وأهلي .. انتوا ايش بتختاروا أرسلو الي أب طبق تعدّيه انتِ

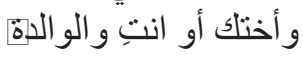

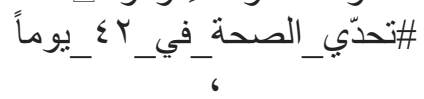

\#تحدي \#صحتي \#رشاقة \#نادي \#رياضة \#صحة \#بدانه \#ةشاقة \#لياقة \#الرياض \#ة \#طالبات \#جامعة \#طالبات_جامعة الأميره_نوره \#طالبات_جامعة الأميرة_نورة \#تئنذية \#نحافة \#سمنة \#سمنة \#ريجيم \#دايت \#مية \#حميه \#حميه_ غذائيه 
Week 5 (Jump Rope):

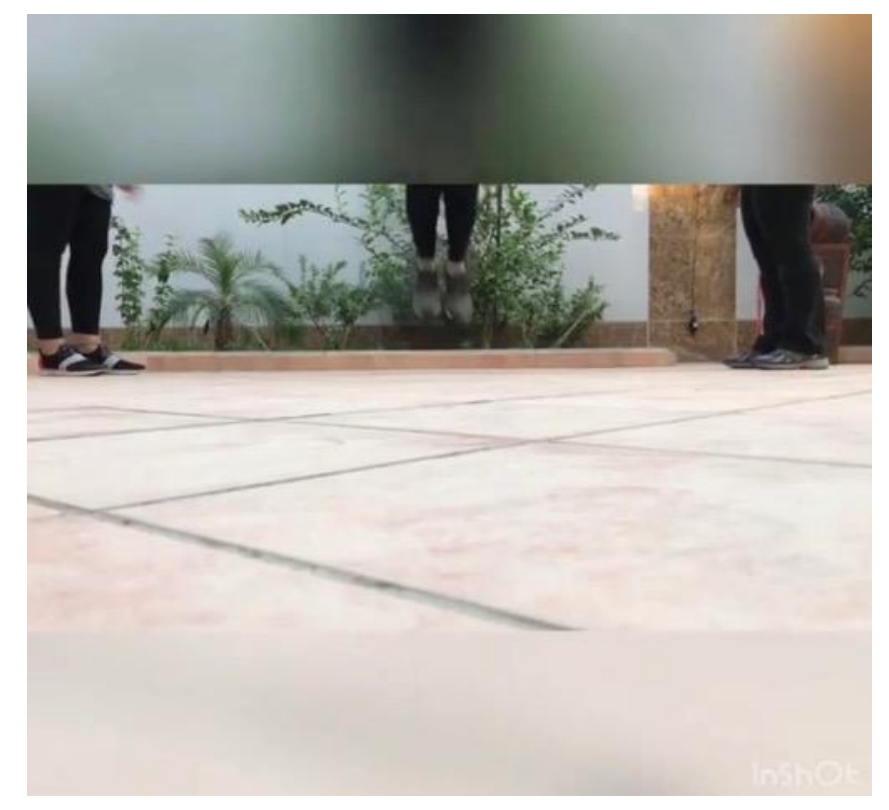

\footnotetext{
فاكرين شـبره أمره شمس نجوم

طيب فاكرين الأسـبوع اللي راح ايش قلنا عن رياضة الحبل؟ لئبره

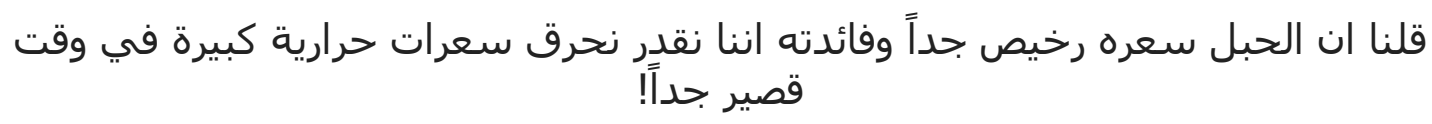

وقلنا بعد ان خلال · ا دقايق فقط تقدروا تحرقوا . ․ سعرة حرارية ?

جربوا ألعبوها هالمرة مع أخواتكم في البيت أو صديقاتكم وشجعوا بعض

\#تحدي_الصحة_في_rع_يوماً

6

\#تحدي \#صحتي \#رشاقة \#نادي \#رياضة \#صحة \#بدانه \#رشاقة \#لياقة \#الرياض الاض

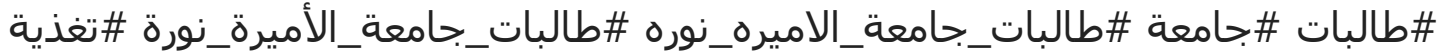

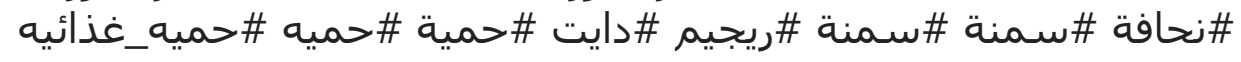


Week 6 (Walking with Family):

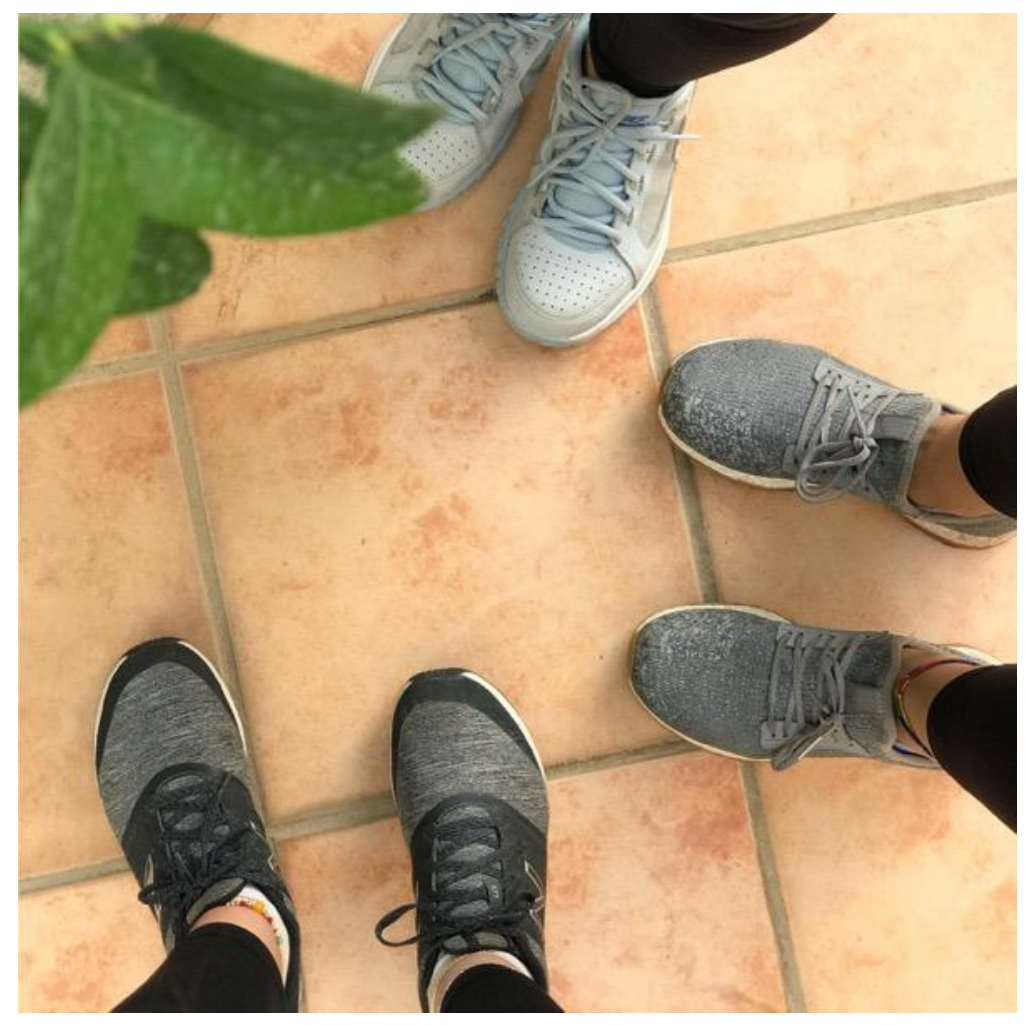

$$
\begin{aligned}
& \text { ايش نوع الرياضة اللي سويتو ها اليومج }
\end{aligned}
$$

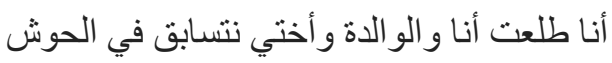

$$
\begin{aligned}
& \text { الجو هالأيام يحمّس للجري و المشي في الحوش.. }
\end{aligned}
$$

حمّسو ا أخو اتكم واطلعو ا تسابقو ا في الحوش وخلو هم يحمّلو ا تطبيق عداد الخطو ات معات معاكم وتنافسو ا مين الأكثر خطوة ? خلمبل

$$
\text { _اللي تطبق الكلام ترفع يدها ?! }
$$




\section{Topic 5 "Self Monitoring \& Self Regulation"}

\section{Week 1:}

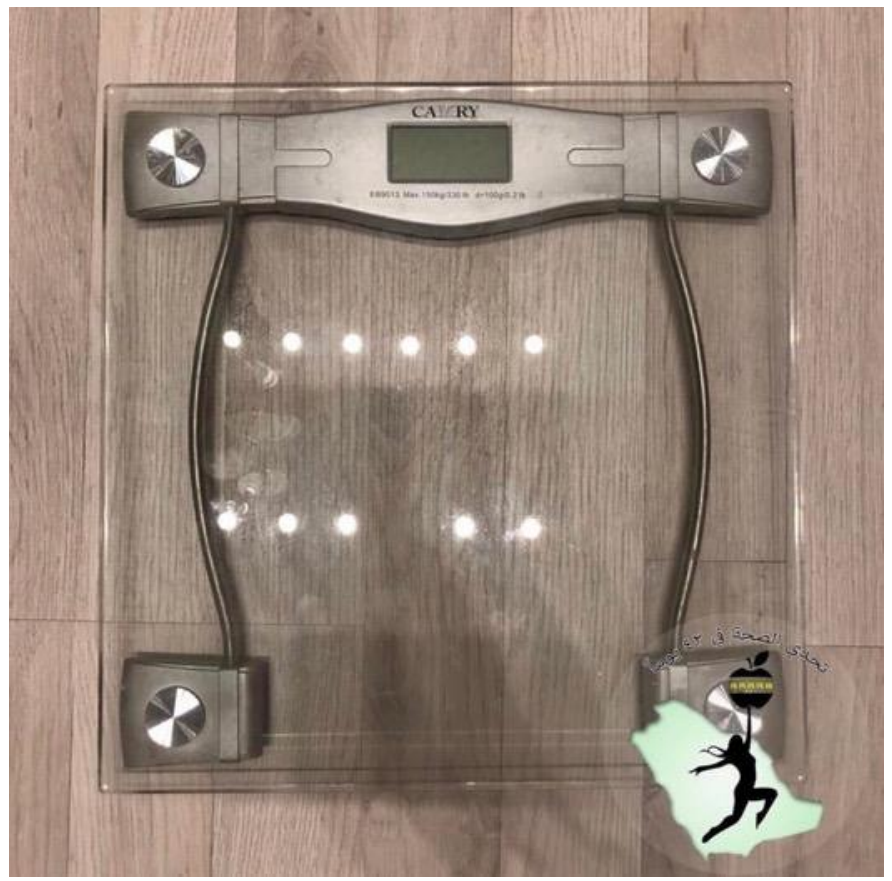

$$
\begin{aligned}
& \text { عندكم علم بأن الوزن يتغير خلال اليوم؟ } \\
& \text { أفضل طريقة لقياس الوزن هي قياسه مرة و احدة كل أسبوع! } \\
& \text { [تدكري]: قياس وزنك كل أسبوع يساعدلك في الوصول الى هدفلك } \\
& \text { \#تحدي_الصحة_في_rی__يوماً }
\end{aligned}
$$

\#تغذية \#تحدي \#صحة \#وزن \#وزني \#الرياض \#طالبات \#سمنة \#رشاقة \#نحافة \#فو اكة \#خضرو ات \#رياضة _وزن \#وزن _مثالي \#جامعة_الأميرة_نورة \#جامعة_الاميرة_نوره 


\section{Week 2 (Challenge):}

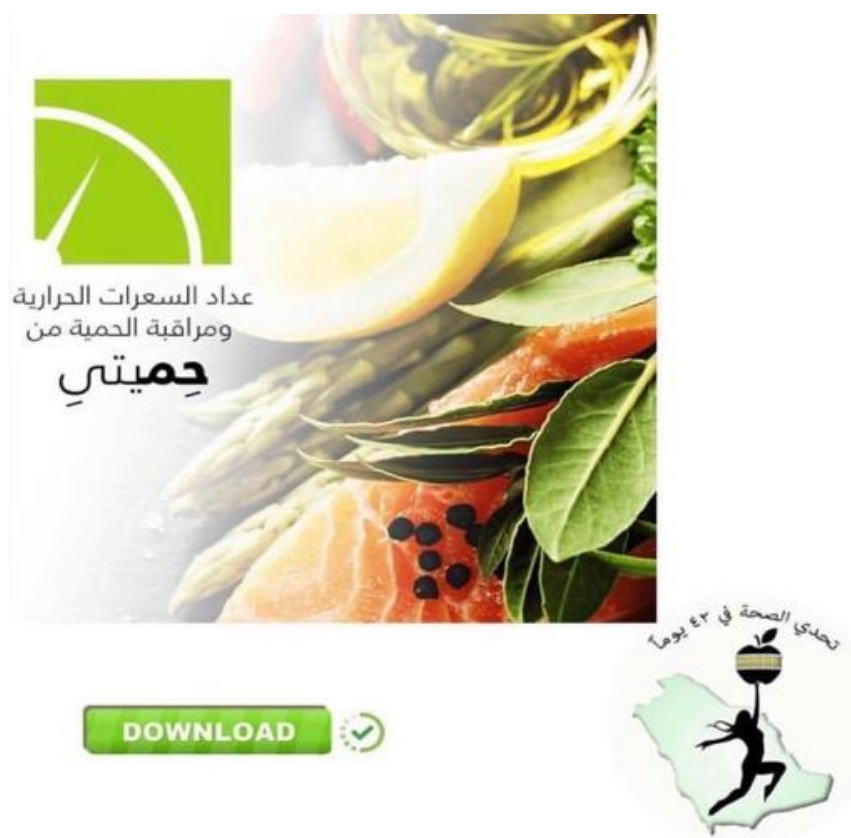

$$
\text { ماسألتوا عن تحدّي هالأسبوع }
$$

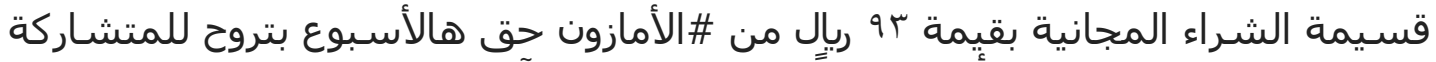

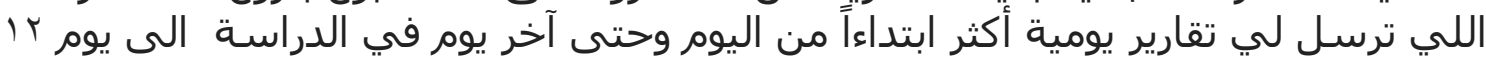

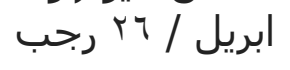

$$
\text { \#تحدّي_الصحة_في_ا_rیقيوماً }
$$

!

\#تحي \#صحتي \#رشاقة \#نادي \#رياضة \#صحة \#بدانه \#رشاقة \#لياقة \#الرياض

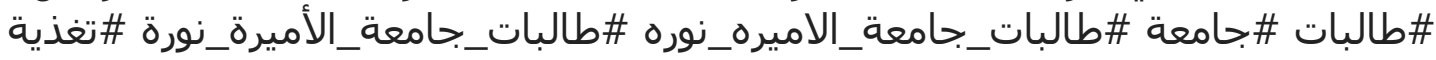

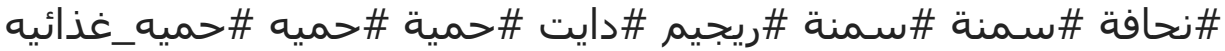




\section{Week 3 (Sharing is Caring):}

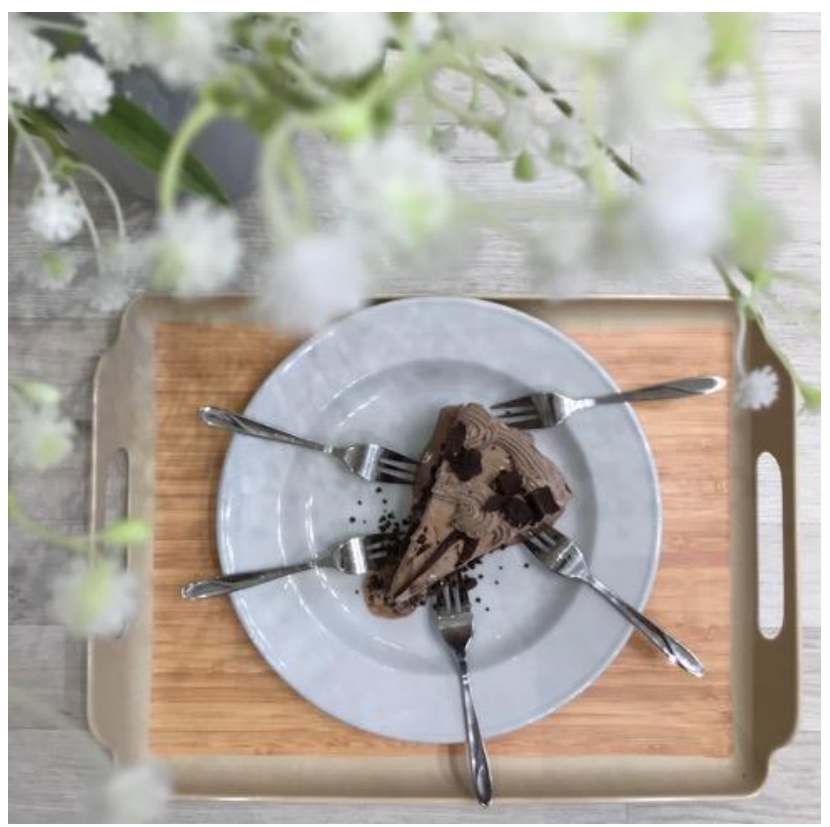

مين تحب الكيك وحارمة نفسها هالأيام عشان ينزل وزنها؟

الآن من يوم بدأنا كمّلنا ب أسابيع مع بعض الحمدلله تستاهلون قطعة كيك مكافأه لكم ?

6

أحسن شي اننا مانحرم نفسنا من شئ لكن نر اقب نفسنا ونر اقب الكميات اللي ناكلها خلال اليوم !

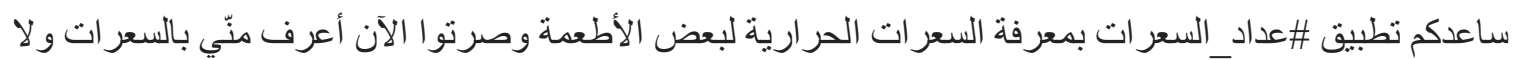
? ل

اليوم ويكك اند مافي مشكلة لو تشاركنا قطعة كيك سو ا مع من نُجِبَ

6

نهاية اسبوع سعيدة:

!

\#تحدي \#صحتي \#رشاقة \#نادي \#رياضة \#صحة \#بدانه \#رشاقة \#لياقة \#الرياض \#طالبات \#جامعة الاضة

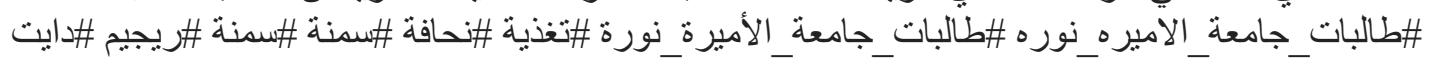
\#مية \#حميه \#حميه غذائيه 


\section{Week 4:}
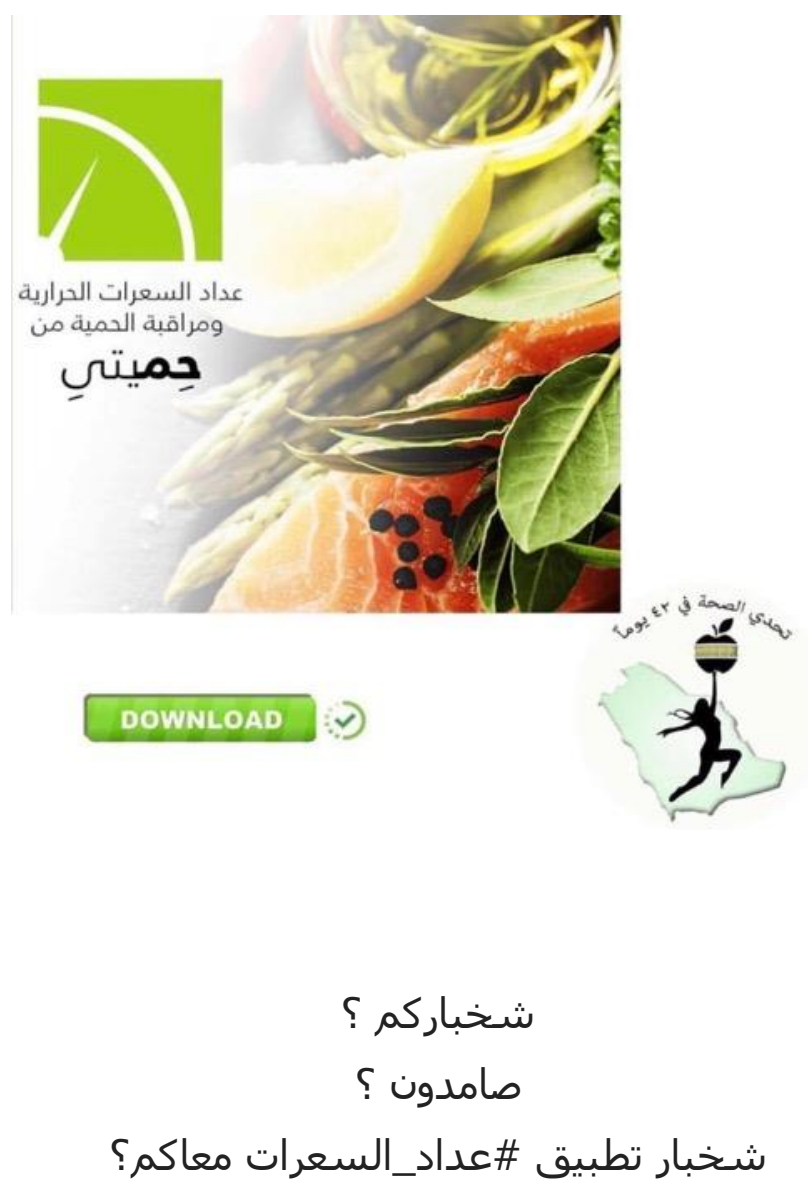

نهاية أسبوع وكلنا غالباً عندنا مناسبات ونخربها شـوي! مو مشكلة كلوا بس لا تخربوا اللي

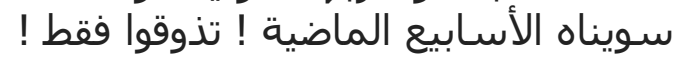

ولا تنسون تدخلون اللي تاكلونه في التطبيق..

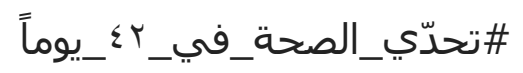

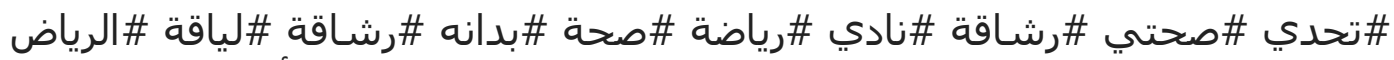

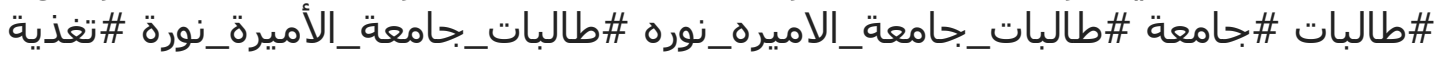
\#حافة \#سمنة \#سمنة \#ريجيم \#دايت \#حمية \#)حميه \#حميه_غذائيه 


\section{Week 5:}

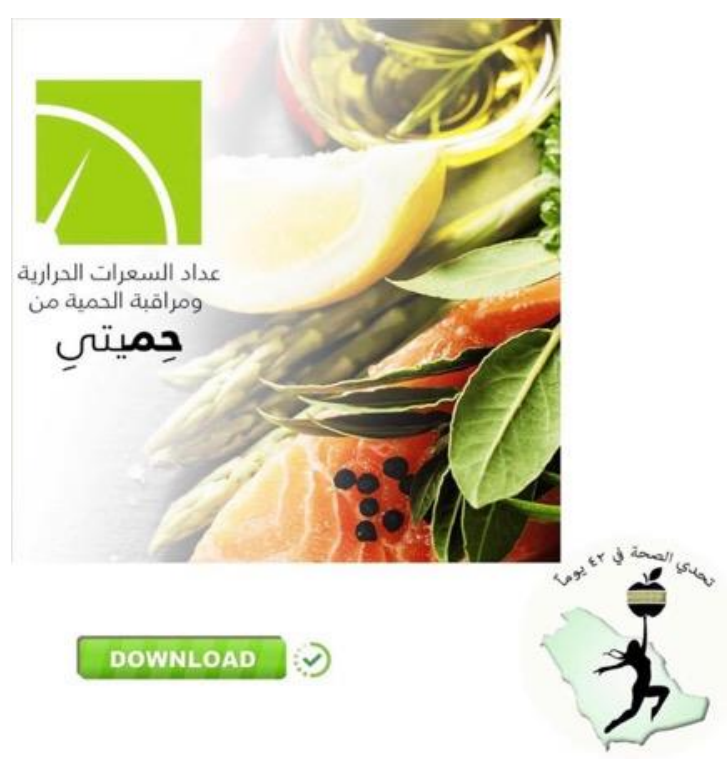

$$
\text { شخباركم }
$$

أدري نهاية أسـبوع وكلنا نخربط بس لاتنسون تدخلون اللي تناولتوه اليوم وفي الأيام القادمة..

كيف التطبيق معاكم؟ استفدتوا منه؟ ساعدكم في معرفة السعرات الحرارية؟

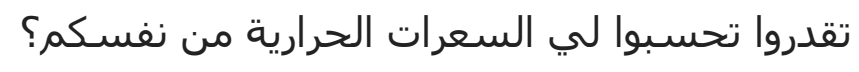

وكيف تطبيقات عداد الخطوات؟ تراقبوا نتائجكم يومياً!

$$
\begin{aligned}
& \text { لاتهدموا اللي بنيتوه ال ه أسابيع اللي راحت } \\
& \text { ماشـاء الله قدمتوا جهد تشـكرون عليه }
\end{aligned}
$$

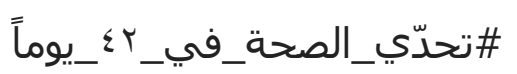




\section{Week 6:}
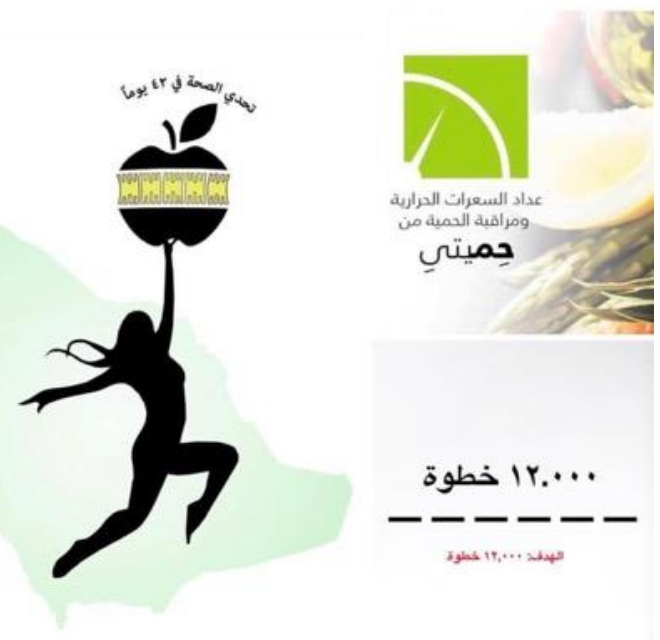

الحمدلله خلّصنا 7 أسابيع مع بعض

أتمنى إنكم استمتعوا واستفدتوا جميعاً بالأسابيع الماضية بعصة إسنا

أتمنى تحافظون على الأشياء التالية وماتخربون اللي بنيتوه الفترة السابقة: - أكل الخضار والفواكه يومياً ( (^-^ حصص يومياً) لنتجنب الأمراض المزمنة والإمساك والسمنة.

$$
\text { - مراقبة الخطوات اليومية. }
$$

- ادخال الأكل بشكل يومي في تطبيق عداد السعرات الى أن تتمكني من معرفة

السعرات الحرارية فيطبيق الموجودة في كل وجبة.

$$
\text { - وزن الجسم أسـبوعياً وليس يومياً. }
$$

6

باذذن الله بكون متواجدة طوال الأسـبوع القادم لأخذ قياساتكم مرة أخرى.. تحدّي_الصحة_في_آبــيوماً 
Appendix 10.

Satisfaction Scale

\begin{tabular}{|l|l|l|l|l|}
\hline \multicolumn{1}{|c|}{ Item } & Disagree & Natural & Somewhat Agree & Agree \\
\hline $\begin{array}{l}\text { Did the daily food log help you } \\
\text { think about your portions? }\end{array}$ & & & & \\
\hline $\begin{array}{l}\text { I will continue using the self- } \\
\text { tracking app or any similar app }\end{array}$ & & & & \\
\hline $\begin{array}{l}\text { Instagram pictures/videos motivated } \\
\text { me to consume fruits and vegetables }\end{array}$ & & & & \\
\hline $\begin{array}{l}\text { Instagram topics motivated me to } \\
\text { consume fruits and vegetables }\end{array}$ & & & & \\
\hline $\begin{array}{l}\text { In general, Instagram posts were } \\
\text { interested and helpful }\end{array}$ & & & & \\
\hline $\begin{array}{l}\text { I will participate in a similar study } \\
\text { in future }\end{array}$ & & & & \\
\hline $\begin{array}{l}\text { I will encourage my friends and } \\
\text { relatives to participate in similar } \\
\text { research }\end{array}$ & & & & \\
\hline $\begin{array}{l}\text { I will continue applying what I've } \\
\text { learned }\end{array}$ & & & & \\
\hline $\begin{array}{l}\text { In general, the study was easy } \\
\text { were annoying }\end{array}$ & & & & \\
\hline $\begin{array}{l}\text { Using multiple apps in the study } \\
\text { and }\end{array}$ & & & & \\
\hline
\end{tabular}


Appendix 11.

Modified Nutrition Knowledge Questionnaire

The first few items are about what advice you think experts are giving us

1- How many servings of fruit and vegetables a day do you think experts are advising people to eat? (One serving could be, for example, an apple or a handful of chopped carrots)

1- Do you think these are high or low in protein? (tick one box per food)

1. Chicken

2. Cheese

3. Fruits

4. Baked beans

5. Butter

6. Cream

2- Do you think these are high or low in fiber? (tick one box per food)

1. Corn flakes

2. Bananas

3. Eggs

4. Red meat

5. Broccoli

6. Nuts

7. Fish

8. Baked potatoes with skin

9. Chicken

10. Baked beans

3- A glass of unsweetened fruit juice counts as a helping of fruit.

1. Agree

2. Disagree

3. Not sure 
4- There is more protein in a glass of whole milk than in a glass of skimmed milk.

1. Agree

2. Disagree

3. Not sure

5- Which of these breads contain the most vitamins and minerals? (tick one)

1. White

2. Brown

3. Wholegrain

4. Not sure

This section is about health problems or diseases

6- Do you think these help to reduce the chances of getting certain kinds of cancer?

1. Eating more fiber

2. Eating less sugar

3. Eating less fruit

4. Eating less salt

5. Eating more fruit and vegetables

6. Eating less preservatives/additives

7- Do you think these help prevent heart disease? (answer each one)

1. Eating more fiber

2. Eating less saturated fat

3. Eating less salt

4. Eating more fruit and vegetables

5. Eating less preservatives/additives 
Appendix 12.

Additional Nutrition Knowledge Questionnaire "Post-Intervention"

1. Myplate consists of carbohydrates, fruits, vegetables, and meat. The largest amount is:

1. Meats

2. Carbohydrates

3. Vegetables

4. Fruits

2. How many servings of fruits the adult needs per day ( 1 serving= 1 apple)

1. 1-2 servings

2. 2-3 servings

3. 3-4 servings

4. 5-6 servings

3. How many cups of vegetables does an adult need daily?

1. 1 cup

2. 2 cups

3. $2 \frac{1}{2} \operatorname{cup}$

4. 3 cups

4. Non meat protein sources includes: (you can select more that 1 option)

1. Lentils

2. Hummus

3. Peas

4. Beans

5. Foul

5. How many calories should not be exceeded in a snack?

1. Not more than 50 calories

2. Not more than 100 calories

3. Not more than 150 calories 
6. Give examples of 3 snacks.

7. How many calories in a cup of rice?

1. 50

2. 80

3. 100

4. 120

8. How many calories you could burn after 15 minutes of taking the stairs?

1. 50

2. 100

3. 150

4. 200

9. How many calories you could burn jump in a minute??

1. 10

2. 15

3. 20 
Appendix 13.

Social Support and Eating Habits Survey "Family"

Please rate each question twice. Under family, rate how often anyone living in your household has said or done what is described during the last three months. Under friends, rate how often your friends, acquaintances, or cow orkers have said or done what is described during the last three months.

During the past three months, my family (or members of my household):

i. Encouraged me not to eat "unhealthy foods" (cake, salted chips) when I'm tempted to do so

ii. Discussed my eating habit. Changes with me (asked me how I'm doing with my eating changes)

iii. Reminded me not to eat high fat, high salt foods

iv. Complimented me on changing my eating habits ("Keep it up", "We are proud of you ")

v. Commented if I went back to my old eating habits

vi. Ate high fat or high salt foods in front of me

vii. Refused to eat the same foods I eat

viii. Brought home foods I'm trying not to eat

ix. Got angry when I encouraged them to eat low salt, low fat foods

x. Offered me food I'm trying not to eat 
Appendix 14.

Social Support and Eating Habits Survey "Family"

Please rate each question twice. Under family, rate how often anyone living in your household has said or done what is described during the last three months. Under friends, rate how often your friends, acquaintances, or coworkers have said or done what is described during the last three months.

During the past three months, my friends:

i. Encouraged me not to eat "unhealthy foods" (cake, salted chips) when I'm tempted to do so

ii. Discussed my eating habit. Changes with me (asked me how I'm doing with my eating changes):

iii. Reminded me not to eat high fat, high salt foods

iv. Complimented me on changing my eating habits ("Keep it up", "We are proud of you ")

v. Commented if I went back to my old eating habits

vi. Ate high fat or high salt foods in front of me

vii. Refused to eat the same foods I eat

viii. Brought home foods I'm trying not to eat

ix. Got angry when I encouraged them to eat low salt, low fat foods

x. Offered me food I'm trying not to eat 
Appendix 15.

Social Support and Exercise Survey "Family"

Below is a list of things people might do or say to someone who is trying to exercise regularly. If you are not trying to exercise, then some of the questions may not apply to you, but please read and give an answer to every question.

Please rate each question twice. Under family, rate how often anyone living in your household has said or done what is described during the last 6 weeks. Under friends, rate how often your friends, acquaintances, or coworkers have said or done what is described during the last six weeks.

Please write one number from the following rating scale in each space:

\section{Family}

i. Exercised with me

ii. Offered to exercise with me

iii. Gave me helpful reminders to exercise ("Are you going to exercise tonight?")

iv. Gave me encouragement to stick with my exercise program

v. Changed their schedule so we could exercise together

vi. Discussed exercise with me

vii. Complained about the time I spend exercising

viii. Criticized me or made fun of me for exercising

ix. Gave me rewards for exercising (bought me something or gave me something I like)

$\mathrm{x}$. Planned for exercise on recreational outings

xi. Helped plan activities around my exercise

xii. Asked me for ideas on how they can get more exercise

xiii. Talked about how much they like to exercise 
Appendix 16.

Social Support and Exercise Survey "Friends"

Below is a list of things people might do or say to someone who is trying to exercise regularly. If you are not trying to exercise, then some of the questions may not apply to you, but please read and give an answer to every question.

Please rate each question twice. Under family, rate how often anyone living in your household has said or done what is described during the last 6 weeks. Under friends, rate how often your friends, acquaintances, or coworkers have said or done what is described during the last six weeks.

Please write one number from the following rating scale in each space:

\section{Friends}

i. Exercised with me

ii. Offered to exercise with me

iii. Gave me helpful reminders to exercise ("Are you going to exercise tonight?")

iv. Gave me encouragement to stick with my exercise program

v. Changed their schedule so we could exercise together

vi. Discussed exercise with me

vii. Complained about the time I spend exercising

viii. Criticized me or made fun of me for exercising

ix. Gave me rewards for exercising (bought me something or gave me something I like)

$\mathrm{x}$. Planned for exercise on recreational outings

xi. Helped plan activities around my exercise

xii. Asked me for ideas on how they can get more exercise

xiii. Talked about how much they like to exercise 


\section{Appendix 17.}

\section{Eating Habits Confidence Survey / Self Efficacy}

Below is a list of things people might do while trying to change their eating habits. We are mainly interested in salt and fat intake, rather than weight reduction.

Whether you are trying to change your eating habits or not, please rate how confident you are that you could really motivate yourself to do things like these consistently, for at least six months.

Please circle one number for each item: How sure are you that you can do these things?

i. Get up early, even on weekends, to exercise

ii. Stick to your low fat, low salt foods when you feel depressed, bored, or tense

iii. Stick to your low fat, low salt foods when there is high fat, high salt food readily available at a party

iv. Stick to your low fat, low salt foods when dining with friends or co-workers

v. Stick to your low fat, low salt foods when the only snack close by is available from a vending machine

vi. Stick to your low fat, low salt foods when you are alone, and there is no one to watch you

vii. Cook smaller portions so there are no leftovers

viii. Eat lunch as your main meal of the day, rather than dinner

ix. Eat smaller portions of food at a party

x. Eat salads for lunch

xi. Add less salt than the recipe calls for

xii. Eat unsalted peanuts, chips, crackers, and pretzels

xiii. Avoid adding salt at the table

xiv. Eat unsalted, unbuttered popcorn

xv. Keep the salt shaker off the kitchen table

xvi. Eat meatless (vegetarian) entrees for dinner

xvii. Substitute low or non-fat milk for whole milk at dinner

xviii. Cut down on gravies and cream sauce

xix. Eat poultry and fish instead of red meat at dinner

xx. Avoid ordering red meat (beef, pork, ham, lamb) at restaurants

\begin{tabular}{|cc|cc|c|c|}
\hline I know I & cannot & \multicolumn{2}{|c|}{ Maybe I can } & I know I can & Does not apply \\
\hline 1 & 2 & 3 & 4 & 5 & 8 \\
\hline
\end{tabular}


Appendix 18.

\section{Exercise Confidence Survey / Self Efficacy}

Below is a list of things people might do while trying to increase or continue regular exercise. We are interested in exercises like running, swimming, brisk walking, bicycle riding, or aerobics classes.

Whether you exercise or not, please rate how confident you are that you could really motivate yourself to do things like these consistently, for at least six months.

Please circle one number for each question. How sure are you that you can do these things?

i. Get up early, even on weekends, to exercise

ii. Stick to your exercise program after a long, tiring day at work

iii. Exercise even though you are feeling depressed

iv. Set aside time for a physical activity program; that is, walking, jogging. swimming, biking, or other continuous activities for at least 30 minutes, 3 times per week

v. Continue to exercise with others even though they seem too fast or too slow for you

vi. Stick to your exercise program when undergoing a stressful life change (e.g., divorce, death in the family, moving)

vii. Stick to your exercise program when you have household chores to attend to

viii. Stick to your exercise program even when you have excessive demands at work

ix. Stick to your exercise program when social obligations are very time consuming

x. Read or study less in order to exercise more

\begin{tabular}{|cc|cc|c|c|}
\hline I know I & cannot & \multicolumn{2}{|c|}{ Maybe I can } & I know I can & Does not apply \\
\hline 1 & 2 & 3 & 4 & 5 & 8 \\
\hline
\end{tabular}




\section{Appendix 19.}

\section{Food Frequency Questionnaire}

The following food frequency questionnaire is designed to estimate you usual eating pattem. For each food listed, check the box indication how often during the past year you usually ate the amount specified in the parentheses.

If you ate a food only at certain times of year (ex. summer), average your intake over the year. The pattern you report should reflect usual eating habits no the pattern of a short term diet, some other unusual circumstance, or what you think you should eat.

The boxes include monthly, weekly and daily categories:

Never or (about) less than once a month ( $<1 /$ month)
$1-3$ (times) per month
1 per week (about once a week)
$2-4$ (times) per week
$5-7$ times a week (or about once a day)
$2-3$ times a day
$4+$ times a day

Note that the "5-7 times a week" category is a frequency pattern of about "once a day".

For example, foods you never or rarely eat would be checked "never". A food eaten only a few times during a particular season would Also be checked "never". Foods eaten only a few times during the week or eaten a few times on the weekend would be checked "2-4 times a week". A food eaten more than once a day would checked "2-3 times a day" or " $4+$ times a day" depending on your eating pattern.

If you cannot estimate your usual intake of the food for any reason, leave the item blank.

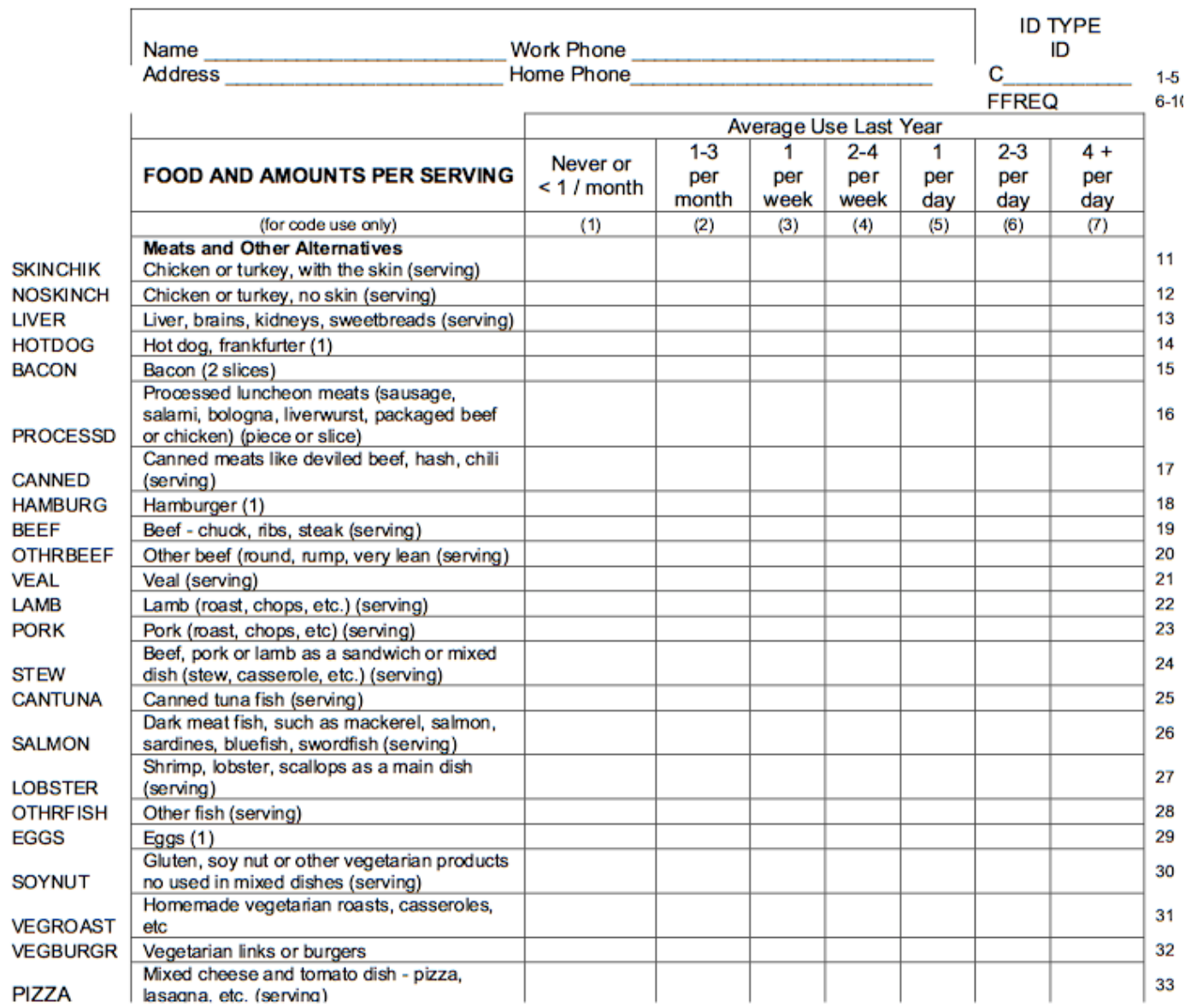




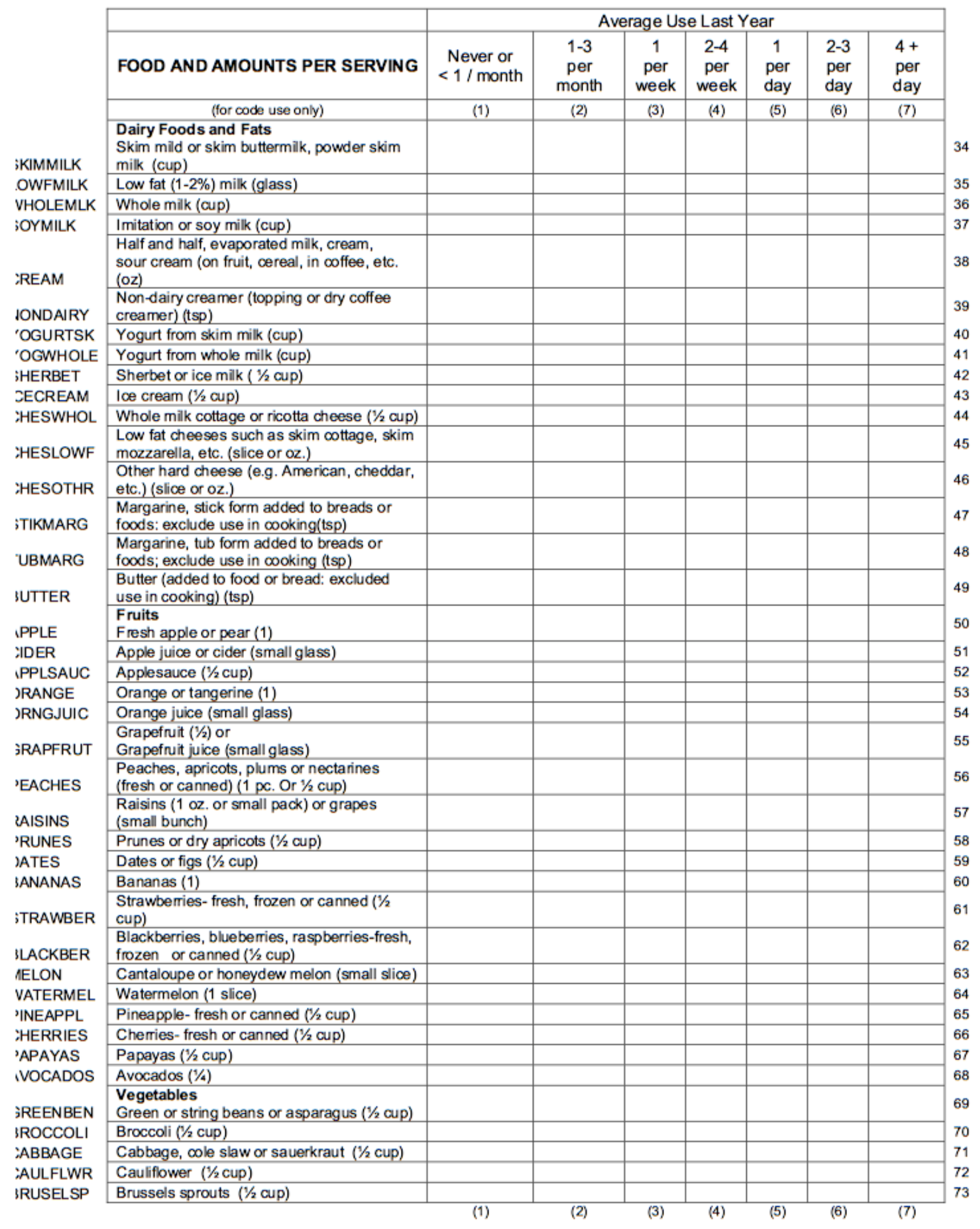




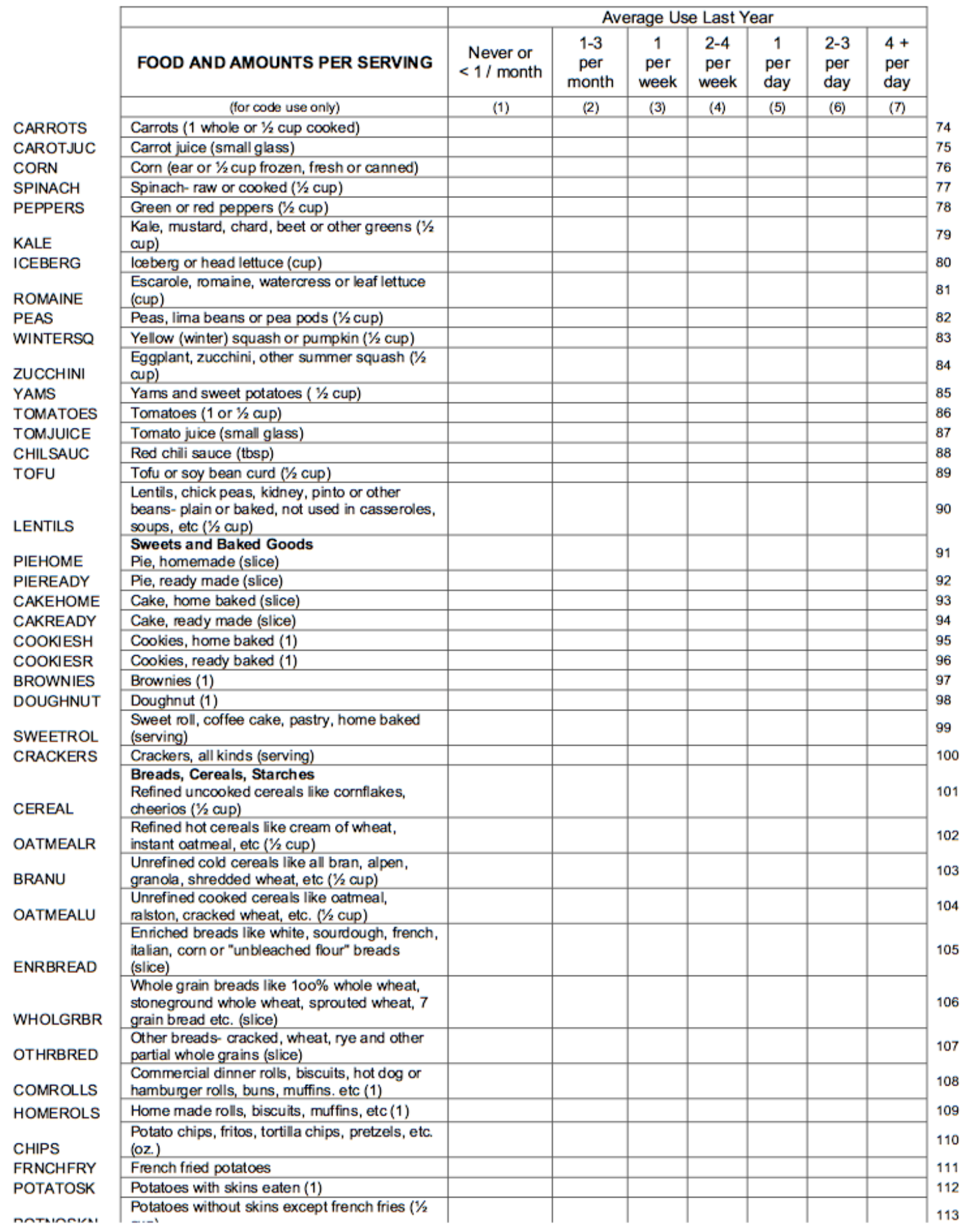




\begin{tabular}{|c|c|c|c|c|c|c|c|c|}
\hline \multirow{8}{*}{$\begin{array}{l}\text { TURNIPS } \\
\text { PANCAKES } \\
\text { BRWNRICE } \\
\text { WHITRICE } \\
\text { PASTA }\end{array}$} & & \multicolumn{7}{|c|}{ Average Use Last Year } \\
\hline & FOOD AND AMOUNTS PER SERVING & $\begin{array}{l}\text { Never or } \\
<1 / \text { month }\end{array}$ & $\begin{array}{c}1-3 \\
\text { per } \\
\text { month }\end{array}$ & $\begin{array}{c}1 \\
\text { per } \\
\text { week }\end{array}$ & $\begin{array}{c}2-4 \\
\text { per } \\
\text { week }\end{array}$ & $\begin{array}{c}1 \\
\text { per } \\
\text { day }\end{array}$ & $\begin{array}{l}2-3 \\
\text { per } \\
\text { day }\end{array}$ & $\begin{array}{l}4+ \\
\text { per } \\
\text { day }\end{array}$ \\
\hline & (for code use only) & (1) & (2) & (3) & (4) & (5) & (6) & (7) \\
\hline & Parsnips and turnips ( $1 / 2$ cup) & & & & & & & \\
\hline & Pancakes or waffles or french toast (slice) & & & & & & & \\
\hline & Brown rice (cup) & & & & & & & \\
\hline & White rice (cup) & & & & & & & \\
\hline & Pasta (spaghetti, noodles, etc) (cup) & & & & & & & \\
\hline OTHRGRAN & $\begin{array}{l}\text { Other grains, e.g. bulger, kasha, barley, } \\
\text { couscous (cup) }\end{array}$ & & & & & & & \\
\hline COFFEE & $\begin{array}{l}\text { Beverages } \\
\text { Coffee (cup) }\end{array}$ & & & & & & & \\
\hline TEA & Tea (cup) & & & & & & & \\
\hline $\mathrm{COCOA}$ & Cocoa (cup) & & & & & & & \\
\hline DECAFCOF & $\begin{array}{l}\text { Decaffeinated coffee, herbal tea, or Postum } \\
\text { (cup) }\end{array}$ & & & & & & & \\
\hline CAFPEPSI & $\begin{array}{l}\text { Caffeinated beverages like Pepsi, Coke, etc } \\
\text { (glass or can) }\end{array}$ & & & & & & & \\
\hline PEPSIFRE & $\begin{array}{l}\text { Decaffeinated beverages like Pepsi-free, } 7 \\
\text { Up, Ginger ale, Root Beer, etc (glass or can) }\end{array}$ & & & & & & & \\
\hline DIETPEPS & $\begin{array}{l}\text { Caffeinated low-calorie beverages like Diet } \\
\text { Pepsi, Diet Coke, etc. (glass or can) }\end{array}$ & & & & & & & \\
\hline DPEPSFRE & $\begin{array}{l}\text { Decaffeinated low-calorie beverages like Diet } \\
\text { Pepsi-free, Diet } 7 \text { Up, Diet ginger ale, etc } \\
\text { (glass or can) }\end{array}$ & & & & & & & \\
\hline BEER & Beer (bottle or can) & & & & & & & \\
\hline REDWINE & Red wine or sherry (glass) & & & & & & & \\
\hline WITEWINE & White wine (glass) & & & & & & & \\
\hline LIQUOR & Liquor or cordial (1 shot) & & & & & & & \\
\hline LEMONADE & $\begin{array}{l}\text { Hawaiian punch, lemonade, or not } \\
\text { carbonated fruit drinks (glass of can) }\end{array}$ & & & & & & & \\
\hline PEANTBUT & $\begin{array}{l}\text { Miscellaneous } \\
\text { Peanut butter (tbsp) }\end{array}$ & & & & & & & \\
\hline POPCORN & Popcorn (cup) & & & & & & & \\
\hline CHOWDER & Chowder or cream soup (cup) & & & & & & & \\
\hline BROTH & Broth soup (cup) & & & & & & & \\
\hline SALDDRES & $\begin{array}{l}\text { Mayonnaise or creamy salad dressing } \\
\text { including } 1000 \text { island, russian, creamy } \\
\text { italian, blue cheese dressing (tbsp) }\end{array}$ & & & & & & & \\
\hline OIL & $\begin{array}{l}\text { Oil-Corn, soy, sunflower etc. except olive oil } \\
\text { (tbsp) }\end{array}$ & & & & & & & \\
\hline OLIVEOIL & Olive oil (tbsp) & & & & & & & \\
\hline SEEDS & Seeds like sunflower seeds, etc. (oz) & & & & & & & \\
\hline WALNUTS & Walnuts (5) & & & & & & & \\
\hline NUTSSALT & Other Salted nuts (oz) & & & & & & & \\
\hline NUTSUNSL & Other unsalted nuts (oz) & & & & & & & \\
\hline CUSTARD & Custard ( $1 / 2$ cup) & & & & & & & \\
\hline PUDDING & Pudding ( $1 / 2$ cup) & & & & & & & \\
\hline CHOCOLAT & Chocolate (small bar) & & & & & & & \\
\hline OTHRCNDY & Candy without chocolate (small bar) & & & & & & & \\
\hline JAMS & Jams, jellies, preserves, syrup (tbsp) & & & & & & & \\
\hline WHEATGRM & Wheat germ (tsp) & & & & & & & \\
\hline YEAST & Brewer's Yeast (tsp) & & & & & & & \\
\hline BRAN & Bran (tsp) & & & & & & & \\
\hline WHITSAUC & White or cream sauces (tbsp) & & & & & & & \\
\hline TOMSAUC & Tomato sauce (tbsp) & & & & & & & \\
\hline GRAVY & Gravy-made from meat (tbsp) & & & & & & & \\
\hline SUGAR & Sugar of honey (tsp) & & & & & & & \\
\hline
\end{tabular}




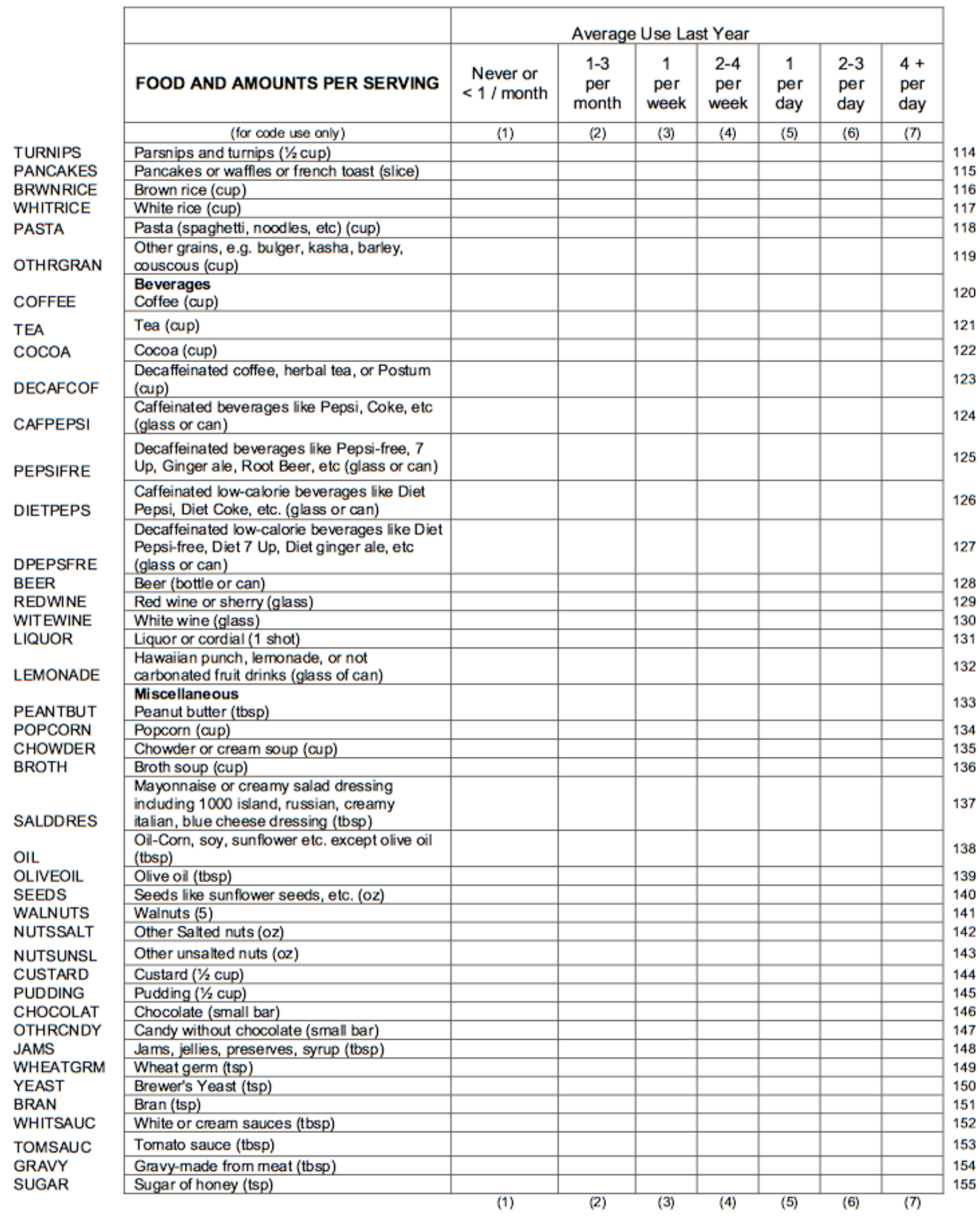


Appendix 20.

Godin Leisure-Time Exercise Questionnaire

\section{Godin Leisure-Time Exercise Questionnaire}

During a typical 7-Day period (a week), how many times on the average do you do the following kinds of exercise for more than $\mathbf{1 5}$ minutes during your free time (write on each line the appropriate number).

Weekly leisure activity score $=(9 \times$ Strenuous $)+(5 \times$ Moderate $)+(3 \times$ Light $)$

\begin{tabular}{|c|c|c|c|}
\hline & $\begin{array}{l}\text { Times per } \\
\text { week }\end{array}$ & & Totals \\
\hline $\begin{array}{l}\text { a) STRENUOUS EXERCISE } \\
\text { (HEART BEATS RAPIDLY) } \\
\text { (e.g,, running, jogging, hockey, football, soccer, squash, } \\
\text { basketball, cross country skiing, judo, roller skating, } \\
\text { vigorous swimming, vigorous long distance bicycling) }\end{array}$ & & X9 & \\
\hline $\begin{array}{l}\text { b) MODERATE EXERCISE } \\
\text { (NOT EXHAUSTING) } \\
\text { (e.g, fast walking, baseball, tennis, easy bicycling, } \\
\text { volleyball, badminton, easy swimming, alpine skiing, } \\
\text { popular and folk dancing) }\end{array}$ & & $\mathbf{X 5}$ & \\
\hline $\begin{array}{l}\text { c) MILD/LIGHT EXERCISE } \\
\text { (MINIMAL EFFORT) } \\
\text { (e.g, yoga, archery, fishing from river bank, bowling, } \\
\text { horseshoes, golf, snow-mobiling, easy walking) }\end{array}$ & & $\mathbf{X} 3$ & \\
\hline WEEKLY LEISURE-TIME ACTIVITY SCORE & & & \\
\hline
\end{tabular}

EXAMPLE

Strenuous $=\mathbf{3}$ times $/ \mathrm{wk}$

Moderate $=6$ times $/$ wk

Light $=14$ times $/$ wk

Total leisure activity score $=(9 \times 3)+(5 \times 6)+(3 \times 14)=27+30+42=99$

\begin{tabular}{|l|l|}
\hline Godin Scale Score & Interpretation \\
\hline 24 units or more & Active \\
\hline $14-23$ units & Moderately Active \\
\hline Less than 14 units & Insufficiently Active/Sedentary \\
\hline
\end{tabular}

Adapted from: Godin, G. (2011). The Godin-Shephard leisure-time physical activity questionna ire. Heaith $\nsim$ Fit ness Journal of Canada, 4(1), 18-22.

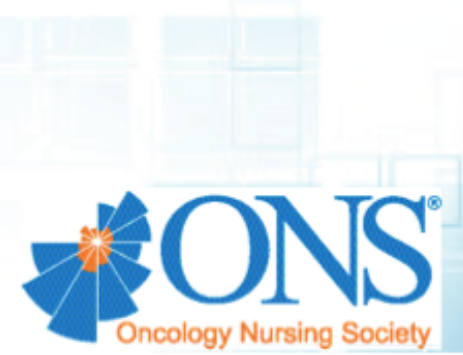


VITA

\section{ABEER HUSSAIN ALSSAFI}

Born, Riyadh, Saudi Arabia

2010

B.A., King Saud University

Riyadh, Saudi Arabia

2014

M.S., Florida International University

Miami, Florida

2018

P.h.D., Florida International University

Miami, Florida

\section{POSTERS AND PRESENTATIONS}

- Alssafi, A.H., Krishnakumar, P., Gonzalez-Rebull, E., and Coccia, CC. (October, 2018). Development of a Social Media-Based Intervention for Preventing Weight Gain among Female College Students. Poster presented at the Food \& Nutrition Conference \& Expo, Washington, D.C.

- $\quad$ Earle, S., Matthysse, A., Alssafi, A.H., Lara-Gonzale, C., and Coccia, C.C. (October, 2018). Urban Vegetable Project 2: Changing Knowledge and Health Behaviors in Adolescents. Poster presented at the Food \& Nutrition Conference \& Expo, Washington, D.C.

- Maria, D.S., Alssafi, A.H., and Coccia, C.C. (October, 2017). The Food Selfie Project: Eating Behaviors of Dietetic Students Through the Use of Instagram. Poster presented at the Food \& Nutrition Conference \& Expo, Chicago, IL.

- Alssafi, A., Aldaghri, N.M., and Huffman, F.G. (April, 2015). Determine vitamin $D$ deficiency in Saudi Arabian subjects: Relationship to dietary vitamin D and calcium intake, body mass index, physical activity, and exposure to sun. Poster presented at the Future of Food and Nutrition, Boston, MA. 